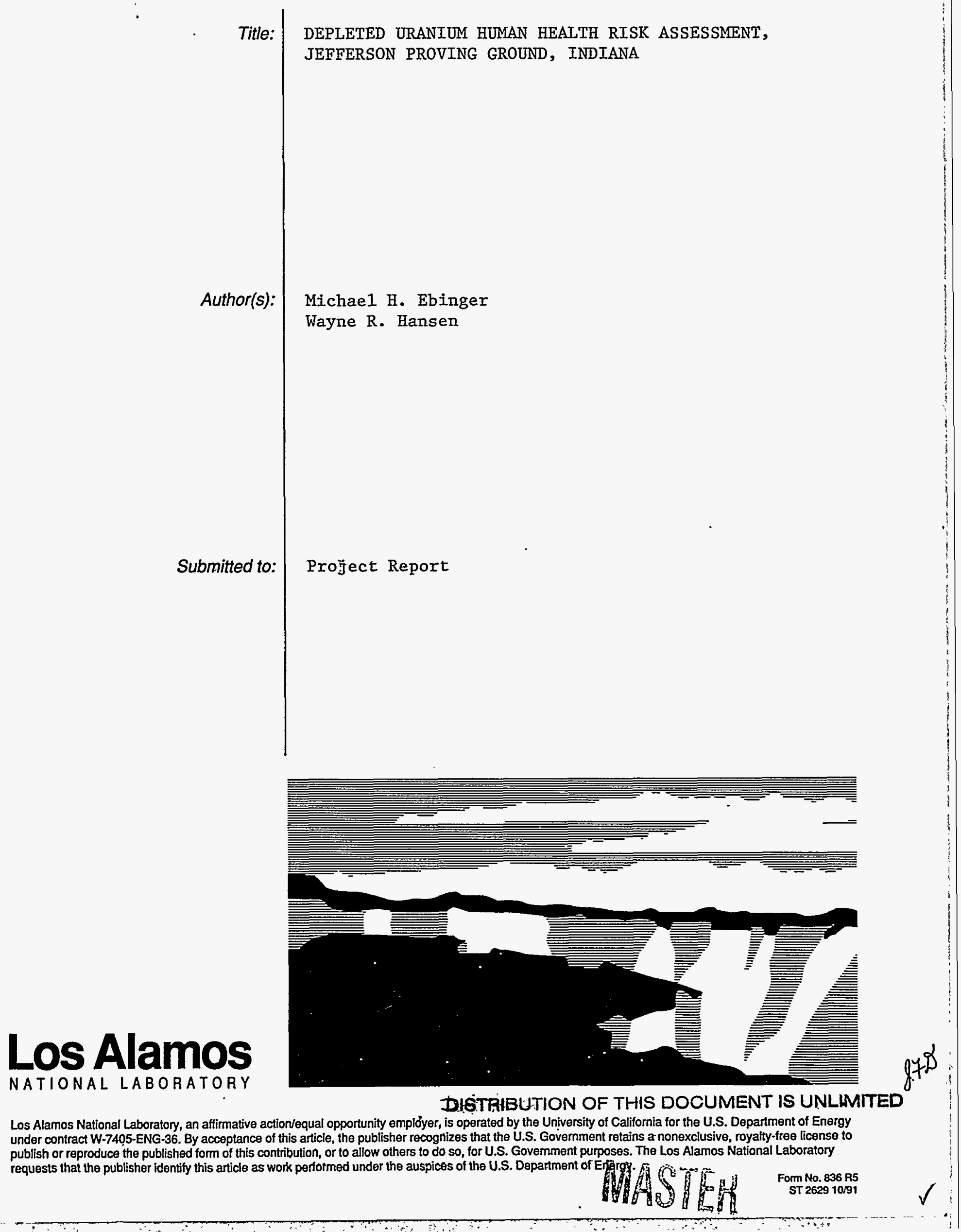




\section{DISCLAIMIER}

Portions of this document may be illegible in electronic image products. Images are produced from the best available original document. 


\title{
Depleted Uranium Human Health Risk Assessment, Jefferson Proving Ground, Indiana
}

\author{
Michael H. Ebinger \\ $\&$ \\ Wayne R. Hansen
}

Environmental Science Group

Los Alamos National Laboratory

- Prepared for Test and Evaluation Command, U. S. Army, Aberdeen Proving, Ground, Maryland

April 29, 1994

\section{DISCLAIMER}

This report was prepared as an account of work sponsored by an agency of the United States Government. Neither the United States Government nor any agency thereof, nor any of their employees, makes any warranty, express or implied, or assumes any legal liability or responsibility for the accuracy, completeness, or usefulness of any information, apparatus, product, or process disclosed, or represents that its use would not infringe privately owned rights. Reference herein to any specific commercial product, process, or service by trade name, trademark, manufacturer, or otherwise does not necessarily constitute or imply its endorsement, recommendation, or favoring by the United States Government or any agency thereof. The views and opinions of authors expressed herein do not necessarily state or reflect those of the United States Government or any agency thereof. 


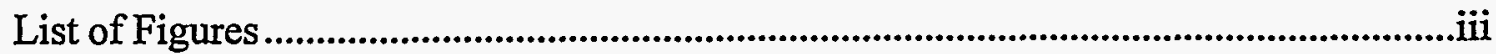

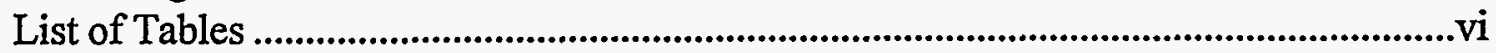

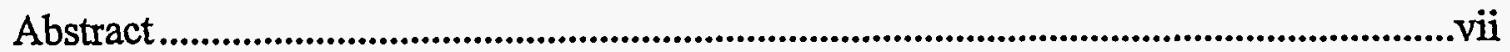

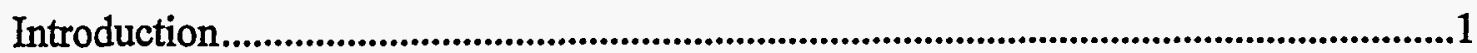

JPG Environment-.-Overview...................................................................................2

Exposure Models .................................................................................................................

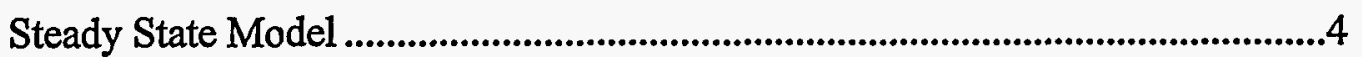

Sensitivity and Uncertainty Analyses ....................................................8

RESRAD Model .................................................................................................17

Hunting or Occasional Use Scenario .........................................................19

Resident Farming Scenario \#1 .....................................................................23

Resident Farming Scenario \#2 .................................................................25

Doses to Humans Estimated from Models.............................................................29

Estimated Risk Calculated from Doses..................................................................35

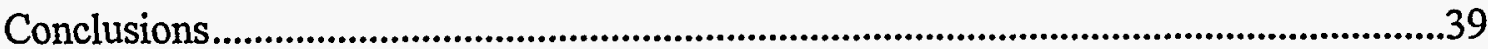

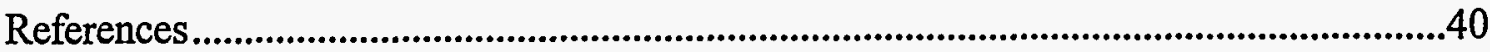

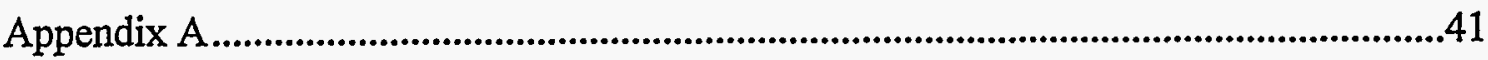

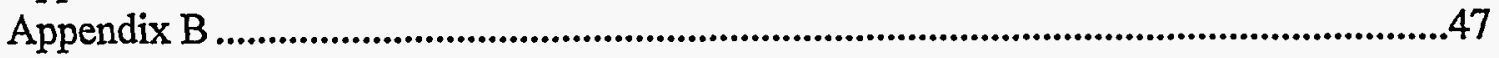




\section{LIST OF FIGURES}

Figure 1. Schematic diagram of steady-state model. Source is DU deposited in soil; arrows indicate DU migration from one component to another

Figure 2. Frequency distribution of DU concentrations in deer tissue, $C_{i}$, calculated from the steady-state model. The distribution of $\mathrm{C}_{\mathrm{i}}$ values was obtained from 10,000 simulations of Equation 1. Values for the parameters were randomly selected from their own distributions for each simulation.

Figure 3. Standard deviations of calculated $\mathrm{C}_{\mathrm{i}}$ values when only plant consumption, soil ingestion, or water consumption pathways were varied in the model. Soil ingestion pathway showed the largest standard deviation and thus is the most sensitive parameter under the conditions of this simulation

Figure 4. Mean, median, and mode of $\mathrm{C}_{\mathrm{i}}$ for the three pathways in the steady-state model. $\mathrm{C}_{\mathrm{i}}$ was calculated with Equation 1 by varying either water, soil, or plant uptake. Simlutions were for 10,000 iteration with Equation 1

Figure 5. Distribution of DU concentrations in deer tissue, $C_{\mathfrak{i}}$, if uniform concentration of DU fragments is assumed for entire impact area. Simulation conditions were

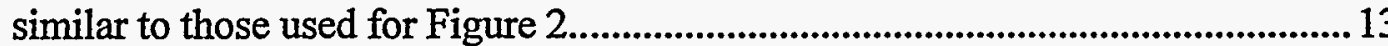

Figure 6. Standard deviation of $\mathrm{C}_{\mathrm{i}}$ due to variation in the soil ingestion pathway parameters only. The actual standard deviations are given above each bar. Values were obtained by allowing only one parameter, $Q_{S}$ or $C_{S}$, to vary during 10,000 simulations, then repeating the simulations letting the other parameter vary .........15

Figure 7. Standard deviations of $\mathrm{C}_{\mathrm{i}}$ due to variation in water consumption pathway parameters. The actual standard deviations are given above each bar. Values were obtained by allowing only one parameter to vary and holding the others constant during 10,000 simulations, then repeating the simulations letting the other parameters vary one at a time.

Figure 8. Standard deviations of $C_{i}$ due to variation in the DU ingested from plant surfaces. The actual standard deviations are given above each bar. Values were obtained by allowing only one parameter to vary and holding the others constant during 10,000 simulations, then repeating the simulations letting the other parameters vary one at a time. 
Figure 9. Dose calculated using RESRAD for all pathways in the hunting and occasional use scenario. Dust loading is the concentration of dust in the air and, therefore, related to the airborne DU concentration. Dust loading is one of the most sensitive parameters in the RESRAD simulations. Nominal dust loading is $200 \mu \mathrm{g} / \mathrm{m}^{3}$ in each RESRAD simulation.

Figure 10. Water-dependent and water-independent contributions to the total dose from the hunting/occasional use scenario. Figure is based on nominal $\left(200 \mu \mathrm{g} / \mathrm{m}^{3}\right)$ dust loading and average soil concentration. Water-dependent dose is low because drinking water was brought in and no on-site produce was consumed

Figure 11. Total dose estimated using DU soil concentration of $35 \mathrm{pCi} / \mathrm{g}$, water concentration of $1 \mathrm{pCi} / \mathrm{l}$, and varying the dust loading. Graph illustrates the importance of actual concentrations of DU in soil and water to dose calculations

Figure 12. Total dose from farming scenario \#1 using average soil concentration. Dust loading is the most sensitive parameter, and the range is the same as in previous figures. Dose to humans is significantly greater than hunting scenario due to longer times on the site and consumption of more produce from the site 24

Figure 13. Water-dependent and water-independent contributions to total dose, farming scenario \#1 and average soil concentration. Dose from water dependent sources is due to consumption of produce, meat, and fish. Dose from water independent pathway is from dust inhalation and irradiation from contaminated soil. Figure based on nominal $\left(200 \mu \mathrm{g} / \mathrm{m}^{3}\right)$ dust loading.

Figure 14. Dose from water-dependent pathways, farming scenario \#1, average soil concentration. Nominal $\left(200 \mu \mathrm{g} / \mathrm{m}^{3}\right)$ dust loading used for this figure. 26

Figure 15. Total dose, farming scenario \#1, assuming $35 \mathrm{pCi} / \mathrm{g}$ soil and water concentrations of $1 \mathrm{pCi} / \mathrm{L} \mathrm{DU}$ across the site 27

Figure 16. Water dependent and water independent contributions to total dose farming scenario \#1. Soil concentration of $35 \mathrm{pCi} / \mathrm{g}$ and water concentration of $1 \mathrm{pCi} / 1$ were assumed throughout the site as in Figure 15. Nominal dust loading used for this graph

Figure 17. Total dose, farming scenario \#2, average soil concentration and $1 \mathrm{pCi} / 1$ in water. Dust loading range same as in previous figures

Figure 18. Water dependent contributions to total dose, farming scenario \#2, average soil concentration and $1 \mathrm{pCi} / \mathrm{l}$ in water. Nominal $\left(200 \mu \mathrm{g} / \mathrm{m}^{3}\right)$ dust loading used for this figure. Total dose dominated by the contributions from fish concumption and drinking water. Compare to Figure 14. 
Figure 19. Water-dependent and water-independent contributions to total dose, farming scenario \#2, average soil concentration and $1 \mathrm{pCi} / \mathrm{l}$ in water. Nominal $\left(200 \mu \mathrm{g} / \mathrm{m}^{3}\right)$ dust loading used.

Figure 20. Total dose assuming soil concentration of $35 \mathrm{pCi} / \mathrm{g}$ and water concentration of $1 \mathrm{pCi} / 1$ across the site, farming scenario \#2. Nominal dust loading used for this graph

Figure 21. Contributions from water-dependent pathways to total dose based on soil concentration of $35 \mathrm{pCi} / \mathrm{g}$ and water concentration of $1 \mathrm{pCi} / \mathrm{l}$. Dose is dominated by fish and water consumption with relatively small contributions from different pathways

Figure 22. Water-dependent and water-independent contributions to total dose assuming soil concentration of $35 \mathrm{pCi} / \mathrm{g}$ and water concentration of $1 \mathrm{pCi} / \mathrm{l}$, farming scenario \#2. The large contribution from the water dependent pathway is due to consumption of fish and drinking water at the site and DU transfer to produce, meat, and milk

Figure 23. Contribution of deer meat and all other produce to human dose for the hunting scenario. Graph based on nominal $\left(200 \mu \mathrm{g} / \mathrm{m}^{3}\right)$ dust loading and average soil concentrations.

Figure 24. Contributions to human dose from exposure to contaminated soil, direct inhalation, and consumption of deer meat. Graph based on nominal $\left(200 \mu \mathrm{g} / \mathrm{m}^{3}\right)$ dust loading and average soil concentrations 


\section{LIST OF TABLES}

Table 1. Selected statistics from Monte Carlo simulation of DU in deer tissue, $C_{\mathbf{i}}$. See Also Figure 2

Table 2. Selected statistics from Monte Carlo simulation of DU in deer tissue, $C_{\mathbf{i}}$. Entire impact area used as area of resuspension. See also Figure 5

Table 3. Range, mean, and standard deviations for soil and water concentrations from Abbott et al (1983). Concentrations are ${ }^{238} \mathrm{U}$ and ${ }^{234} \mathrm{U}$ activities as $\mathrm{pCi} / \mathrm{g}$ or $\mathrm{pCi} / \mathrm{L}$.

Table 4. Dose conversion factors for ${ }^{238} \mathrm{U}$ and ${ }^{235} \mathrm{U}(\mathrm{DCF} U$, rem/Ci) and tissue weighting factors $\left(\mathrm{W}_{t}\right)$ used for calculating human doses and detriment due to radiation.

Table 5. Estimated human dose from consumption of deer tissue, steady-state model. Doses for all but CEDE include appropriate tissue weighting factor (ICRP 60, 1990).......33

Table 6. Annual doses (mrem/y) from all pathways calculated from RESRAD model scenarios. Annual dose is based on CEDE and is shown for each year of the simulations. Doses for average and $35 \mathrm{pCi} / \mathrm{g}$ soil and water concentrations given

Table 7. Conversion of annual doses to annual detriments in adult workers and the whole population from the steady-state model. Detriments are tabulated below as $10^{-7}$ detriments per year, and are a sum of fatal cancers, non-fatal cancers, and severe hereditary effects. Conversion based on $1 \times 10^{-2}$ detriments/Sv or $1 \times 10^{-7}$ detriments/mrem (ICRP, 1990)

Table 8. Excess cancer risks based on doses in Table 6. Excess cancers are tabulated as $10^{-5}$ or $10^{-6}$ cancers per year from all pathways. Exposed individual is the site user or site resident. 


\begin{abstract}
The risk to human health from fragments of depleted uranium (DU) at Jefferson Proving Ground (JPG) was estimated using two types of ecosystem pathway models. A steady-state model of the JPG area was developed to examine the effects of DU in soils, water, and vegetation on deer that were hunted and consumed by humans. The RESRAD code was also used to estimate the effects of farming the impact area and consuming the products derived from the farm. The steady-state model showed that minimal doses to humans are expected from consumption of deer that inhabit the impact area. Median values for doses to humans range from about 1 mrem $( \pm 2.4)$ to 0.04 mrem ( \pm 0.13 ) and translate to less than $1 \times 10^{-6}$ detriments (excess cancers) in the population. Monte Carlo simulation of the steady-state model was used to derive the probability distributions from which the median values were drawn. Sensitivity analyses of the steady-state model showed that the amount of DU in airborne dust and, therefore, the amount of DU on the vegetation surface, controlled the amount of DU ingested by deer and by humans. Human doses from the RESRAD estimates ranged from less than $1 \mathrm{mrem} / \mathrm{y}$ to about $6.5 \mathrm{mrem} / \mathrm{y}$ in a hunting scenario and subsistence farming scenario, respectively. The human doses exceeded the 100 $\mathrm{mrem} / \mathrm{y}$ dose limit when drinking water for the farming scenario was obtained from the on-site aquifer that was presumably contaminated with $D U$. The two farming scenarios were unrealistic land uses because the additional risk to humans due to unexploded ordnance in the impact area was not figured into the risk estimate. The doses estimated with RESRAD translated to less than $1 \times 10^{-6}$ detriments to about $1 \times 10^{-3}$ detriments. The higher risks were associated only with the farming scenario in which drinking water was obtained on-site.
\end{abstract}




\section{INTRODUCTION}

The purpose of this report is to estimate the human health risk of DU fragments in the environment at Jefferson Proving Ground (JPG), Indiana. Supporting information for the risk assessment is site-specific environmental monitoring data, knowledge of testing programs that occurred there, and personal knowledge of the site related by those who work there regularly. The goals of this project were to show that the JPG environmental data can be used satisfactorily for risk assessments if the data are collected according to a well designed sampling plan; to estimate the human health risks of DU fragments from munitions testing left in the environment after closure of JPG; and to test ecosystem models developed for the DU risk assessment at Aberdeen Proving Ground (APG) against data from a site in a slightly different climate but with similar deposition of DU fragments. This study was not supplemented with environmental sampling specifically designed to obtain data for a risk assessment.

The environmental data and knowledge of JPG DU impact areas available for this risk assessment is an important resource. The main source of environmental data is a summary report of the environmental radiation monitoring plan (Abbott et al, 1983) and the environmental data collected to 1989. Important information was given to us by Mr. Richard Herring about the occurrence of different animals in the impact area as well as some of the peculiarities of the DU deposition in the impact area.

The Environmental Monitoring Plan (ERM) data include information on DU concentrations in aquatic and terrestrial animals, water and soils, and human urine samples collected from workers on the impact area. The summary report also discusses relevant geological, hydrological, and soil morphology of JPG, and resulted in more reliable estimates of parameters related to contaminant-environment interactions. The values used in the modeling discussed below are tabulated in Appendices A and B, whereas the entire ERM data set is given elsewhere (Abbott et al, 1983).

Two models were developed for this risk assessment. A steady-state model was used to estimate the DU transfer to deer and to humans via consumption of deer tissue. A risk 
assessment program written for DOE applications, RESRAD, was also used for this risk assessment. Briefly, RESRAD estimated the human health risk of specific contaminants and uses site-specific parameters supplied by the user. RESRAD gives the broadest look at contaminant transfer to humans, but has less emphasis on the ecological risk of the same contaminants.

Estimates of doses and/or risks derived from the models are of limited value unless the uncertainty in the estimates are also given. Uncertainty in the estimates arises from variation in the input parameters for each model and from conceptual inadequacies of any model. The data cited throughout this report show variation from one time to the next or from one sample to the next at a given time. Thus, the values used in the model estimates are not point estimates but probability distributions based on the range and expected values reported in the ERM data. The natural variation of the data was incorporated in the modeling conducted for this risk assessment.

The sensitivity of different models or parts of models is related to uncertainty. We needed to know which parameters most affected the estimated DU concentration or risk estimates calculated by each model in order to better understand and quantify model uncertainty. Sensitivity information helped identify those parameters or processes that could result in significant change in the risk estimates if the values for those parameters is under- or overestimated. Sensitivity analyses for each model will be presented as will the methodology for determining both sensitivity and uncertainty.

JPG Environment--Overview

The environment at JPG is characterized by deciduous forests incised by several surface streams and rivers, and aquatic and terrestrial biota supported by the forests. Rainfall averages about 37 inches annually with most precipitation in the winter and spring. Average yearly temperature is about $50^{\circ} \mathrm{F}$ and the mean monthly temperatures range from about $31^{\circ}$ to $76^{\circ} \mathrm{F}$.

The surface geology of JPG is dominated by Quaternary glacial activity. Glacially altered deposits generally overlie limestone bedrock, and the bedrock is exposed in some areas, 
especially in stream channels. Soils tend to have fragipans owing to development in loess deposits under slightly acidic conditions since the last (Wisconsin) glaciation. Surface water is mainly in streams and rivers that incise JPG and flow from NE to SW, and there are several small ponds and two larger lakes on the JPG reservation. Surface water collects and conveys runoff from the site and includes runoff from agricultural lands that surround most of JPG. Surface waters also support populations of aquatic and terrestrial animals including white-tailed deer, raccoons, cottontail rabbit, foxes, small- and large-mouth bass, crappie, carp, and a diversity of birds. Groundwater at JPG is generally found close to the surface and tends to be found near the contact with the limestone bedrock. Depths from the surface to bedrock from several test wells on the site ranged from about 5 feet to about 27 feet, and water tables were observed in the same wells at approximately the same depths as the contact with bedrock. Utilization of game animals (i.e., birds, fish, and mammals) occurs and is an important pathway to investigate for potential DU transfer to humans. More detailed discussion of the JPG environment before and since DU testing is found in the JPG environmental review (Abbott et al, 1983).

\section{EXPOSURE MODELS}

The most time-efficient and systematic means of estimating the effects of contaminants on ecosystems and/or humans is to develop mathematical models that describe the interactions between organisms in a particular environment. The organisms described by a model are considered compartments or components of the model. The purpose of models is to understand the flow of a contaminant, in this case depleted uranium, through the compartments of the system.

In the following sections two modeling approaches are described, discussed, and the results from using the models are presented. These approaches are 1) steady-state, and 2) detailed environmental pathway analysis. The steady-state model requires the least amount of data and can be used even when several parameters are estimated. The environmental pathway 
approach quantifies the interactions between compartments more realistically and demands more complete knowledge of the system being studied. The pathway approach also affords the program user a more detailed examination of the interactions between compartments, thereby making it possible to know more about contaminant transfer throughout the system of interest. Each approach used in the risk assessment of DU at JPG will be presented below.

\section{Steady-State Model}

The steady-state model was based on the two-component, steady-state model described by the NCRP (NCRP, 1984). The NCRP model was developed for estimating radionuclide uptake by plants and animals in the vicinity of nuclear power plants and includes intake of radionuclides by animals grazing from foliar surfaces and from radionuclides internally deposited in the plants. The NCRP model was readily adapted for use in the JPG risk assessment by including a term for soil ingestion by animals, changing the animal of interest from cattle to deer, modifying the feed and water intake rates accordingly, and including the transfer of DU to man by way of consumption of deer tissue. Figure 1 is the schematic of the JPG steady-state model.

DU transfer between system compartments is quantified in Equation 1:

$$
C_{i}=F_{a}\left[\left(C_{a}+C_{d}\right) f_{p} f_{f} Q_{f}+f_{s} C_{s} Q_{s}+C_{w} f_{w} Q_{w}\right]
$$

where $C_{i}$ is the concentration of DU in deer tissue, $F_{a}$ is the transfer coefficient from ingested DU to deer tissue, $C_{a}$ is the DU concentration that passes into plant roots from soil and is incorporated in the plant tissue, $C_{d}$ is the $D U$ concentration deposited on the surface of plants eaten by deer, $f_{p}$ is the fraction of time deer spend on the contaminated area, $f_{\mathrm{f}}$ is the fraction of the fodder supply that is contaminated, $Q_{f}$ is the consumption rate of vegetation by deer, $f_{s}$ is the fraction of the ingested soil that is contaminated with DU, $C_{s}$ is the DU concentration in the soil, 


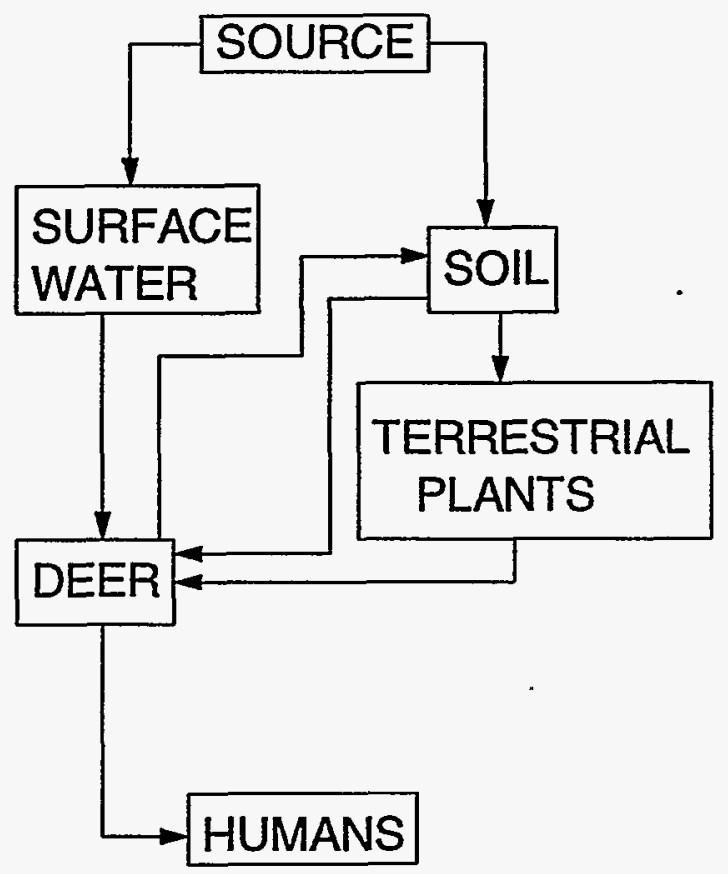

Figure 1. Schematic diagram of Steady-State Model. Source is DU deposited in soil, arrows indicate DU migration from one component to another. 
$\mathrm{Q}_{\mathrm{S}}$ is the soil ingestion rate by deer, $\mathrm{C}_{\mathrm{W}}$ is the DU concentration in water drunk by deer, $\mathrm{f}_{\mathrm{W}}$ is the fraction of the water that is contaminated, and $\mathrm{Q}_{\mathrm{W}}$ is the consumption rate of water by deer. The term $\mathrm{f}_{\mathrm{S}} \mathrm{C}_{\mathrm{S}} \mathrm{Q}_{\mathrm{S}}$ describes the soil ingestion component of $\mathrm{C}_{\mathrm{i}}$, the $\mathrm{C}_{\mathrm{w}} \mathrm{f}_{\mathrm{w}} \mathrm{Q}_{\mathrm{W}}$ term describes the water ingestion component of $\mathrm{C}_{\mathrm{i}}$, and the remaining term describes the contribution of DU from plants. The DU concentration in plant tissue, $\mathrm{C}_{\mathrm{a}}$, is calculated by Equation 2 as

$$
C_{a}=\frac{B_{1} d}{p}\left(\frac{1-\exp \left(-\lambda_{1} t_{b}\right)}{\lambda_{1}}\right)
$$

where $d$ is the estimated deposition rate from air, $B_{1}$ is the bioconcentration factor for soil to plants (NCRP 1984), $\mathrm{P}$ is the soil bulk density within the plow layer, $\lambda_{1}$ is the removal rate or leaching rate of DU from the soil, and $t_{b}$ is the time the DU accumulates in the contaminated area. The deposition rate from air is the amount of DU that is deposited after a penetrator impacts contaminated soil and lifts the soil into the air. Ambient winds also result in resuspended DU but at lower frequncy than resuspension from penetrator impacts. The deposition amount and rate depend on the soil concentration of DU in the area where the penetrators impact and on the amount of DU in particles small enough to be transported in the air. From measurements and field observations at APG, only a fraction of the total inventory is available for transport by resuspension because some of the fragments are deposited in areas of infrequent impact, and some fragments are too large to be deposited on plant surfaces.

We used data from YPG (Price, 1991) and APG to estimate probable locations within the JPG impact areas that would result in the largest surface deposition rate and therefore the largest DU deposition on plant surfaces. The location at YPG that is most likely to result in large values of $\mathrm{d}$ is at about $2500 \mathrm{~m}$ downrange from GP 17A (Price, 1991, Appendix A). Assuming that the impact area of GP 17A is as indicated in Price's Appendix A (Price, 1991), then the area of greatest concentration is conservatively, estimated at $5 \%$ of the total impact area. The total DU concentration in the affected area is no greater than about $10 \%$ of the total inventory in the 
environment. Using this information, the deposition rate was calculated by taking the fraction of the total inventory that is available for redistribution and dividing it by the amount of area that is available for deposition. DU recovery data from APG showed that there are two areas that could be most susceptible to conditions favoring resuspension of small particles.

The DU removal rate in Equation 2 is defined by Equation 3 as

$$
\lambda_{1}=\lambda_{t}+\lambda_{L}+\lambda_{H}
$$

where $\lambda_{t}$ is the loss of DU due to radioactive decay, $\lambda_{L}$ is the loss of DU due to leaching through the soil, and $\lambda_{\mathrm{H}}$ is loss of DU due to harvest and removal of vegetation from the food supply. Since DU has an extremely long half-life $235 \mathrm{U}=7.1 \times 10^{8}$ years, ${ }^{234} \mathrm{U}=2.5 \times 10^{5}$ years, and ${ }^{238} \mathrm{U}=4.5 \times 10^{9}$ years), the amount of DU lost per unit time (per day in the model) is small and does not contribute significantly to $\lambda_{1}$. There is no harvest or weed removal reported at JPG, except for vegetation consumed by deer and other animals, so the loss rate due to harvest is 0 . Thus, $\lambda_{1}$ depends only on leaching of DU through the soil. A simple leaching model was used (NCRP, 1984; Hoffman and Baes, 1974) and is given as Equation 4:

$$
\lambda_{1}=\lambda_{\mathrm{L}}=\frac{\mathrm{V}_{\mathrm{w}}}{\mathrm{d}_{\mathrm{s}}\left[1+\left(\frac{\rho}{\theta} \mathrm{K}_{\mathrm{d}}\right)\right]}
$$

where $V_{w}$ is the velocity of water percolating downward through the soil, $d_{s}$ is the depth of the root zone, $\rho$ is the soil bulk density, $\theta$ is the volumetric water content of the soil, and $K_{d}$ is the distribution coefficient or the ratio of DU on the soil particles to the DU concentration in the soil water at equilibrium.

The concentration on the surface of foliage, $C_{d}$ in Equation 1, was calculated using Equation 5: 


$$
C_{d}=\frac{f T_{v} d}{Y_{v}} \frac{1-\exp \left(-\lambda_{E} t_{c}\right)}{\lambda_{E}}
$$

where $f_{r}$ is the fraction of the material intercepted by the plant surface, $T_{v}$ is the translocation factor to edible portions of the plant, $d$ is the deposition rate as defined in Equation (2), $Y_{v}$ is the standing plant biomass at the end of the growing season, $\lambda_{E}$ is the removal constant of $D U$ from the plant surface, and $t_{e}$ is the time the plant has been exposed to $D U$ at the rate specified by $d$. $\lambda_{E}$ is calculated using Equation 6 :

$$
\lambda_{E}=\lambda_{t}+\frac{\ln 2}{t_{w}}
$$

where $\lambda_{t}$ is the radioactive half-life as defined in Equation (3) and $t_{w}$ is the time required for onehalf the deposited DU to be lost from the surface of the plant. Since $\lambda_{t}$ (per day) is small with respect to the second term of Equation $6, \lambda_{E}$ is effectively a function only of $t_{w}$. The values, ranges, and statistical distributions of the variables listed in Equations $1-6$ are too numerous to list in this text. Instead, these values are tabulated in Appendix A.

Sensitivity and Uncertainty Analyses. Estimating the DU concentration in deer meat consumed by humans $\left(\mathrm{C}_{\mathfrak{i}}\right.$, Equation 1$)$ also requires estimating the uncertainty or the statistical distribution of $\mathrm{C}_{\mathrm{i}}$. The calculations detailed above were used in a Monte Carlo simulation to show the effects of variation in the input parameters on the estimated DU concentration in deer tissue. The Monte Carlo simulation is an iterative approach to determining the uncertainty in the estimate of $C_{i}$, and assumes that all the parameters are random variables with a probability distribution of values within known ranges. The probability distribution of each of the parameters is also important information used in the Monte Carlo simulation. Each parameter can take on a value within a given range; parameters that are relatively well known will also have information about the distribution of the values for the specific parameter. 
In a Monte Carlo simulation, one value of each parameter in the model (Equation 1 including the contributions from Equations $2-6$ ) is chosen at random from the range and within the probability distribution of that parameter. The chosen values are then used to calculate a single point-estimate of $\mathrm{C}_{\mathrm{i}}$ in Equation 1. After the first calculation, new values are chosen at random for each parameter and a new value of. $C_{\mathbf{i}}$ is calculated. The Monte Carlo simulation continues for any number of iterations.. The important result of the Monte Carlo simulation is a probability distribution of values of $\mathrm{C}_{\mathbf{i}}$. The distribution has an expected value and a characteristic shape that indicates the error or uncertainty in the estimate. Estimates of the uncertainty in $C_{i}$ are better determined as the number of iterations increases.

We used the values and distributions in Appendix A to estimate the uncertainty in the predicted concentration $C_{i}$ (Figure 2 and Table 1). The results of 10,000 iterations were used to generate Figure 2. Table 1 shows that the distribution is positively skewed, indicating that the probability of a value less than the mean is much greater than the probability of a value greater than the mean. The median value of $C_{i}$ in Table 1 shows that there are equal numbers of occurrences above and below $17.1 \times 10^{-3} \mathrm{pCi} / \mathrm{g}$, and the mode shows that the most probable estimate of $C_{i}$ is about $14.2 \times 10^{-3} \mathrm{pCi} / \mathrm{g}$. The standard deviation of the mean is slightly larger than the mean $\left(23.5 \times 10^{-3} \mathrm{pCi} / \mathrm{g}\right)$ and suggests that there is equal probability that an estimated value of $\mathrm{C}_{\mathrm{i}}$ could be 0 or about $50 \times 10^{-3} \mathrm{pCi} / \mathrm{g}$.

Of equal importance is determining the parameters that most influence the estimated values of $\mathrm{C}_{\mathrm{i}}$. Monte Carlo simulation was used to examine those parameters that are the most sensitive. To estimate the sensitivity of the model the parameters were allowed to vary at random within their ranges as they were in the uncertainty analysis. However, only one parameter per simulation was varied while the remaining parameters were held at a fixed value. Ten thousand iterations were run, then the probability distribution was constructed and statistics were calculated for the calculated $\mathrm{C}_{\mathrm{i}}$ 's. One of the statistics, the standard deviation, was one measure of how much variation one parameter caused in the estimated $C_{i}$ 's. A parameter that 


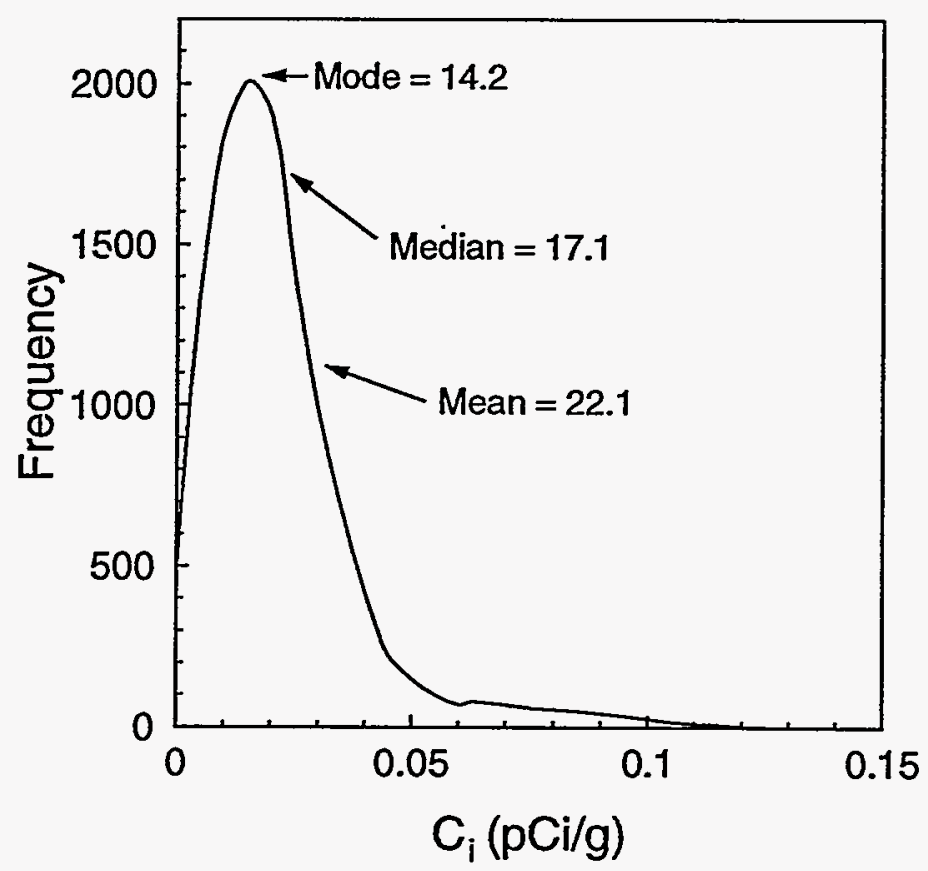

Figure 2. Frequency distribution of DU concentrations in deer tissue, $C_{i}$, calculated from the steady-state model. The distribution of $C_{i}$ values was obtained from 10,000 simulations of Equation 1. Values for the parameters were randomly selected from their own distributions for each simulation. 
Table 1. Selected statistics from Monte Carlo simulation of DU in deer tissue, $\mathrm{C}_{\mathbf{i}}$. See Also Figure 2.

$\begin{array}{ll}\text { Number of Trials } & 10,000 \\ \text { Mean } & 22.1 \\ \text { Median } & 17.1 \\ \text { Mode } & 14.2 \\ \text { Standard Deviation } & 23.5 \\ \text { Range Minimum } & 0 \\ \text { Range Maximum } & 500.0 \\ \text { Skewness } & 6.38\end{array}$

resulted in a large standard deviation about the mean was considered to indicate more sensitivity of the model to that parameter.

Ranking the standard deviations calculated from each Monte Carlo simulation gave the relative sensitivity of the model to variations in parameters. Figure 3 shows that soil ingestion is the most sensitive parameter in the $\mathrm{C}_{\mathrm{i}}$ calculated using Equation 1. The standard deviations for each parameter in Figure 3 were obtained by estimating $C_{i}$ and allowing only the parameter of interest to vary within its range. A large standard deviation indicates more sensitivity of $\mathrm{C}_{\mathrm{i}}$ to variation in the input parameter. Figure 4 shows the mean, median, and mode of $\mathrm{C}_{\mathrm{i}}$ calculated with one of the three paramters varying and the other two held constant. The contributions of soil ingestion and water consumption to $\mathrm{C}_{\mathrm{i}}$ are clearly more dignificant than the contriobution from consumption of vegetation. Table 2 and Figure 5 show the results of $C_{i}$ calculations using all three paramaters simultaneously.

The results of the sensitivity analysis depend on the assumptions about the DU deposition rate as discussed above. If the deposition rate is inaccurately estimated, the amount of DU on plants could significantly alter the $\mathrm{C}_{\mathrm{i}}$ estimates. For instance, if $50 \%$ of the inventory were resuspended from the entire impact area of the site, the values reported in Table 1 would increase, and the importance of ingested plant material would dominate the estimates of $\mathrm{C}_{\mathrm{i}}$. 


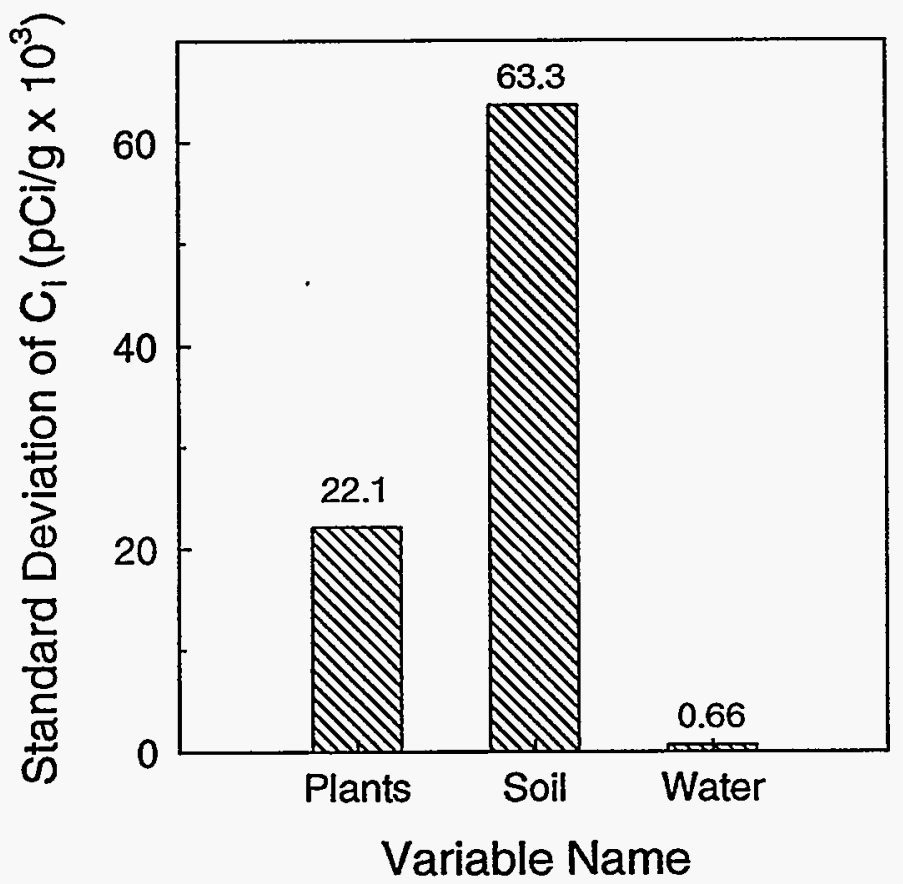

Figure 3. Standard deviations of calculated $C_{i}$ values when only plant consumption, soil ingestion, or water consumption pathways were varied in the model. Soil ingestion pathway showed the largest standard deviation and thus is the most sensitive parameter under the conditions of this simulation.

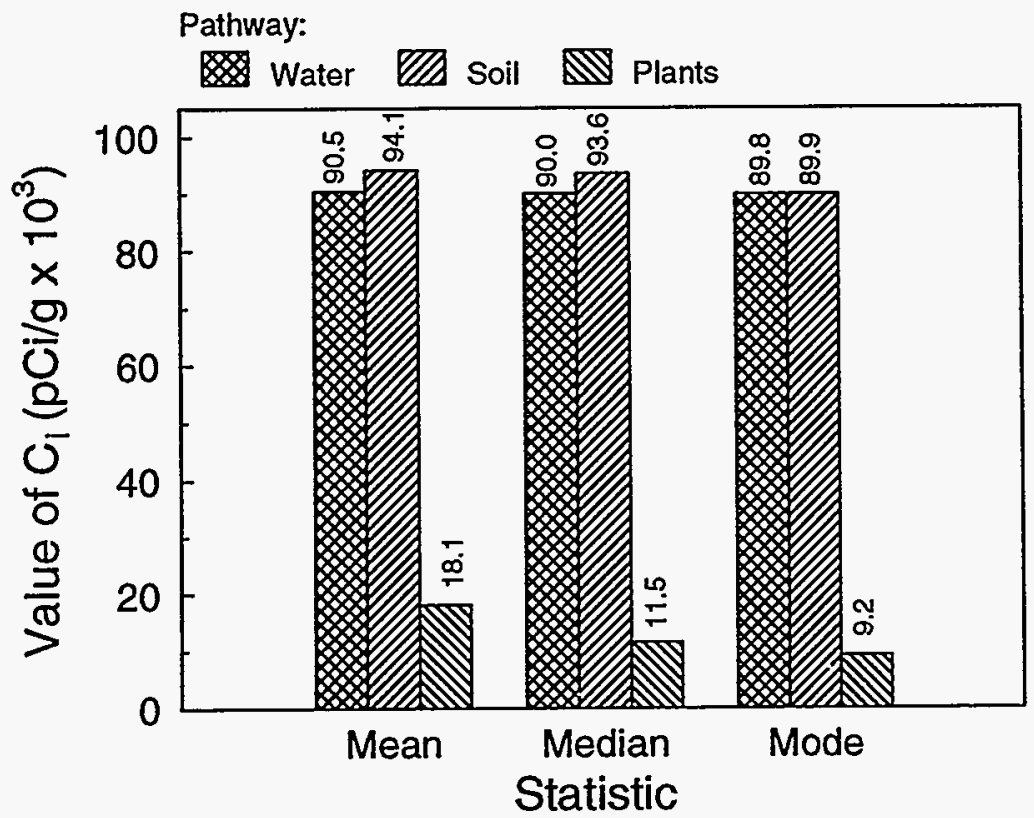

Figure 4. Mean, median, and mode of $C_{i}$ for the three pathways in the Steady-State model. $C_{i}$ was calculated with Equation 1 by varying either water, soil, or plant uptake. Simlutions were for 10,000 iteration with Equation 1. 


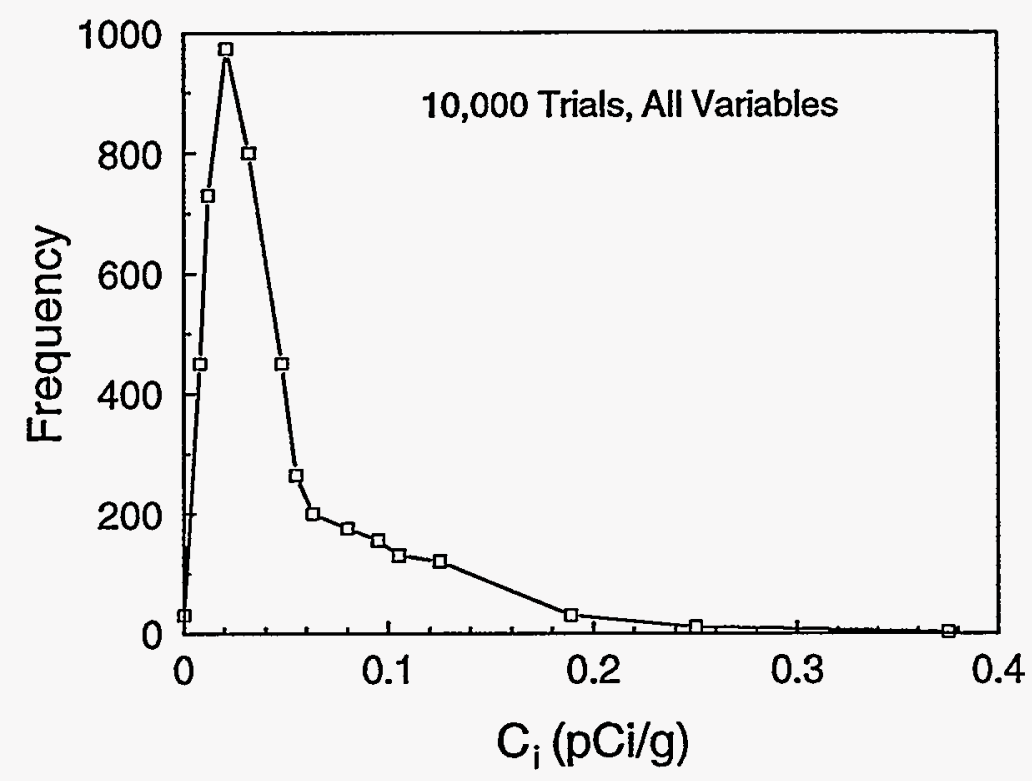

Figure 5. Distribution of DU concentrations in deer tissue, $C_{i}$, if uniform concentration of DU fragments is assumed for entire impact area. Simulation conditions were similar to those used for Figure 2. 
Table 2. Selected statistics from Monte Carlo simulation of DU in deer tissue, $\mathrm{C}_{\mathbf{i}}$. Entire impact area used as area of resuspension. See also Figure 5.

$\begin{array}{ll}\text { Number of Trials } & 10,000 \\ \text { Mean } & 59.6 \\ \text { Median } & 37.6 \\ \text { Mode } & 20.8 \\ \text { Standard Deviation } & 62.5 \\ \text { Range Minimum } & 0 \\ \text { Range Maximum } & 1170 \\ \text { Skewness } & 2.68\end{array}$

Soil ingestion is the parameter with the largest contribution of the three components described by Equation 1. The magnitude of the soil ingestion term depends mainly on the soil concentration of $\mathrm{DU}$, whereas the soil ingestion rate plays a secondary role. Figure 6 illustrates the dominance of $\mathrm{C}_{\mathrm{s}}$ in the soil ingestion term. DU ingested from drinking water is the secondmost important term in Equation 1 and depends on the water concentration of DU. The quantity of water consumed and the amount of water that is consumed from contaminated sources are of secondary importance as shown in Figure 7.

While the contribution from the plant term is small, there are several factors that should be discussed. Equation 2 shows the effect of DU internally deposited in plants through plant roots. The small magnitude of the bioconcentration factor indicates there is little DU taken into the plant through the roots. Higher soil concentrations, lower leaching rate $\left(\lambda_{1}\right)$, DU in finerdivided particles, and more extensive root systems in the contaminated soils would increase the amount of DU absorbed across plant roots. Relatively high concentrations of $U$ and other metals have been found in plants, but high plant concentrations occur mainly in areas of much greater $U$ availability in soils (Ibrahim and Whicker, 1988).

The contribution of DU deposited on plant surfaces, $C_{d}$, is more significant in this model than the DU absorbed through the root membranes. Equation 5 shows the factors that go into the calculation of surface deposited DU (Figure 8). The most sensitive factors are the size of the 

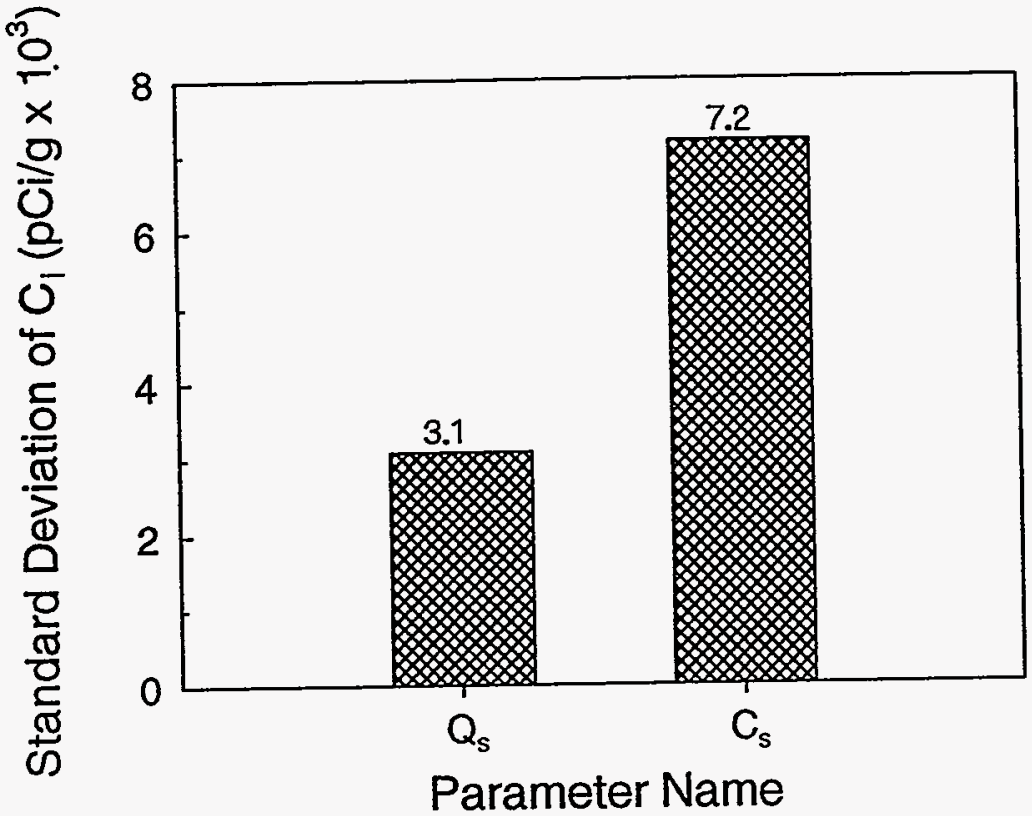

Figure 6. Standard deviation of $\mathrm{C}_{\mathrm{i}}$ due to variation in the soil ingestion pathway parameters only. The actual standard deviations are given above each bar. Values were obtained by allowing only one parameter, $Q_{S}$ or $C_{S}$, to vary during 10,000 simulations, then repeating the simulations letting the other parameter vary.

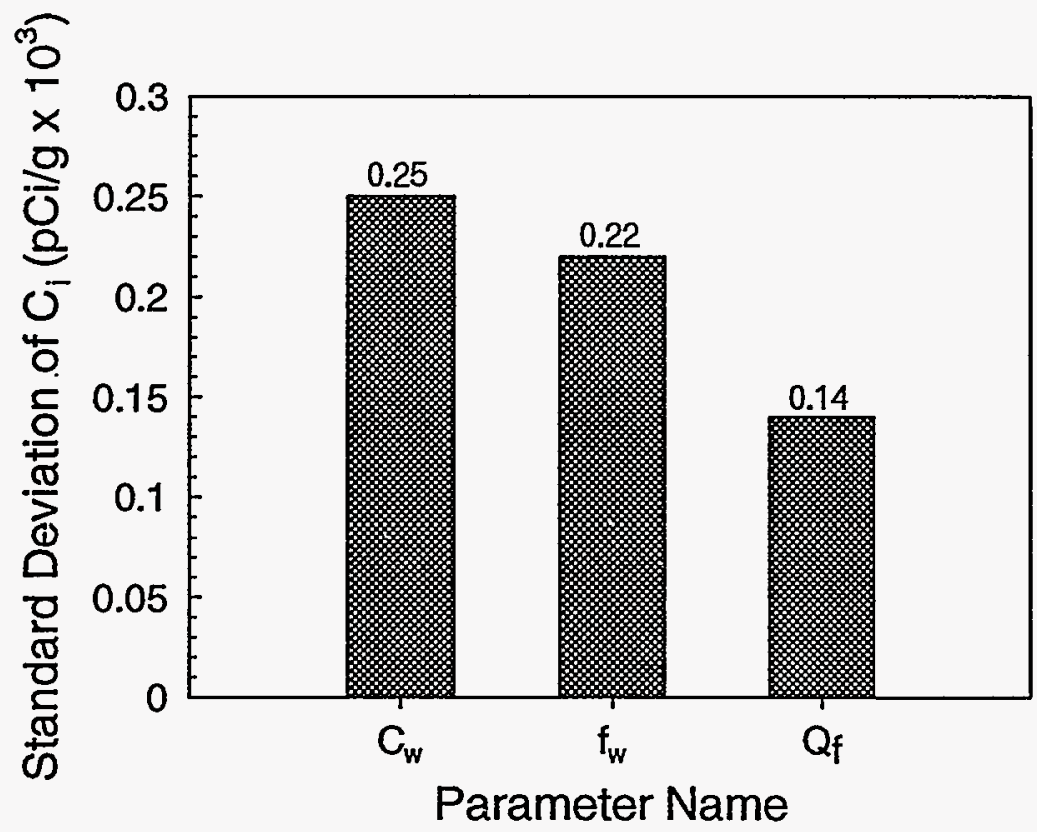

Figure 7. Standard deviations of $\mathrm{C}_{\mathrm{i}}$ due to variation in water consumption pathway parameters. The actual standard deviations are given above each bar. Values were obtained by allowing only one parameter to vary and holding the others constant during 10,000 simulations, then repeating the simulations letting the other parameters vary one at a time. 


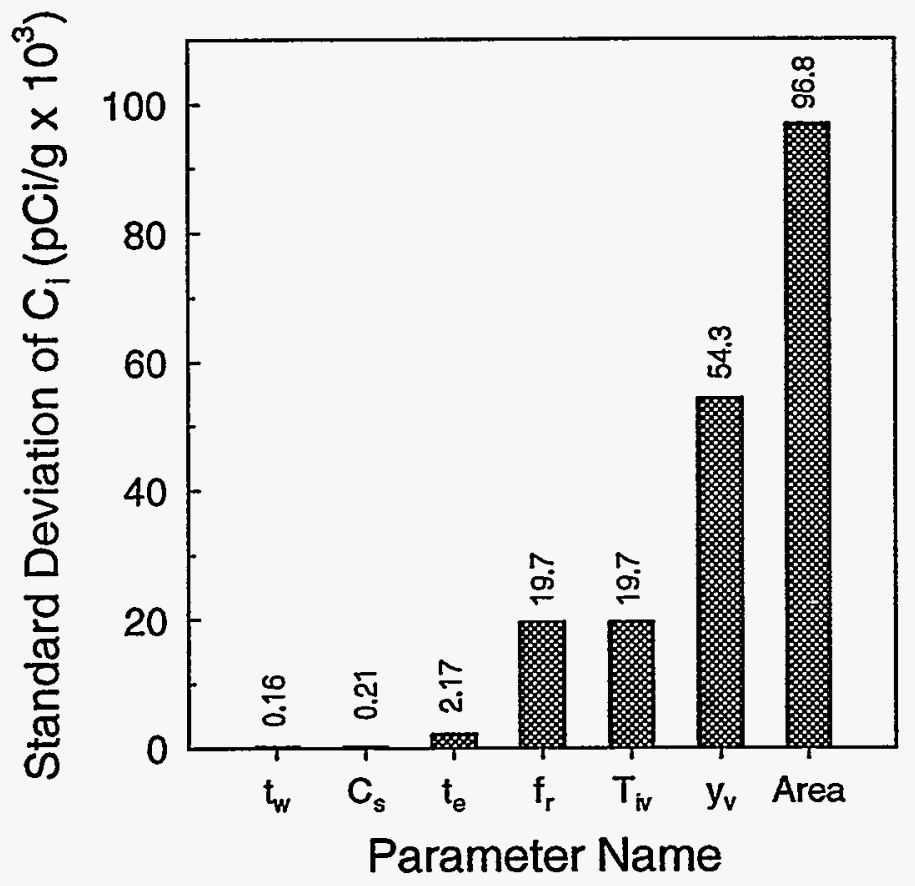

Figure 8. Standard deviations of $C_{i}$ due to variation in the $D U$ ingested from plant surfaces. The actual standard deviations are given above each bar. Values were obtained by allowing only one parameter to vary and holding the others constant during 10,000 simulations, then repeating the simulations letting the other parameters vary one at a time. 
area from which the available DU comes, discussed previously, and the biomass that is available as the depositional surface for DU and, therefore, as food for the deer. The interception fraction of the plants, $f_{r}$, and the translocation factor, $T_{v}$, are important but less so than the biomass and area of contamination parameters. The dependency of $\mathrm{C}_{\mathrm{d}}$ on the resuspension area, biomass, translocation factor, and interception fraction shows the importance of the density of the plants used for food and the amount of area covered by the plants. These factors interact sufficiently to alter the model output if a larger area for resuspension is used in the modeling or if large biomass is associated with any area.

\section{RESRAD Model}

The RESRAD model was developed for the DOE and is an acronym for Residual Radioactive Material Guidelines (Yu, et al, 1993). RESRAD is based on the same principles as the steady-state model but is far more complex in its handling of environmental pathways. The steady-state model described transport of DU (or other contaminants) from the source (deposition on the soil) through plants, soil, and water to deer and eventually to humans; RESRAD also models similar contaminant flow, but at a different level of detail. RESRAD describes the flow of DU from soil through many of the same pathways and also includes dose to humans from radon, resuspended DU inhaled directly from airborne dust and DU incorporated with plants, DU added to plants via irrigation, and dose due to irradiation from contaminated soil. Dose assessments to humans, and therefore risks of detriments to humans, are the focus of the RESRAD calculations and only limited information on the dose or exposure to the environment can be obtained.

RESRAD requires more data than the steady-state model because of the large number of compartments and interactions that are included. The ERM data were used extensively as input for the RESRAD simulations, but there are several additional parameters that are not explicitly described in the environmental report. For example, the soil porosity and volumetric water content are not discussed specifically in the environmental report, but there is sufficient 
information about soil types that reasonable estimates of these parameters could be made. Critical parameters such as concentrations of DU in soil and water were readily obtained from the environmental report. Appendix B is a tabulation of all the values used for the various RESRAD simulations that will be presented below.

RESRAD can be modified in order to simulate different land-use scenarios ranging from occasional site use, such as hunting several times of year to subsistence farming on the site by a resident family. Three scenarios were simulated in this report: 1) occasional use from hunting deer or other terrestrial animals four times per year for one week each time; 2) a family farming the site and obtaining all food (meat, milk, and vegetables) from the farm, but bringing drinking water for human consumption from an uncontaminated source; 3) the same scenario as 2) but all the drinking water is derived from wells on-site. These three scenarios bracket potential future use of the JPG DU impact area.

The input data for each scenario are presented in Appendix B and will be briefly discussed in this text. The environmental report provided enough data to estimate the average and maximum soil and water concentrations at JPG. The mean, standard deviation, and range in the environmental data are given in Table 3 for ${ }^{234} \mathrm{U}$ and ${ }^{238} \mathrm{U}$. Most of the other inputs were estimated from other information presented in the environmental report. Estimated values included the DU concentration in suspended dust; the amount of DU deposited on the surfaces of foliage used for food by animals and man; soil parameters including volumetric water content, erosivity indexes, and mineralogy; and the size of the area that was contaminated. The latter was an important parameter to estimate. Initially the contaminated area was set as that part of the impact area that contained most of the DU fragments, i.e., the majority of the impact area at JPG. The initial dimensions were $500 \mathrm{~m}$ (E-W) by $6000 \mathrm{~m}$ (N-S, along the firing line) or about $3 \times 10^{6}$ $\mathrm{m}^{2}$ and were based on the JPG controlled area. DU recovery data from APG showed that most of the fragments were recovered in two $500 \mathrm{~m}$-wide sections of the impact area extending from $1200 \mathrm{~m}$ to $2100 \mathrm{~m}$ beyond the B-3 catch box and from 2300 to $3100 \mathrm{~m}$ beyond the catch box, an area of about $8.5 \times 10^{5} \mathrm{~m}^{2}$. It is assumed that the amount recovered is proportional to 
Table 3. Range, mean, and standard deviations for soil and water concentrations from Abbott et al (1983). Concentrations are ${ }^{238} \mathrm{U}$ and ${ }^{234} \mathrm{U}$ activities as $\mathrm{pCi} / \mathrm{g}$ or $\mathrm{pCi} / \mathrm{L}$.

Soils

${ }^{234} \mathrm{U} \quad 238 \mathrm{U} \quad \Sigma \mathrm{U}^{1}$

Mean

$\begin{array}{lll}1.61 & 6.99 & 8.60\end{array}$

Standard Deviation

$3.84 \quad 24.13 \quad 27.50$

Minumum

0

Maximum

32.2

0

203.4

0

235.6

Water

Mean

$1.65 \quad 1.92$

2.99

Standard Deviation

2.47

Minumum

0.1

Maximum

19.6

4.53

6.70

0

34.5

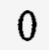

45.1

1. $\Sigma \mathrm{U}$ is the mean, standard deviation, and range calculated from $\sum_{i}^{n} U_{i}^{238}+U_{i}^{234}$.

the amount that remains on the impact area. Based on these two estimates of the contaminated area, $1 \times 10^{6} \mathrm{~m}^{2}$ was selected as the contaminated area at JPG.

Hunting or Occasional Use Scenario. The first scenario tested the use of the impact area for hunting or occasional recreational use. It is assumed that the site users will be in the impact area for no longer than one week per visit and visit the site four times a year. It is further assumed that all food and drinking water consumed by the users is brought in from off site and is uncontaminated above background levels. Hunters will take animals, in this case white tailed deer, raccoon, rabbit, or squirrel, and consume the edible portions in place of all or part of their normal variety of meat. The deer in the impact area were assumed to range within the impact area throughout their lives and consume all food and water from sources within the DU impact area. Thus, all food and water consumed by deer can be considered contaminated with DU. The animals hunted can be any other animals that occupy the site; but the data base on white tailed deer from JPG ERM data and the APG study were more extensive than for other animals. 
In addition, the hunter or occasional visitor fishes in the streams on the site and consumes the catch at home. The total amount of fish taken and consumed is considered to replace $50 \%$ of the fish consumed yearly in the visitor's or hunter's household. The hunter or occasional visitor spends the nights in tents pitched on the ground, and transportation while on the impact area is strictly on foot. The hunter's or visitor's range during the visit is the impact area itself with little movement outside the area except when entering or leaving.

The RESRAD simulations were run for 1000 years from the time the site is hypothetically available for use. Total dose, or dose to humans from all sources, is shown in Figure 9. The dose throughout the simulation is small (maximum of $0.15 \mathrm{mrem} / \mathrm{y}$ ) and is mainly due to dust inhalation and exposure to contaminated surface soil. Larger doses were estimated when the dust loading, or the dust concentration in the air, was increased by a factor of 10 . Dust loading greater than $200 \mu \mathrm{g} / \mathrm{m}^{3}$ could be imagined in heavily plowed areas or in extremely dusty environments, but it is not likely that such high dust loadings could be maintained for long periods. The JPG ERM data (Abbott et al, 1983) suggest an increase in airborne U during burning, but the increase is less than an order of magnitude over background. Therefore, the dose estimates from environments with high dust loadings are included mainly as illustration of the sensitivity of the model.

Since contaminated water is not consumed by the hunter or visitor, there is little contribution to the total dose from water-dependent pathways. Figure 10 shows the total dose from water-independent and water-dependent pathways. Figure 11 shows the total dose for the same scenario except that the soil concentration of DU was held at $35 \mathrm{pCi} / \mathrm{g}$. The total dose increased significantly when the $35 \mathrm{pCi} / \mathrm{g}$ soil concentration was used, but is still only a fraction of the allowable annual dose to the general public of $100 \mathrm{mrem} / \mathrm{y}$. The dust loading was varied as it was in Figure 9 to show the effects of extremely dusty conditions and on the sensitivity of the total dose to humans to this parameter.

Like the steady-state model above, RESRAD simulations can be subjected to sensitivity analysis, although the analysis is more limited than in the steady-state model. The sensitivity 


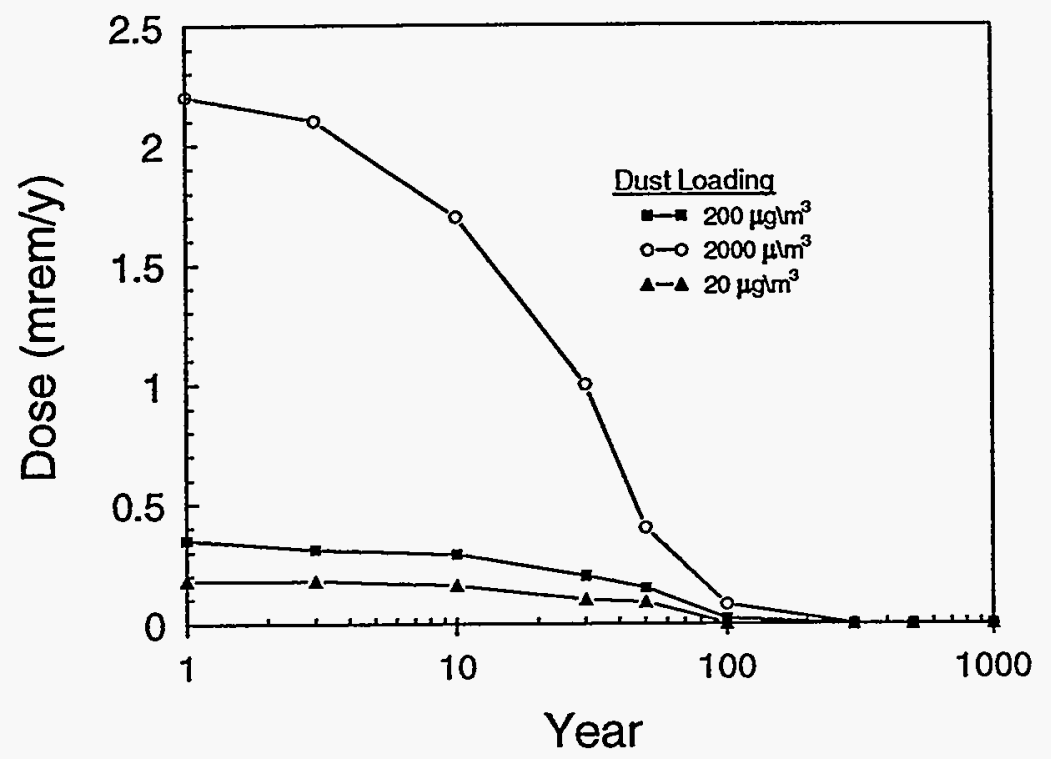

Figure 9. Dose calculated using RESRAD for all pathways in the hunting and occasional use scenario. Dust loading is the concentration of dust in the air and, therefore, related to the airborne DU concentration. Dust loading is one of the most sensitive parameters in the RESRAD simulations. Nominal dust loading is $200 \mu \mathrm{g} / \mathrm{m}^{3}$ in each RESRAD simulation.

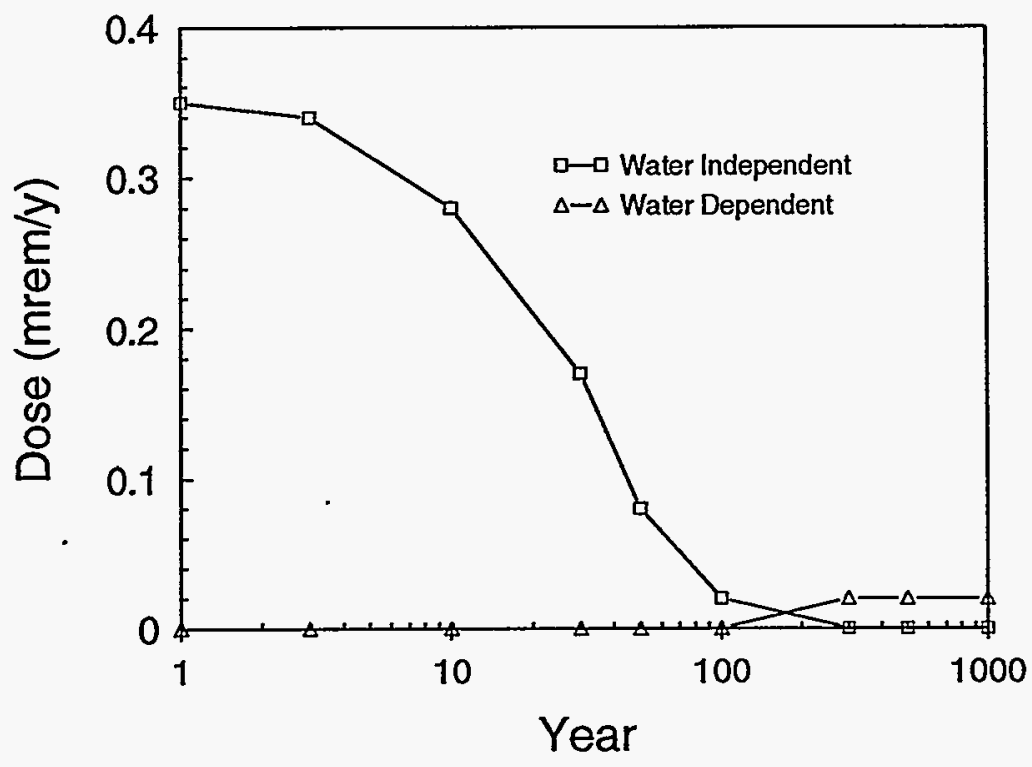

Figure 10. Water-dependent and water-independent contributions to the total dose from the hunting/occasional use scenario. Figure is based on nominal $\left(200 \mu \mathrm{g} / \mathrm{m}^{3}\right) \mathrm{dust}$ loading and average soil concentration. Water-dependent dose is low because drinking water was brought in and no on-site produce was consumed. 


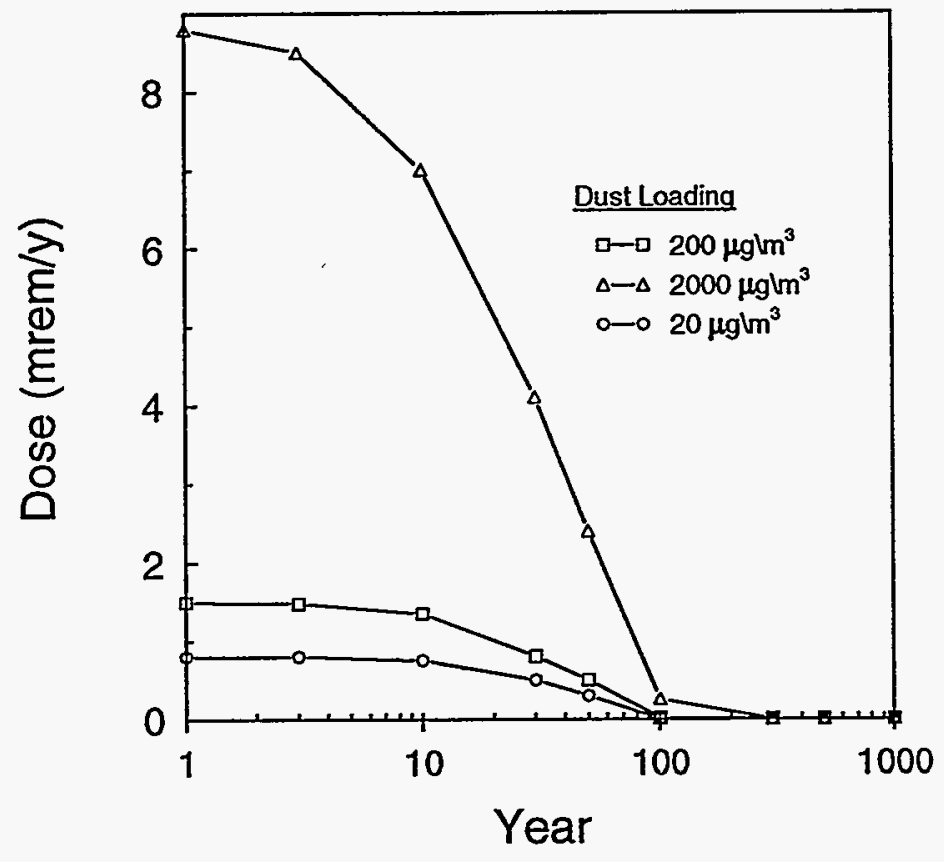

Figure 11. Total dose estimated using DU soil concentration of $35 \mathrm{pCi} / \mathrm{g}$, water concentration of $1 \mathrm{pCi} / \mathrm{l}$, and varying the dust loading. Graph illustrates the importance of actual soil and water DU concentrations in dose calculations. 
analysis provision showed that the parameter of most importance in the hunting scenario is the mass loading, i.e., dust concentration, of DU in the air. The value used in the simulations was the default value is $2 \times 10^{-4} \mathrm{~g} / \mathrm{m}^{3}\left(200 \mu \mathrm{g} / \mathrm{m}^{3}\right)$. Different values are cited, the largest coming from agricultural fields that are plowed during mass loading measurements (Sehmel, 1980). The default value of $2 \times 10^{-4} \mathrm{~g} / \mathrm{m}^{3}$ includes mechanical disturbance that could resuspend large quantities of contaminated soil in short periods of time and for short duration (Gilbert, et al, 1989). In addition, the default value is similar to the dust concentration reported in Cincinatti, Ohio, approximately 100 miles east of JPG. When the value was varied by one order of magnitude, the total dose increased significantly. However, $200 \mathrm{mg} / \mathrm{m}^{3}$ is a dust concentration that is extremely high and found only in situations of severe mechanical disturbance to soils such as immediately behind a disc plower. The effects of changes in the mass loading coefficient are shown in Figure 9 using average soil concentrations and Figure 11 using maximum soil and water concentrations. Variation in other input parameters resulted in small changes in the total dose, and no changes of the same magnitude as for the mass loading coefficient were observed. There is little risk of death due to radiation-induced cancer or human detriment resulting from this scenario.

Resident Farming Scenario \#1. The first resident farming scenario tested includes a family or families living on the impact area full time and producing all meat and vegetables from fields in the contaminated area. Livestock fodder is produced on-site and all irrigation for plants and drinking water for animals is pumped from the aquifer that contains small amounts of DU. The family, however, obtains their drinking water from an uncontaminated source off-site such as the City of Madison, Indiana. Figure 12 shows the results of the resident farming scenario with supplied drinking water.

The total dose for this scenario is again dominated by the dose from inhaled dust and partly by irradiation from contaminated soil early in the simulation. After about year 30 the contribution from the meat and produce grown on the farm contributes significantly. The total 


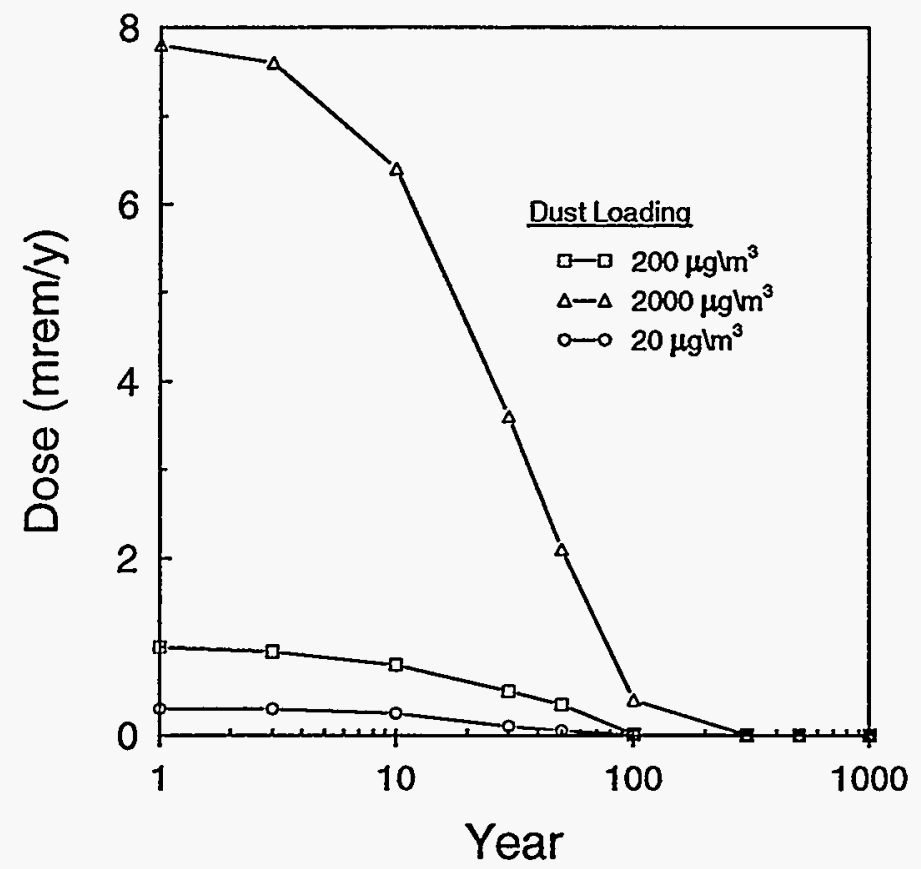

Figure 12. Total dose from farming scenario \#1 using average soil concentration. Dust loading is the most sensitive parameter, and the range is the same as in previous figures. Dose to humans is significantly greater than hunting scenario due to longer times on the site and consumption of more produce from the site. 
dose, however, is low, about $1.3 \mathrm{mrem} / \mathrm{y}$, well below the $100 \mathrm{mrem} / \mathrm{y}$ exposure limit for the general public.

Figure 13 shows the doses due to water-dependent and water-independent pathways. Sensitivity analyses of this scenario indicate that the mass loading is again an important variable, especially early in the simulation (Figure 12). The analyses also showed that the amount of irrigation water applied influenced the total dose, but there was little increased dose from increased water consumption by livestock. Variation in the distribution coefficients in the contaminated zone soils and in the aquifer also had little effect. The water-independent pathways contributed about the same proportion of the total dose as in the hunting scenario, but the waterdependent pathways showed a much different pattern (Figures 13 and 14). Inhalation of DU and surface exposure were the largest contriubtors to humans dose; consumption of plants, milke, and meat were significant but small contributors.

The total dose increased significantly when soil and water DU concentrations were 35 $\mathrm{pCi} / \mathrm{g}$ (Figure 15). The nominal case $\left(2 \times 10^{-4} \mathrm{~g} / \mathrm{m}^{3}\right)$ showed about $8 \mathrm{mrem} / \mathrm{y}$ total dose, and about $34 \mathrm{mrem} / \mathrm{y}$ when the mass loading increased by an order of magnitude (Figure 15). Mass loadings of $2 \times 10^{-3} \mathrm{~g} / \mathrm{m}^{3}$ are much greater than the average loading to which the residents would be exposed, but this value illustrates that the $100 \mathrm{mrem} / \mathrm{y}$ limit can be approached under unreasonably concentrations of dust. The water-independent and water-dependent pathways contributed about the same proportions to the total dose for the average soil and water DU concentration as they did in the hunting scenario above (Figure 16).

Resident Farming Scenario \#2. The second farming scenario is the same as Farming Scenario \#1 but also includes use of well water from the site as the drinking water supply for the resident family. As expected, the total dose to humans under this scenario is significantly higher than in the previous farming scenario (Figure 17). Doses from all pathways exceed $100 \mathrm{mrem} / \mathrm{y}$ between year 10 and year 100 when average $\mathrm{DU}$ soil concentration and $1 \mathrm{pCi} / 1$ are used for part of the simulation period. Figure 18 shows that drinking water consumption dominates both the dose from water dependent pathways and the total dose. The largest dose from water 


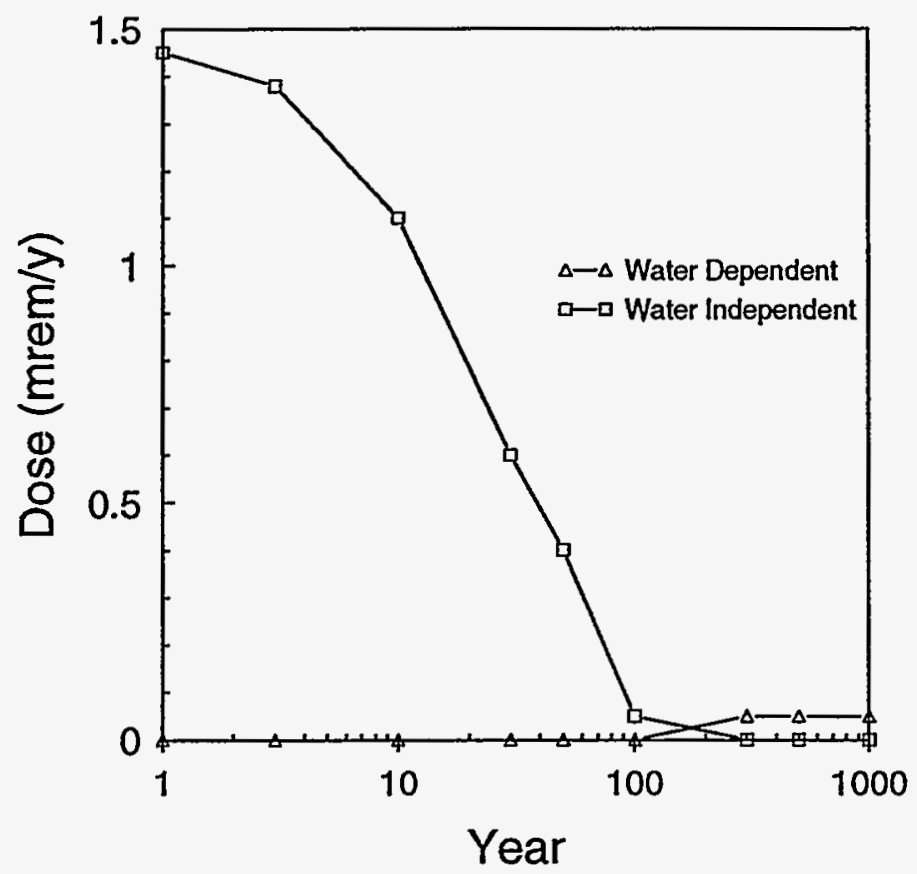

Figure 13. Water-dependent and water-independent contributions to total dose, farming scenario $\# 1$ and average soil concentration. Dose from water dependent sources is due to consumption of produce, meat, and fish. Dose from water independent pathway is from dust inhalation and irradiation from contaminated soil. Figure based on nominal $\left(200 \mu \mathrm{g} / \mathrm{m}^{3}\right)$ dust loading.

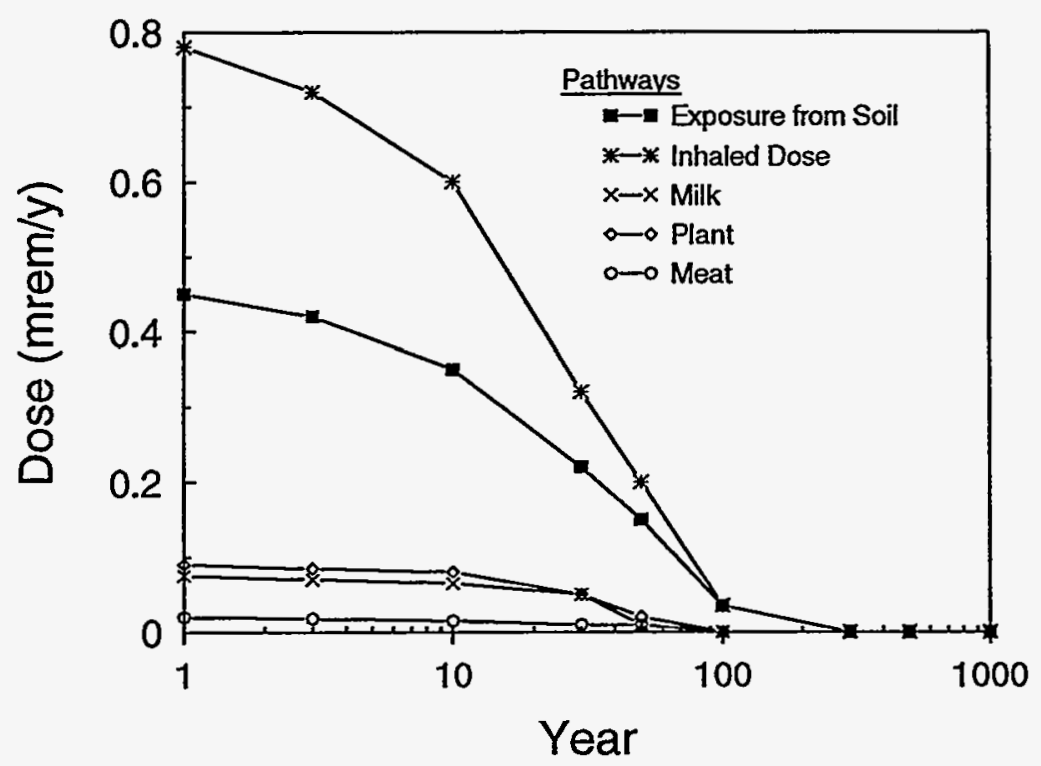

Figure 14. Dose from water-dependent pathways, farming scenario \#1, average soil concentration. Nominal $\left(200 \mu \mathrm{g} / \mathrm{m}^{3}\right)$ dust loading used for this figure. 


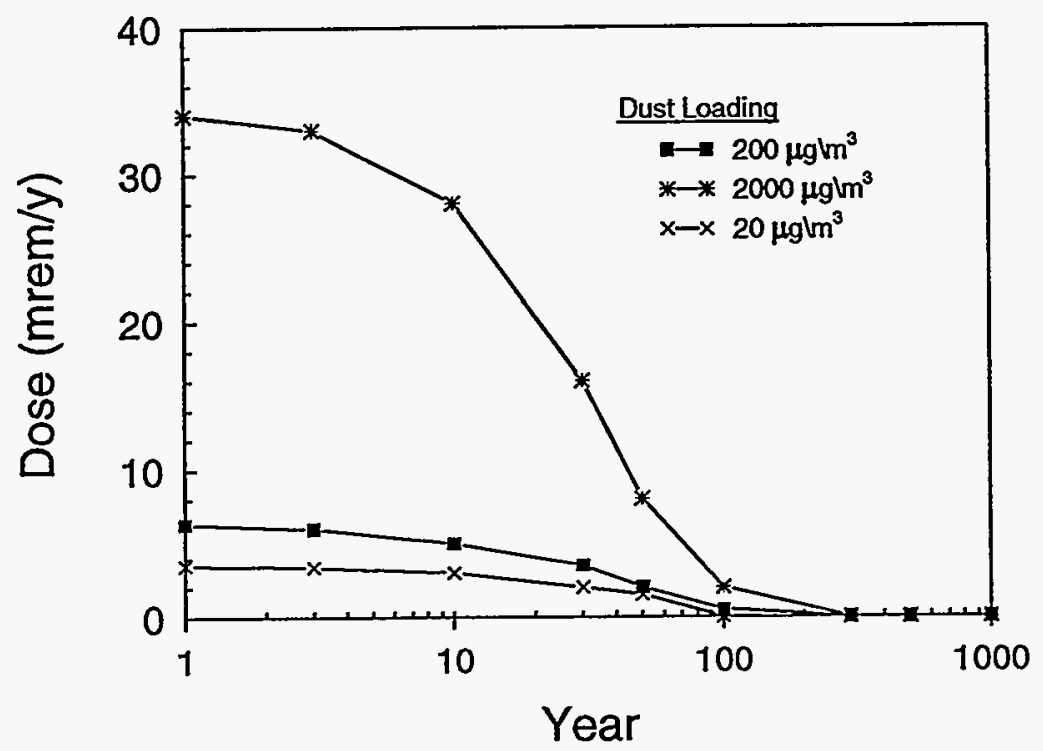

Figure 15. Total dose, farming scenario \#1, assuming $35 \mathrm{pCi} / \mathrm{g}$ soil and water concentrations of $1 \mathrm{pCi} / 1 \mathrm{DU}$ across the site.

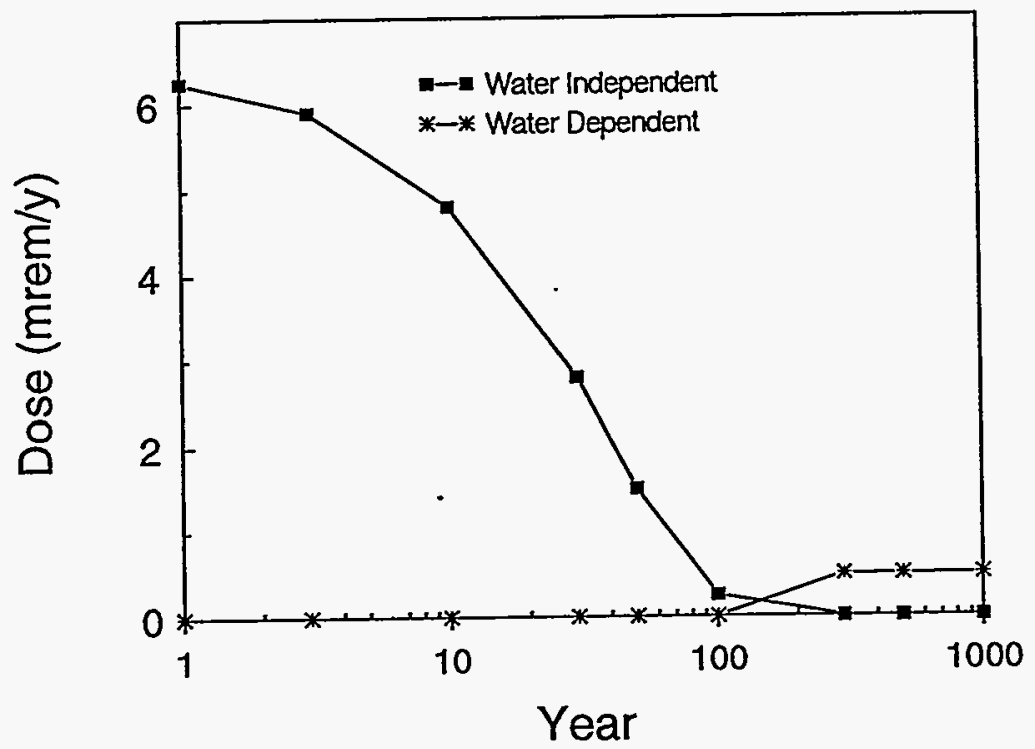

Figure 16. Water dependent and water independent contributions to total dose farming scenario \#1. Soil concentration of $35 \mathrm{pCi} / \mathrm{g}$ and water concentration of $1 \mathrm{pCi} / 1$ were assumed throughout the site as in Figure 15. Nominal dust loading used for this graph. 


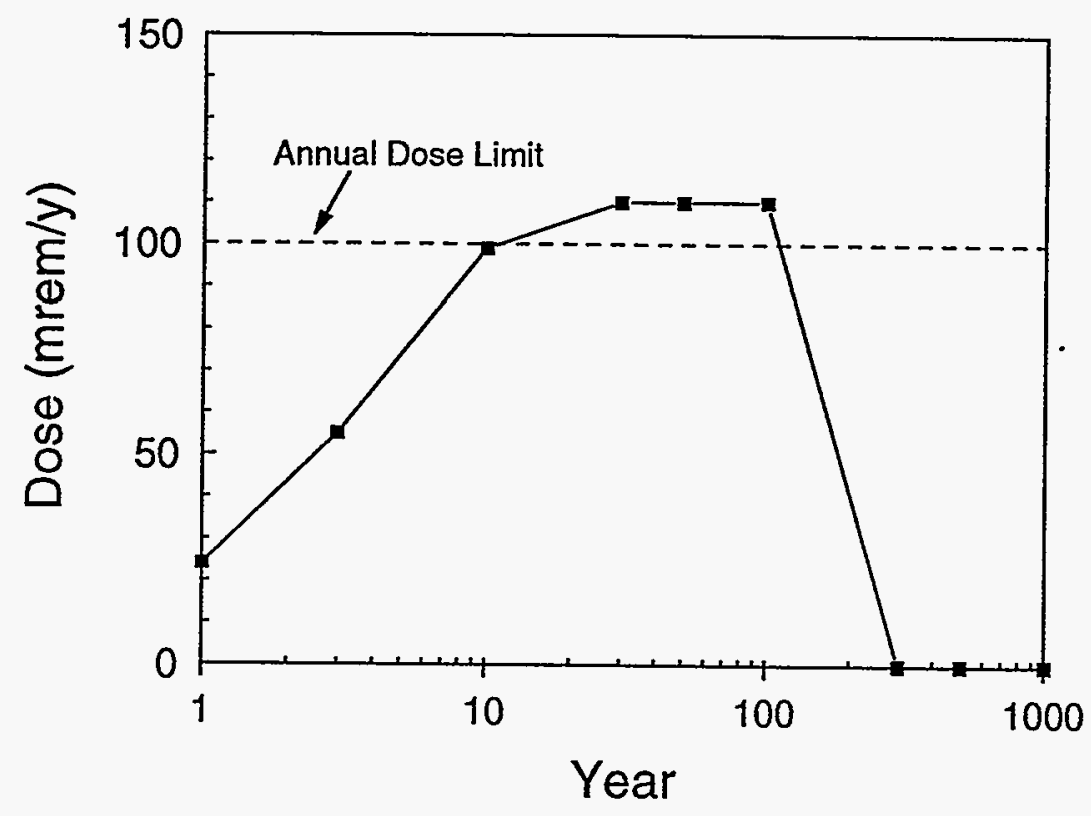

Figure 17. Total dose, farming scenario \#2, average soil concentration and $1 \mathrm{pCi} / 1$ in water. Dust loading range same as in previous figures.

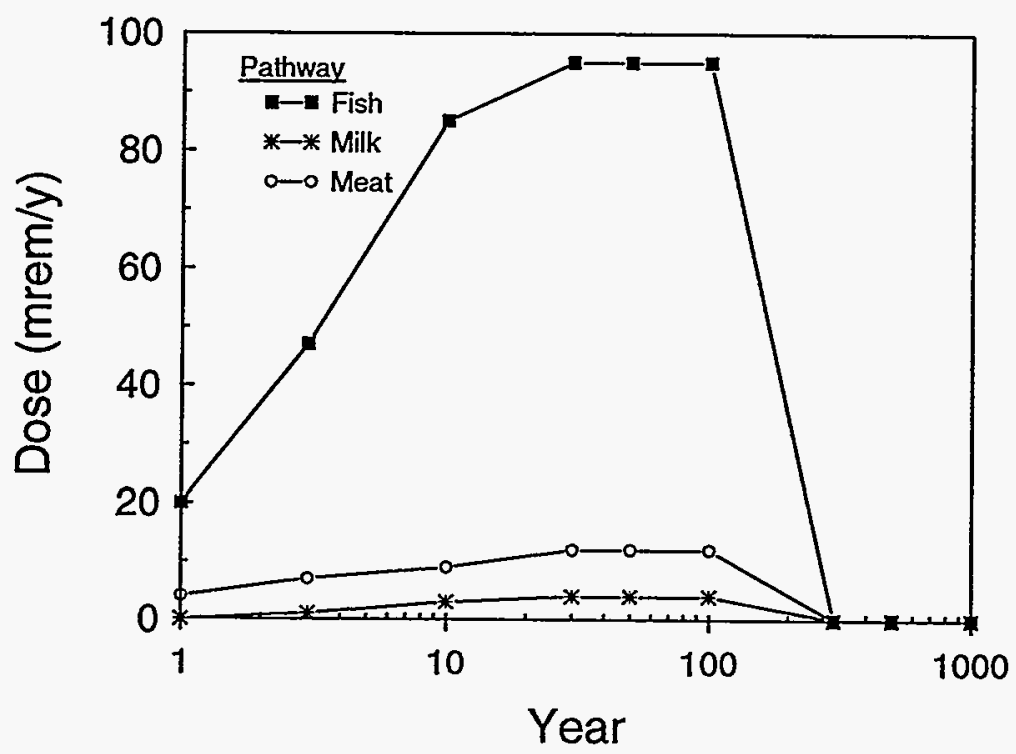

Figure 18. Water dependent contributions to total dose, farming scenario \#2, average soil concentration and $1 \mathrm{pCi} / \mathrm{l}$ in water. Nominal $\left(200 \mu \mathrm{g} / \mathrm{m}^{3}\right)$ dust loading used for this figure. Total dose dominated by the contributions from fish concumption and drinking water. Compare to Figure 14. 
independent pathways was from inhaled DU, but the total contribution was less than $1 \%$ of the total dose (Figure 19).

Increasing the soil concentration to $35 \mathrm{pCi} / \mathrm{g}$ and keeping the water concentration at 1 $\mathrm{pCi} / \mathrm{l}$ resulted in total dose to the site resident well in excess of $100 \mathrm{mrem} / \mathrm{y}$ (Figure 20). The dose from water dependent pathways and the total dose were dominated again by the consumption of drinking water with minor contribution from inhalation of DU. Figure 21 shows the importance of drinking water consumption on the total dose, and Figure 22 shows the relative contriubutions of water-dependent and water-independent pathways. The total dose exceeds 100 $\mathrm{mrem} / \mathrm{y}$ from year 1 through year 100 because of the increased transport of DU through the system.

Doses to Humans Estimated from Models

The models discussed in the previous sections provide estimates of $\mathrm{DU}$ concentration in different ecological compartments, or in the case of RESRAD, provide dose estimates from different pathways. Since the models define the pathways and methods used to calculate DU concentrations, different values of the doses were obtained from different models. The steadystate model generates doses that remain constant through time since time-dependent values are not used in the model. Doses calculated from the steady-state model are therefore conservative because they do not show the effects of DU source-term depletion with time. Doses calculated from RESRAD, on the other hand, show important temporal effects that the steady-state model cannot show. For example, Figures 17 and 20 show increasing dose through the first 10 to 20 years, a maximum in the dose for the next 200 years, then a sharp decrease due to DU sourceterm depletion or flushing the DU out of the system.

The doses for the steady-state model were calculated by converting the expected $\mathrm{C}_{\mathrm{i}}$ values to dose rates using Equation 7: 


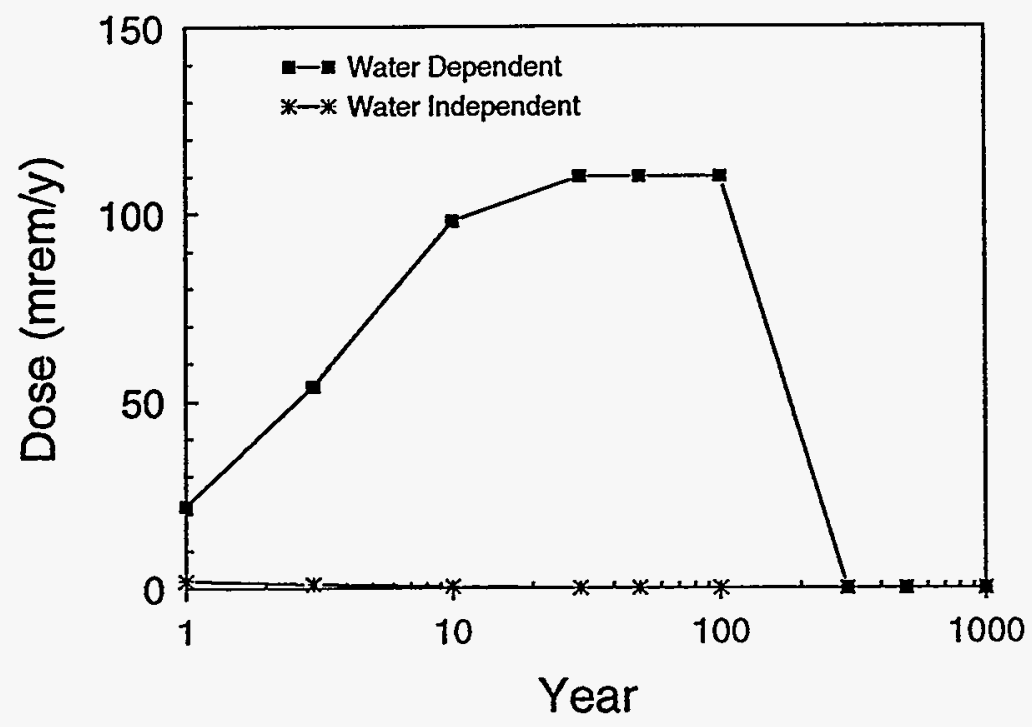

Figure 19. Water dependent and water independent contributions to total dose, farming scenario $\# 2$, average soil concentration and $1 \mathrm{pCi} / \mathrm{l}$ in water. Nominal $\left(200 \mu \mathrm{g} / \mathrm{m}^{3}\right)$ dust loading used.

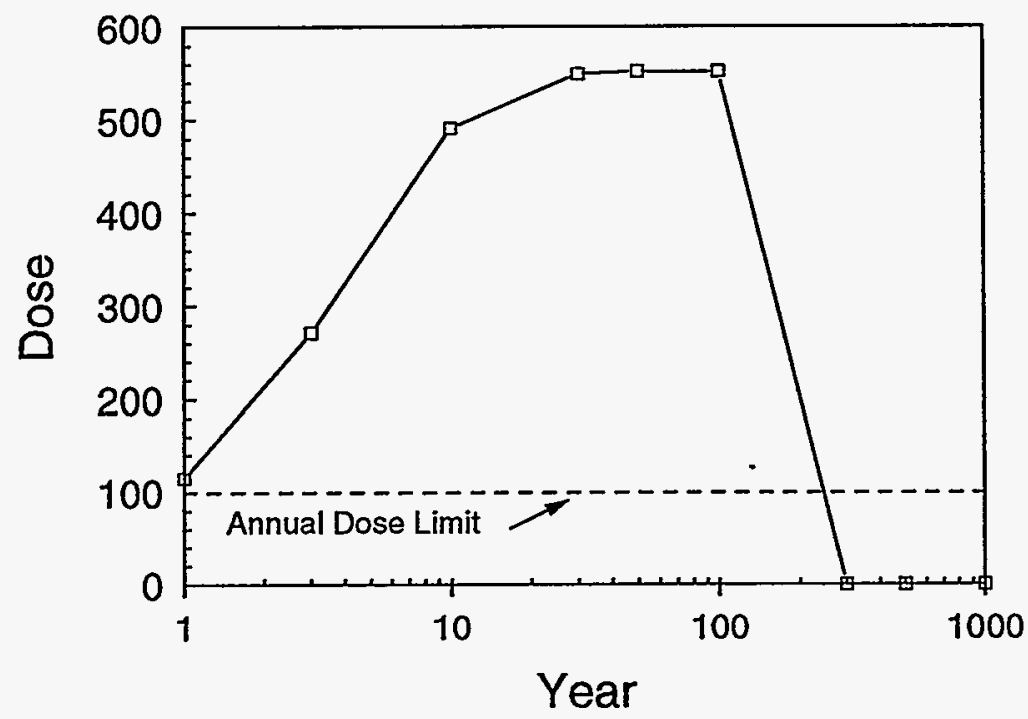

Figure 20. Total dose assuming soil concentration of $35 \mathrm{pCi} / \mathrm{g}$ and water concentration of $1 \mathrm{pCi} / 1$ across the site, farming scenario \#2. Nominal dust loading used for this graph. 


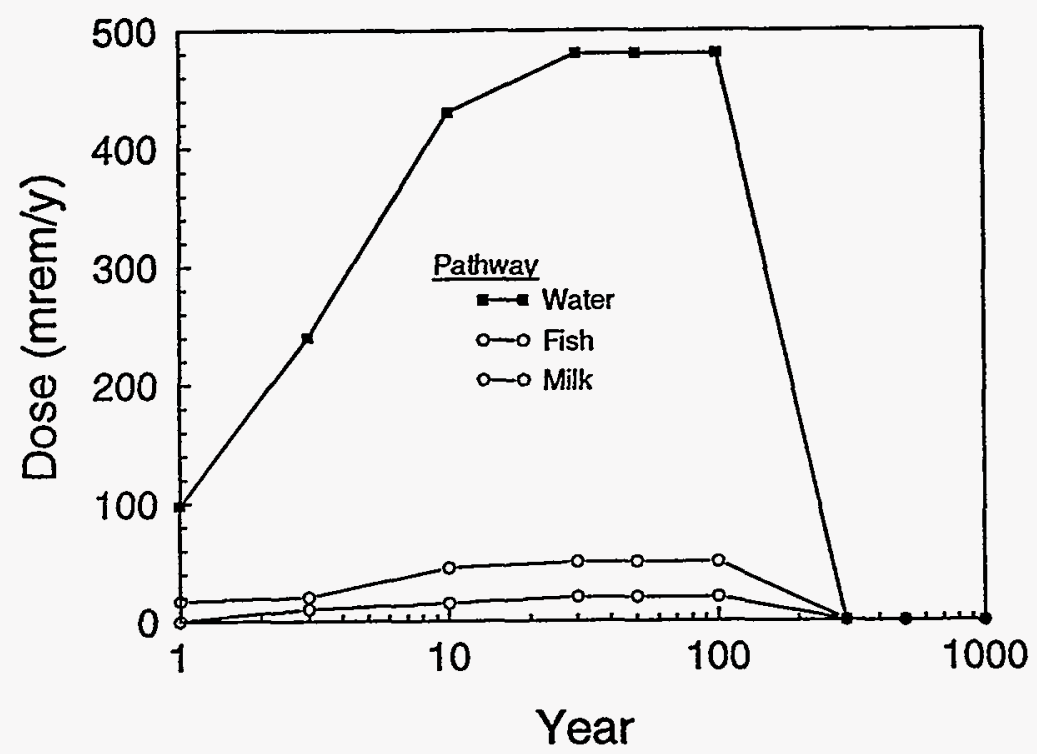

Figure 21. Contributions from water-dependent pathways to total dose based on soil concentration of $35 \mathrm{pCi} / \mathrm{g}$ and water concentration of $1 \mathrm{pCi} / \mathrm{l}$. Dose is dominated by fish and water consumption with relatively small contributions from different pathways.

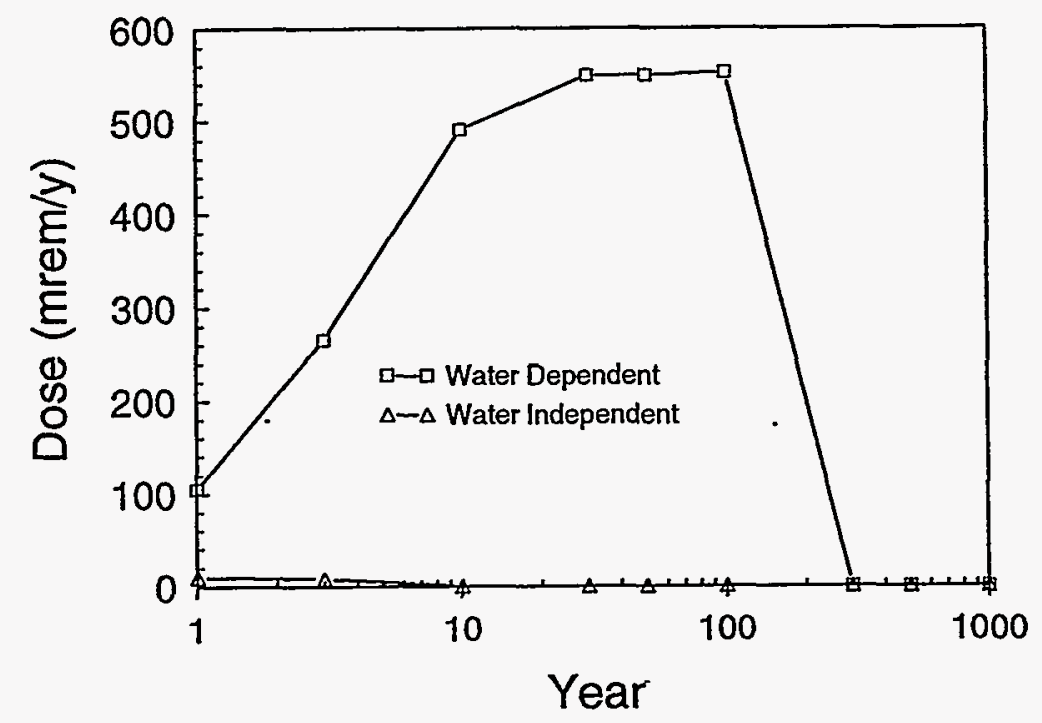

Figure 22. Water-dependent and water-independent contributions to total dose assuming soil concentration of $35 \mathrm{pCi} / \mathrm{g}$ and water concentration of $1 \mathrm{pCi} /$, farming scenario \#2. The large contribution from the water dependent pathway is due to consumption of fish and drinking water at the site and DU transfer to produce, meat, and milk. 


$$
E=\frac{\left(C_{i} Q_{m} f_{a}\right) * D C F * w_{t}}{1000}
$$

where $E$ is the effective annual dose (mrem/y), $C_{i}$ is defined in Equation $1, Q_{m}$ is the quantity of meat consumed yearly, $f_{a}$ is the fraction of DU absorbed into the body (i.e., the $D U$ that is not initially excreted), DCF is the dose conversion factor (DOE, 1988), $\mathrm{w}_{t}$ is the appropriate tissue weighting factor (ICRP, 1990), and 1000 is a units conversion factor. Table 4 shows the values for $D C F$ and $w_{t}$ used for the conversions. The effective dose was calculated for exposure of different tissue to DU, and the CEDE was used so that doses from the Steady-Sate model could be compared with doses calculated from the RESRAD model. Since the CEDE is a measure of the effective dose equivalent to all organs, the $w_{t}$ is 1 . The radiological doses were calculated with the values of $C_{i}$ in the steady-state model, thus the estimated doses were subjected to the same sensitivity and uncertainty analyses as $\mathrm{C}_{\mathbf{i}}$. The mean, median, mode, and standard deviations of the effective doses are given in Table 5.

Annual effective dose calculations using the steady-state model are low for exposure of kidney $\left(1.85 \times 10^{-3} \mathrm{mrem} / \mathrm{y}\right)$, bone surface $\left(0.92 \times 10^{-3} \mathrm{mrem} / \mathrm{y}\right)$, and GI tract $\left(7.0 \times 10^{-2}\right.$ $\mathrm{mrem} / \mathrm{y}$ ), as well as for the cumulative effective dose equivalent (CEDE, $0.62 \mathrm{mrem} / \mathrm{y}$ ). The low doses reflect the small amounts of DU transferred through different pathways considered in the model. Table 5 lists the mean, median, mode, and standard deviations of the doses estimated with the steady-state model.

Comparison of the CEDE values from the steady-state model in Table 5 with the dose rates calculated for the hunting scenario with RESRAD show similar trends but clearly different values. Tables 5 and 6 from the steady-state model and RESRAD model, respectively, show clear differences between the two types of models. Figures 9 and 10 show the dose rate over time from all components in the model, thus, the values shown in the figures do not agree with the values in Table 6. However, when only the dose from meat consumption in the RESRAD results are used for the comparison the two sets of calculations are in much better agreement. 
Table 4. Dose conversion factors for ${ }^{238} \mathrm{U}$ and ${ }^{235} \mathrm{U}\left(\mathrm{DCF}_{\mathrm{U}}, \mathrm{rem} / \mathrm{Ci}\right)$ and tissue weighting factors $\left(\mathrm{w}_{\mathrm{t}}\right)$ used for calculating human doses and detriment due to radiation.

$\begin{array}{ccccc} & \text { Kidney } & \text { Bone Surface } & \text { GI Tract } & \text { CEDE } \\ \text { DCF }^{1} & 1.5 & 3.7 & 0.05 & 0.23 \\ \mathrm{w}_{\mathrm{t}}{ }^{2} & 0.05 & 0.01 & 0.05 & 1.0\end{array}$

1 Source: DOE, 1988.

2 Source: ICRP, 1990.

Table 5. Estimated human dose from consumption of deer tissue, steady-state model. Doses for all but CEDE include appropriate tissue weighting factor (ICRP, 1990).

\begin{tabular}{lcccc} 
Human Tissue & \multicolumn{2}{c}{ Dose (in $10^{-3}$ mrem/y) } & & \\
& Mean & Median & Mode & Standard Deviation \\
Kidney & 1.85 & 1.04 & .03 & \\
Bone Surface & 0.92 & 0.51 & 0.017 & 2.36 \\
GI Tract & 0.07 & 0.04 & 0.008 & 1.2 \\
CEDE $^{1}$ & 0.62 & 0.36 & 0.083 & 0.13 \\
& & & & 0.75
\end{tabular}

1 CEDE is the cumulative effective dose equivalent, or the summation of the effective doses to all tissues.

The largest RESRAD dose is about $0.36 \mathrm{mrem} / \mathrm{y}$ from consumption of deer meat, whereas the steady-state model is $0.62 \mathrm{mrem} / \mathrm{y}$. The RESRAD dose, moreover, falls within the standard deviation of the steady-state model result. The RESRAD calculations for the hunting scenario also show that the contribution to the total human dose from meat consumption is the largest contribution from food products (Figure 23), and that there is a significant contribution to dose from the dust inhaled by humans and from contaminated soil (Figure 24). The trend in the steady-state model as well as the meat consumption portion of the RESRAD model support the conclusion that little DU is transferred to humans by the deer consumption pathway. 


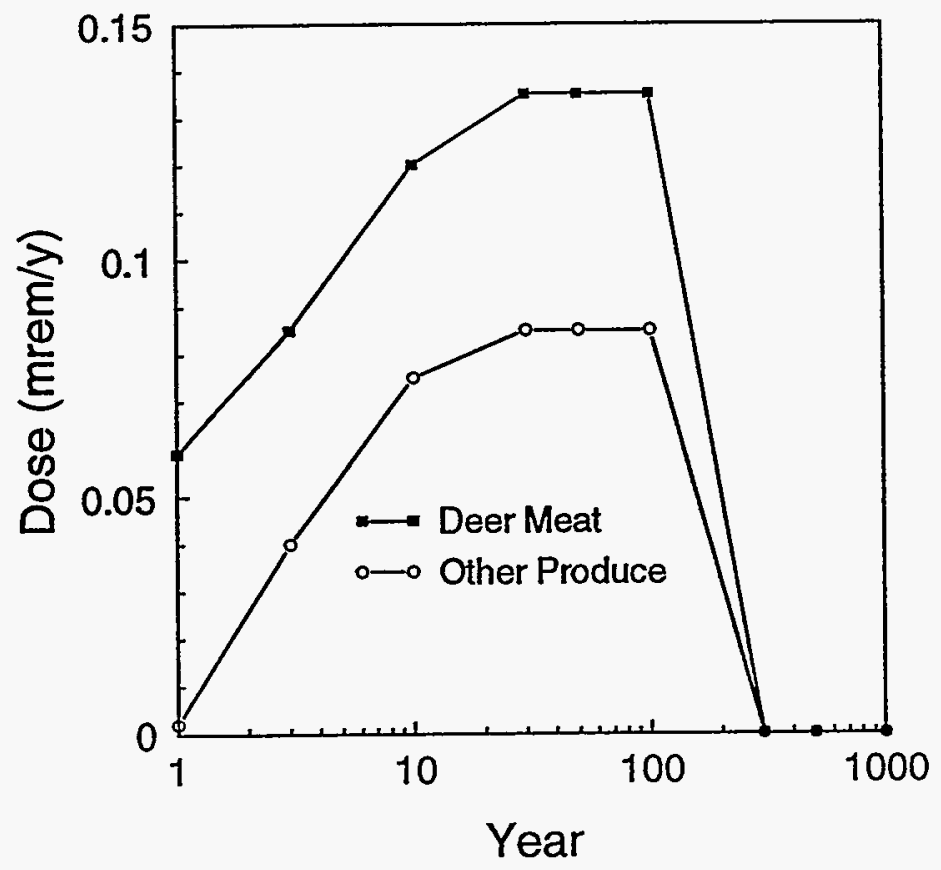

Figure 23. Contribution of deer meat and all other produce to human dose for the hunting scenario. Graph based on nominal $\left(200 \mu \mathrm{g} / \mathrm{m}^{3}\right)$ dust loading and average soil concentrations.

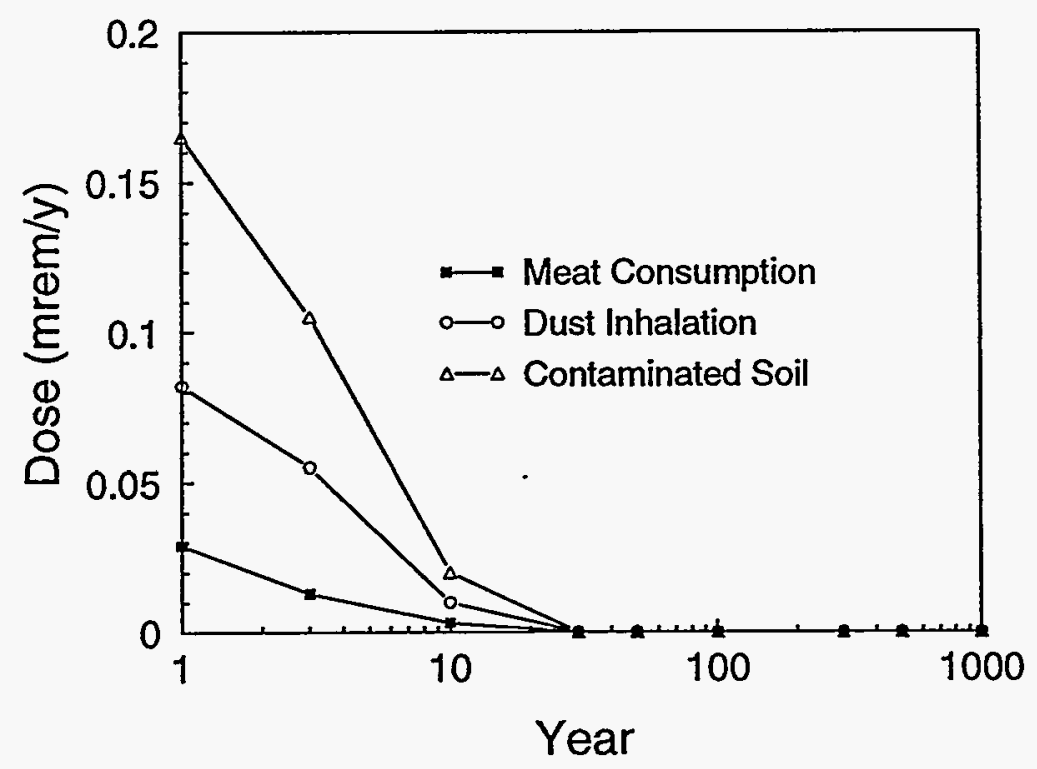

Figure 24. Contributions to human dose from exposure to contaminated soil, direct inhalation, and consumption of deer meat. Graph based on nominal $\left(200 \mu \mathrm{g} / \mathrm{m}^{3}\right)$ dust loading and average soil concentrations. 
Table 6. Annual doses (mrem/y) from all pathways calculated from RESRAD model scenarios. Annual dose is based on CEDE and is shown for each year of the simulations. Doses for average and $35 \mathrm{pCi} / \mathrm{g}$ soil and water concentrations given.

\begin{tabular}{|c|c|c|c|c|c|c|c|c|c|c|}
\hline \multicolumn{11}{|l|}{ Hunting Scenario } \\
\hline Year & 0 & 1 & 3 & 10 & 30 & 50 & 100 & 300 & 500 & 1000 \\
\hline Dose (mrem, Ave.) & 0.36 & 0.35 & 0.33 & 0.28 & 0.16 & 0.09 & 0.02 & $5.6 \times 10^{-3}$ & $6.0 \times 10^{-3}$ & $6.3 \times 10^{-3}$ \\
\hline Dose (mrem, $35 \mathrm{pCi} / \mathrm{g}$ ) & 1.6 & 1.5 & 1.4 & 1.2 & 0.7 & 0.4 & 0.07 & 0.02 & 0.02 & 0.02 \\
\hline \multicolumn{11}{|l|}{ Farming Scenario \#I } \\
\hline Year & 0 & 1 & 3 & 10 & 30 & 50 & 100 & 300 & 500 & 1000 \\
\hline Dose (mrem, Ave.) & 1.48 & 1.44 & 1.37 & 1.14 & 0.66 & 0.37 & 0.07 & 0.05 & 0.05 & 0.06 \\
\hline Dose (mrem, $35 \mathrm{pCi} / \mathrm{g})$. & 6.43 & 6.27 & 5.94 & 4.94 & 2.87 & 1.63 & 0.32 & 0.21 & 0.22 & 0.23 \\
\hline \multicolumn{11}{|l|}{ Farming Scenario \#2 } \\
\hline Year & 0 & 1 & 3 & 10 & 30 & 50 & 100 & 300 & 500 & 1000 \\
\hline Dose (mrem, Ave.) & 1.63 & 23.3 & 54.6 & 98.7 & 110.1 & 110.1 & 110.7 & 0.096 & 0.1 & 0.1 \\
\hline Dose (mrem, $35 \mathrm{pCi} / \mathrm{g})$. & 6.6 & 115 & 271 & 490 & 548 & 549 & 551 & 0.05 & 0.05 & 0.06 \\
\hline
\end{tabular}

Estimated Risk Calculated from Doses

The estimated detriments to humans from the above dose rates were calculated using the ICRP guidelines (ICRP, 1990). Detriments, for the purpose of converting the doses estimated using the above models, are the sum of radiation-induced fatal cancers, non-fatal cancers, and severe hereditary effects in humans.

Table 7 shows the estimated detriments to humans based on the results of the steady-state model. The total detriment to humans, including radiation workers or the general population, is between $3.5 \times 10^{-7}$ detriments per year and $4.5 \times 10^{-7}$ detriments per year based on the cumulative effective does equivalent (CEDE) of Table 4. Detriment due to doses to other tissues are of the same magnitude as calculated using the CEDE. Table 8 shows the estimated detriments to adult radiation workers and the whole population from the doses calculated in the RESRAD simulations. Farming scenario \#2 generates the highest human health risks, as expected, because of the highest ingestion of and exposure to contaminated soils, food, and water; the hunting scenario generates the lowest risk because of minimal ingestion and exposure. 
Doses used for Table 8 include average and maximum soil and water DU concentrations but show only default dust loading simulations $(200 \mu \mathrm{g} / \mathrm{L})$.

Simulations run with average soil and water concentrations show expected annual detriment of the same magnitude as the results from the steady-state model until about year 300, then significantly lower dose and detriments per year thereafter. Farming scenario simulations at maximum soil and water concentrations show annual detriments in the $10^{-5}$ range. These results suggest the importance of using accurate soil and water concentrations and the importance of using reasonable dust loadings (i.e., much less than $2000 \mu \mathrm{g} / \mathrm{m}^{3}$ ) in order to provide a better upper bound on the soil and water concentrations used in the simulations. RESRAD and the steady-state model assume that the values of soil and water concentrations are uniform across the area of contamination. The environmental data show that DU concentrations in soil and water vary considerably as do DU concentrations in most of the parameters monitored. The doses and detriments calculated for the highest soil and water concentrations are conservative in that they assume soil and water DU concentrations for the entire impact area that are higher than have been documented by the environmental data. 
Table 7. Conversion of annual doses to annual detriments in adult workers and the whole population from the steady-state model. Detriments are tabulated below as $10^{-7}$ detriments per year, and are a sum of fatal cancers, non-fatal cancers, and severe hereditary effects. Conversion based on $1 \times 10^{-2}$ detriments/Sv or $1 \times 10^{-7}$ detriments/mrem (ICRP, 1990).

\section{Adult Workers}

$\begin{array}{cccccc} & \text { Dose Rate } & \text { Fatal } & \text { Non-Fatal } & \text { Hereditary } & \\ \text { Tissue } & (\mathrm{mrem} / \mathrm{y}) & \text { Cancer } & \text { Cancer } & \text { Effects } & \text { Total } \\ \text { Kidney } & 1.85 \times 10^{-3} & 7.4 & 1.5 & 1.5 & 10.0 \\ \text { Bone Surface } & 0.92 \times 10^{-3} & 3.7 & 0.7 & 0.7 & 5.2 \\ \text { GI Tract } & 0.07 \times 10^{-3} & 0.3 & 0.06 & 0.06 & 0.4 \\ \text { CEDE } & 0.62 \times 10^{-3} & 2.5 & 0.5 & 0.5 & 3.5\end{array}$

Whole Population

$\begin{array}{cccccc}\text { Tissue } & \begin{array}{c}\text { Dose Rate } \\ (\mathrm{mrem} / \mathrm{y})\end{array} & \begin{array}{c}\text { Fatal } \\ \text { Cancer }\end{array} & \begin{array}{c}\text { Non-Fatal } \\ \text { Cancer }\end{array} & \begin{array}{c}\text { Hereditary } \\ \text { Effects }\end{array} & \text { Total } \\ \text { Kidney } & 1.85 \times 10^{-3} & 9.3 & 1.9 & 2.4 & 14.0 \\ \text { Bone Surface } & 0.92 \times 10^{-3} & 4.6 & 0.9 & 0.1 & 6.7 \\ \text { GI Tract } & 0.07 \times 10^{-3} & 0.4 & 7.0 & 0.1 & 0.5 \\ \text { CEDE } & 0.62 \times 10^{-3} & 3.1 & 0.6 & 0.8 & 4.5\end{array}$


Table 8. Excess cancer risks based on doses in Table 6. Excess cancers are tabulated as $10^{-5}$ or $10^{-6}$ cancers per year from all pathways. Exposed individual is the site user or site resident.

$\begin{array}{lllllllllll}\text { Year } & 0 & 1 & 3 & 10 & 30 & 50 & 100 & 300 & 500 & 1000\end{array}$

Hunting Scenario, Average Concentrations $\left(\mathrm{x} 10^{-6}\right)$

$\begin{array}{lllllllllll}\text { Site User } & 3.4 & 3.4 & 3.2 & 2.6 & 1.5 & 0.85 & 0.16 & 0.02 & 0.02 & 0.02\end{array}$

Hunting Scenario, 35 pCi/g Soil Concentration

$\left(\times 10^{-5}\right)$

$\begin{array}{lllllllllll}\text { Site User } & 1.6 & 1.6 & 1.5 & 1.2 & 0.7 & 0.4 & 0.08 & 0.001 & 0.001 & 0.001\end{array}$

Farming Scenario \#1, Average Concentrations

\begin{tabular}{lllllllllll} 
& \multicolumn{1}{c}{$\left(\mathrm{x} 10^{-5}\right)$} \\
Site Resident & 1.4 & 1.3 & 1.3 & 1.1 & 0.6 & 0.4 & 0.06 & 0.02 & 0.02 & 0.17
\end{tabular}

Farming Scenario \#1, 35 pCi/g Soil Concentration $\left(\times 10^{-5}\right)$

Site Resident

$6.4 \quad 9.3$

$13.4 \quad 19.2$

20.7

$20.7 \quad 20.8 \quad .001$

.002

.002

Farming Scenario \#2, Average Concentrations

(x 10-5)

$\begin{array}{lllllllll}\text { Site Resident } & 1.4 & 8.5 & 18.8 & 33.3 & 37.0 & 37.0 & 37.2 & .02\end{array}$

$.02 \quad .03$

Farming Scenario \#2, 35 pCi/g Soil Concentration

Farming Scenario \#2, $35 \mathrm{pCi} / \mathrm{g}$
$\left(\times 10^{-5}\right)$

$\begin{array}{lllllllllll}\text { Site Resident } & 6.4 & 41.9 & 93.2 & 165.9 & 184.3 & 185.0 & 185.0 & 0.01 & 0.01 & 0.01\end{array}$ 


\section{CONCLUSIONS}

Models of the terrestrial ecosystem at JPG have been developed and show that human uptake of DU through different pathways is possible. The models also suggest that the doses to humans are small except in the case of extremely high and unrealistic DU concentrations in soils and waters. Sensitivity analyses of the models indicate that DU concentrations in soils, waters, and in or on plants are important to environmental transport of DU. In addition, the sensitivity analysis showed that the area of contamination, the biomass of plants consumed by animals, and the rate at which DU is washed off the plants surfaces are also of importance. Finally, the concentration of dust in the air and, therefore, the amount of airborne DU, play an important role when humans live on the site and/or use the land as a farm.

Doses to humans estimated from the RESRAD model indicate that the $100 \mathrm{mrem} / \mathrm{year}$ exposure limit is exceeded only when the impact area is farmed and all drinking water is obtained from the shallow aquifer on site (i.e., farming scenario \#2). DU in drinking water dominated the dose estimates when the exposure limits were exceeded. In the hunting scenario and farming scenario \#1, the RESRAD model showed that the DU concentration in the air and, therefore, on the surface of vegetation, played the important role in doses to humans. Significant uncertainty in the dose estimates can be reduced by measuring DU concentrations in water, dust, and soil and the temporal or spatial variability in each measurement. Figures $9,11,12$, and 15 show the amount of variation in estimated doses due to uncertainty in the dust loading values used in the RESRAD simulations.

Removal of DU fragments on the surface of soils in the impact area would reduce the total amount of DU available for transport through the various environmental pathways. However, subsurface recovery of DU would result in increased airborne DU concentrations, damage to the ecosystem at JPG as a result of damage to soils, and could increase erosion of DUcontaining soil and thereby increase the water concentration of DU. A risk-based approach to specific remediation activities is suggested so that the reduction in risk due to a particular landuse scenarios can be evaluated before it is implemented. 


\section{REFERENCES}

Abbott, D. L. et al, 1983. Summary of Data and Environmental Monitoring Plan, Jefferson Proving Ground. Internal report, not published.

DOE, 1988. Internal Dose Conversion Factors for Calculation of Dose to the Public. Report DOE/EH-0071, DE 88-014297, U. S. Department of Energy.

Gilbert, T. L. et al, 1989. A Manual for Implementing Residual Radioactive Material Guidelines, Report ANL/ES-160 (DOE/CH/8901), Argonne National Laboratory. Hoffman, F. O., and Baes, C. F. , 1979. A Statistical Analysis of Selected Parameters for Predicting Food Chain Transport and Internal Doses of Radionuclides. Report NUREG/CR-1004. Oak Ridge National Laboratory.

Ibrahim, S. A., and Whicker, F. W., 1988. Comparative Uptake of U and Th by Native Plants at a.U Production Site. Health Physics, 54, 413-419.

ICRP, 1990. Recommendations of the International Council on Radiation Protection, Publication \#60. Vol. 21 (1-3).

NCRP, 1984. Radiological Assessment: Predicting the Transport, Bioaccumulation, and Uptake by Man of Radionuclides Released to the Environment. NCRP Report 76, National Council on Radiation Protection and Measurements, Bethesda.

Price, K., 1991. The Analysis of Soil and Vegetation Samples Collected from the Yuma Proving Ground. Report TD 2761, Pacific Northwest Laboratory.

Sehmel, G. A., 1980. Particle Resuspension: A Review. Environment International 4, 107-127. Yu, C., Zeilen, A. J., Cheng, J.-J., Yuan, Y. C., Jones, L. G., Lepoire, D. J., Wang, Y. Y., Loureiro, C. O., Gnanapragasam, E., Faillace, E., Wallo, A., Williams, W. A., and Peterson, H., 1993. Manual for Implementing Residual Radioactive Material Guidelines Using RESRAD 5.0. Argonne National Laboratory. 
APPENDIX A

PARAMETER VALUES AND DISTRIBUTIONS FOR THE STEADY-STATE MODEL 
Parameters for Steady State Model

BCF, soil to plants, $B_{1}$

Uniform distribution with parameters:

Minimum

2.90E-04 (unitless)

Maximum 2.50E-03

Selected range is from $2.90 \mathrm{E}-4$ to $2.50 \mathrm{E}-3$

Mean value in simulation was $1.39 \mathrm{E}-3$

Plant Density, $\mathrm{P}$

Triangular distribution with parameters:

$\begin{array}{lll}\text { Minimum } & 150.00 & \left(\mathrm{~kg} / \mathrm{m}^{2}\right) \\ \text { Likeliest } & 240.00 & \\ \text { Maximum } & 300.00 & \end{array}$

Selected range is from 150.00 to 300.00

Mean value in simulation was 230.03

Build-up time, years, tb

Uniform distribution with parameters:

Minimum

5.00 (years)

Maximum $\quad 20.00$

Selected range is from 5.00 to 20.00

Mean value in simulation was 12.51

\section{Groundwater flow velocity $V w$}

Uniform distribution with parameters:

$\begin{array}{lrl}\text { Minimum } & 2.00 \\ \text { Maximum } & 25.00\end{array}$

Selected range is from 2.00 to 25.00

Mean value in simulation was 13.56

Rooting zone depth, ds

Uniform distribution with parameters:

$\begin{array}{lll}\text { Minimum } & 10.00 & (\mathrm{~cm}) \\ \text { Maximum } & 40.00\end{array}$

Selected range is from 10.00 to 40.00

Mean value in simulation was 25.08 
Soil bulk density, rho

Normal distribution with parameters:

$\begin{array}{lll}\text { Mean } & 1.50 \quad\left(\mathrm{~g} / \mathrm{cm}^{3}\right) \\ \text { Standard } & 0.15\end{array}$

Dev.

Selected range is from -Infinity to +Infinity Mean value in simulation was 1.50

Soil Moisture, theta

Uniform distribution with parameters:

$\begin{array}{lll}\text { Minimum } & 0.25 & (\mathrm{~cm} / \mathrm{cm}) \\ \text { Maximum } & 0.45\end{array}$

Selected range is from 0.25 to 0.45

Mean value in simulation was 0.35

Distribution coefficient, Kdi

Uniform distribution with parameters:

$\begin{array}{lr}\text { Minimum } & 10.00 \\ \text { Maximum } & 300.00\end{array} \quad(\mathrm{ml} / \mathrm{g})$

Selected range is from 10.00 to 300.00

Mean value in simulation was 154.97

Soil Surface Conc., Cs

Uniform distribution with parameters:

$\begin{array}{lr}\text { Minimum } & 10.00 \quad(\mathrm{pCi} / \mathrm{g}) \\ \text { Maximum } & 100.00\end{array}$

Selected range is from 10.00 to 100.00

Mean value in simulation was 54.96

Soil Ingestion Rate, g/day, Qs

Uniform distribution with parameters:

$\begin{array}{lll}\text { Minimum } & 30.00 & \text { (g/day) } \\ \text { Maximum } & 60.00\end{array}$

Selected range is from 30.00 to 60.00

Mean value in simulation was 44.95 
Fraction of water from contaminated source, fw
Uniform distribution with parameters:

$$
\begin{array}{lr}
\text { Minimum } & 1.00 \mathrm{E}-01 \\
\text { Maximum } & 1.00 \mathrm{E}+00
\end{array}
$$

Selected range is from $1.00 \mathrm{E}-1$ to $1.00 \mathrm{E}+0$

Mean value in simulation was $5.49 \mathrm{E}-1$

\section{Water Consumption, Qw}

Uniform distribution with parameters:

$$
\begin{array}{lll}
\text { Minimum } & 2.00 \mathrm{E}+01 & \text { (1/day) } \\
\text { Maximum } & 6.00 \mathrm{E}+01
\end{array}
$$

Selected range is from $2.00 \mathrm{E}+1$ to $6.00 \mathrm{E}+1$ Mean value in simulation was $4.01 \mathrm{E}+1$

\section{Water Concentration, $\mathrm{Cw}$}

Lognormal distribution with parameters:

$\begin{array}{lll}\text { Mean } & 3.00 \mathrm{E}+00 \quad(\mathrm{pC} / \mathrm{l}) \\ \text { Standard } & 5.00 \mathrm{E}+00 \\ \text { Dev. } & \end{array}$

Selected range is from $0.00 \mathrm{E}+0$ to + Infinity Mean value in simulation was $2.88 \mathrm{E}+0$

Frequency on pasture, $\mathrm{fp}$

Uniform distribution with parameters:

$\begin{array}{ll}\text { Minimum } & 0.00 \text { (unitless) } \\ \text { Maximum } & 1.00\end{array}$

Selected range is from 0.00 to 1.00

Mean value in simulation was 0.50

Uniform distribution with parameters:

$\begin{array}{ll}\text { Minimum } & 0.00 \text { (unitless) } \\ \text { Maximum } & 1.00\end{array}$

Fraction of food that is contaminated, is
Selected range is from 0.00 to 1.00

Mean value in simulation was 0.50 
Fraction of Impact Area in Resuspension

Uniform distribution with parameters:

Minimum

Maximum

0.01 (unitless)

0.10

Selected range is from 0.01 to 0.10

Mean value in simulation was 0.06

Fraction was 1.0 when entire impact area used

\section{Fraction of Area in}

Resuspension

Uniform distribution with parameters:

Minimum

Maximum

0.01 (unitless)

0.10

Selected range is from 0.01 to 0.10

Mean value in simulation was 0.05

Interception fraction, fr

Uniform distribution with parameters:

Minimum

Maximum

0.00 (unitless)

1.00

Selected range is from 0.00 to 1.00

Mean value in simulation was 0.50

Translocation factor, $\mathrm{TV}$

Uniform distribution with parameters:

Minimum $\quad 0.00$ (unitless)

Maximum $\quad 1.00$

Selected range is from 0.00 to 1.00

Mean value in simulation was 0.50

Biomass at Harvest, Yv
Triangular distribution with parameters:

$\begin{array}{lll}\text { Minimum } & 0.20 & \left(\mathrm{~kg} / \mathrm{m}^{2}\right) \\ \text { Likeliest } & 2.00 & \\ \text { Maximum } & 2.20 & \end{array}$

Selected range is from 0.20 to 2.20

Mean value in simulation was 1.46 
Weathering time, tw

Normal distribution with parameters:

$\begin{array}{lrl}\text { Mean } & 14.00 & \text { (day) } \\ \text { Standard } & 4.00\end{array}$

Dev.

Selected range is from -Infinity to +Infinity Mean value in simulation was 14.00

\section{Time of Crop exposure, te}

Normal distribution with parameters:

$\begin{array}{lll}\text { Mean } & 60.00 & \text { (day) } \\ \text { Standard } & 10.00 & \\ \text { Dev. } & \end{array}$

Selected range is from -Infinity to +Infinity Mean value in simulation was 59.89 
APPENDIX B

PARAMETER VALUES FOR

RESRAD CALCULATIONS 
Input Data for hunting scenario, average soil concentrations. 
Reaidual Radioactivity Program, Version 5.00

04/04/94 20:52 Page 4

Pile: HUNT.DAT

site-specific Parameter summary

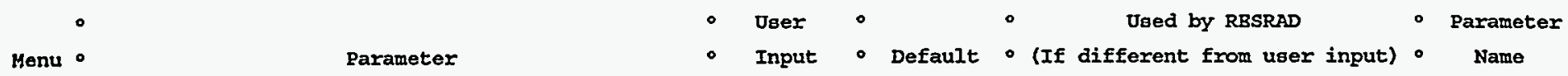

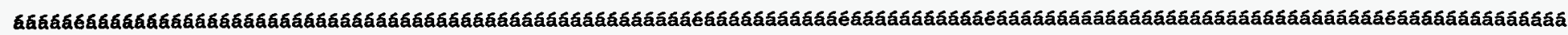

R011 - Area of contaminated zone $(m * * 2)$

Ro11 Thickeness of contaminated zone (m)

R011 - Length parallel to aquifer flow (m)

R011 - Basic radiation dose limit (mrem/yr)

R011 - Time aince placement of material (yr)

R011 - Times for calculations $(y x)$

R011 - Times for calculations ( $y x)$

ro11 - Times for calculations (yx)

R011 - Times for calculations (yx)

R011 - Times for calculations (yr)

R011 - Times for calculations $(y x)$

R011 - Times for calculations (yr)

R011 - Times for calculations ( $y x)$

R011 Times for calculations (yr)

-

R012 - Initial principal radionuclide (pci/g): U-234

R012 - Initial principal radionuclide (pCi/g): U-238

R012 - Concentration in groundwater

R012 - Concentration in groundwater

(pCi/L): $0-234$

(pCi/L): $\quad 0-238$

- $1.000 B+06 \circ 1.000 B+04 \circ$

- 1.5008-01 $2.0008+00 \circ$

- $1.500 \mathrm{~B}+03 \circ 1.000 \mathrm{~B}+02$ 。

- $1.0008+02 \circ 3.000 \mathrm{~B}+01$.

- $1.500 \mathrm{~B}+01 \cdot 0.000 \mathrm{~B}+00$ 。

- $1.000 \mathrm{~B}+00 \circ 1.000 \mathrm{~B}+00$ 。

- 3.000B+00 $3.000 \mathrm{~B}+00$ 。

- $1.000 \mathrm{~B}+01 \circ 1.000 \mathrm{~B}+01$ 。

- 3.000B+01 3.000B+01。

- 5.000B+01 $01.000 \mathrm{~B}+02$ 。

- $1.000 \mathrm{~B}+02 \circ 3.000 \mathrm{~B}+02 \circ$

- 3.000B+02 $01.000 \mathrm{~B}+03 \circ$

- 5.000B+02 $03.000 \mathrm{~B}+03 \circ$

- $1.000 \mathrm{~B}+03 \circ 1.000 \mathrm{~B}+04 \circ$

$\circ$

- $1.610 \mathrm{~B}+00 \circ 0.000 \mathrm{~B}+00 \circ$

- $6.990 \mathrm{~B}+00 \circ 0.000 \mathrm{~B}+00 \circ$

- not used $0.000 \mathrm{~B}+00^{\circ}$

- not used $0.000 \mathrm{~B}+00^{\circ}$

$\circ$

- $0.000 \mathrm{~B}+00 \cdot 0.000 \mathrm{~B}+00 \circ$

- not used $-1.500 \mathrm{~B}+00 \circ$

- not used $\circ 1.000 \mathrm{~B}-03$.

- $1.500 \mathrm{~B}+00 \circ 1.500 \mathrm{~B}+00$ 。

- $1.000 \mathrm{~B}-03 \circ 1.000 \mathrm{~B}-03 \circ$

-4.000B-01 4.000B-01

- 3.0008-01 2.000B-01。

- $1.000 \mathrm{~B}+01 \circ 1.000 \mathrm{~B}+01$.

- 5.300B+00 $5.300 \mathrm{~B}+00 \circ$

- not used $8.000 \mathrm{~B}+00 \circ$

- 6.000B-01 5.000B-01 。

- $1.000 \mathrm{~B}+00 \circ 1.000 \mathrm{~B}+00 \circ$

- $0.000 \mathrm{~B}+00 \circ 2.000 \mathrm{~B}-01$.

- overhead o overhead 0

- 4.000B-01 $02.000 \mathrm{~B}-01 \circ$

- $1.000 \mathrm{~B}+06 \circ 1.000 \mathrm{~B}+06$ 。

-1.0008-03 $01.0008-03 \circ$

$\circ$

- $1.500 \mathrm{~B}+00 \circ 1.500 \mathrm{~B}+00 \circ$

-4.000B-01 4.000B-01 $\circ$

- 3.0008-01 2.0008-01

- $1.000 \mathrm{~B}+02 \cdot 1.000 \mathrm{~B}+02$ 。

- 2.0008-02 $\circ 2.000 \mathrm{~B}-02 \circ$

- $5.300 \mathrm{~B}+00 \circ 5.300 \mathrm{~B}+00$ ○

$: 1.000 \mathrm{~B}-03 \circ 1.000 \mathrm{~B}-03 \circ$

- $1.0008+01 \circ 1.0008+01 \circ$

- ND 0 ND

- not used $\circ 2.500 \mathrm{~B}+02 \circ$

$\circ 101$

R015 Number of unsaturated zone strata
- arba

- thicko

- lczpar

- BRLD

- TI

- $T$ ( 2)

- $T$ ( 3)

- $T(4)$

- $T$ ( 5)

- $T(6)$

- $T(7)$

- $T(8)$

- $T$ ( 9)

- $T(10)$

$\circ$

- s1 (4)

- S1 ( 5)

- ผ1 (4)

- W1 ( 5)

$\circ$

- COVBRO

- DENSCV

- VCV

- DENSCz

- vcz

- TPCZ

- BPCZ

- $\mathrm{HCCZ}$

- BCZ

- HUMID

- BVAPTR

- prBCrP

- RI

- IDITCH

- RUNofa

- harba

- BPS

$\circ$

- DBNSAR

- TPSZ

- BPSZ

- HCSZ

- HGWr

- BSZ

- VWT

- DWIBWT

- MODBL

- UW

-

- NS 


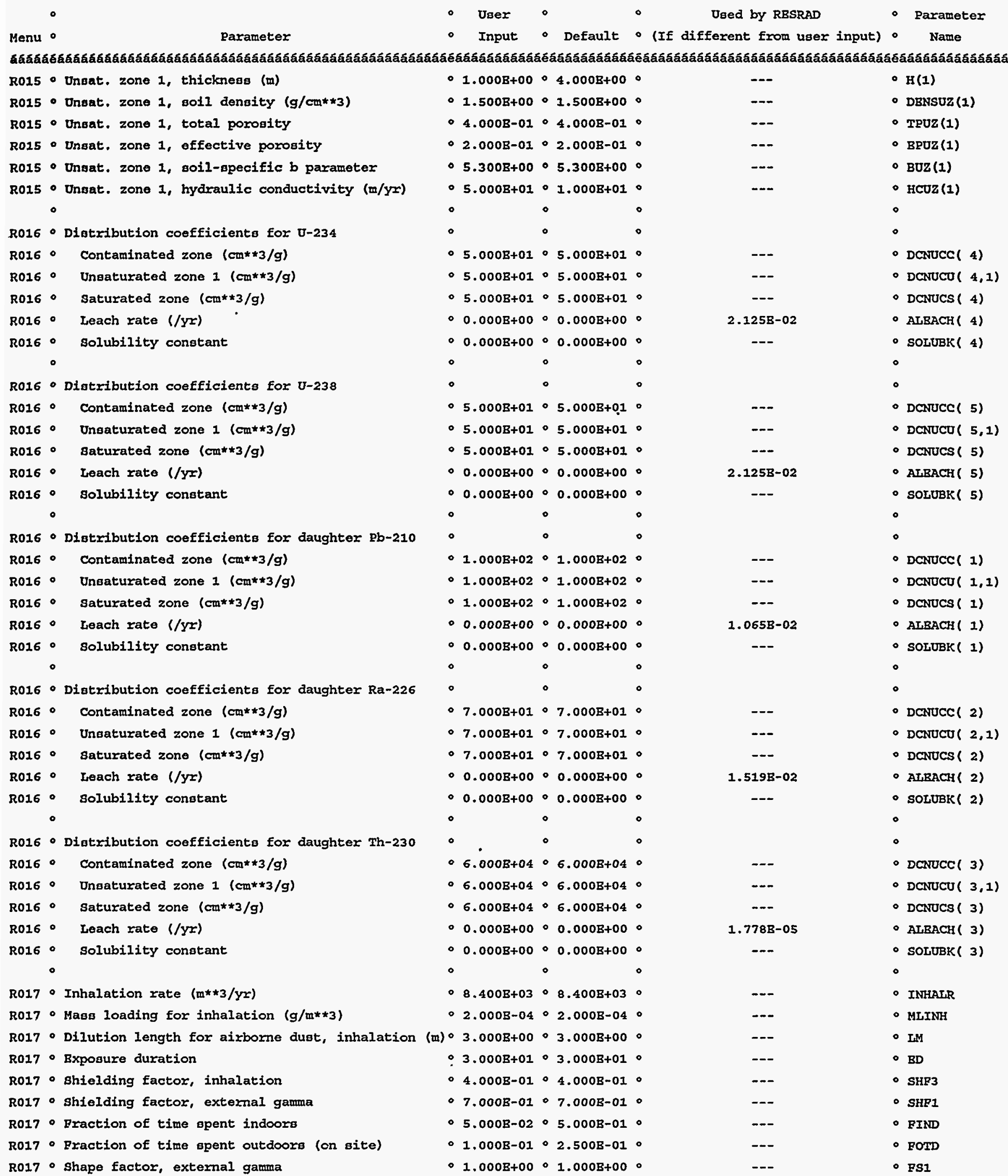




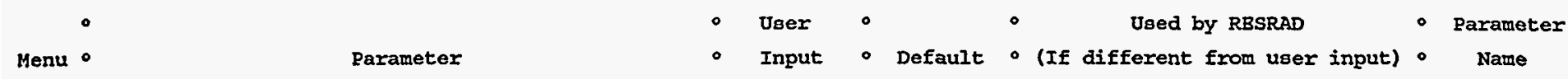

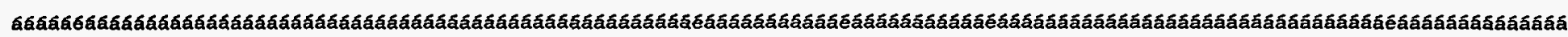

R017 - Fractions of annular areas within ARBA:

R017. Outer annular radius $(m)=<(1 / \nexists)$

R017 Outer annular radius (m) $=\propto(10 / 9)$

R017 O Outer annulax radius $(m)=<(20 / \boxminus)$

R017 - Outer annular radius $(m)=<(50 / 9)$

R017 - Outer annular radius $(m)=<(100 / 9)$

R017 - Outer annular radius $(m)=<(200 / \oplus)$

R017 O Outer annular radius $(m)=\alpha(500 / \nexists)$

R017 O Outer annular radius $(m)=\alpha(1000 / \boxminus)$

R017 - Outer annular radius $(m)=c(5000 / \oplus)$

R017 O Outer annular radius $(m)=\alpha(1 . B+04 / \boxminus)$

R017 O Outer annular radius $(m)=\alpha(1 . B+05 / \oplus)$

R017 Outer annular radius $(m)=\alpha(1 . B+06 / \boxminus)$

R018 Pruita, vegetables and grain consumption (kg/yr) $0.000 \mathrm{~B}+00 \circ 1.600 \mathrm{~B}+02 \circ$

R018 - Leafy vegetable consumption $(\mathrm{kg} / \mathrm{yr})$

R018 Hilk coneumption ( $\mathrm{L} / \mathrm{Yr}$ )

R018 - Meat and poultry consumption $(\mathrm{kg} / \mathrm{yr})$

R018 - Bieh consumption $(\mathrm{kg} / \mathrm{yr})$

R018 - Other Beafood consumption $(\mathrm{kg} / \mathrm{yr})$

R018 - soil ingestion rate $(g / y r)$

R018 - Drinking water intake $(\mathrm{L} / \mathrm{Y} Y)$

R018 - Contamination fraction of drinking water R018 - Contamination fraction of household water R018 - Contamination fraction of livestock water R018 - Contamination fraction of irrigation water R018 - Contamination fraction of aquatic food R018 - Contamination fraction of plant food R018 - Contamination fraction of meat

R018 - Contamination fraction of milk

-

R019 - Livestock fodder intake for meat ( $\mathrm{kg} /$ day)

R019 - Livestock fodder intake for milk (kg/day) R019 - Livestock water intake for meat (L/day) R019 - Livestock water intake for milk (L/day) R019 - Livestock soil intake ( $\mathrm{kg} /$ day)

R019 - Mass loading for foliar deposition ( $g / m * \star 3)$

R019 Depth of boil mixing layer (m)

R019 - Depth of roots (m)

R019 - Drinking water fraction fxom ground water

R019 O Household water fraction from ground water

R019 Livegtock water fxaction from ground water

R019 - Irrigation fxaction from ground watex

-

C14 - $\mathrm{C}-12$ concentration in water $(\mathrm{g} / \mathrm{cm} \star 3)$

C14 - C-12 concentration in contaminated soil ( $(\mathrm{g} / \mathrm{g})$

C14 - praction of vegetation carbon from soil

C14 Praction of vegetation carbon from air

C14 - C-14 evasion layer thickness in soil (m)

C14 C-14 evasion flux rate from soil (1/sec)

C14 $\mathrm{C}-12$ evasion flux rate from soil ( $1 / \mathrm{sec}$ )

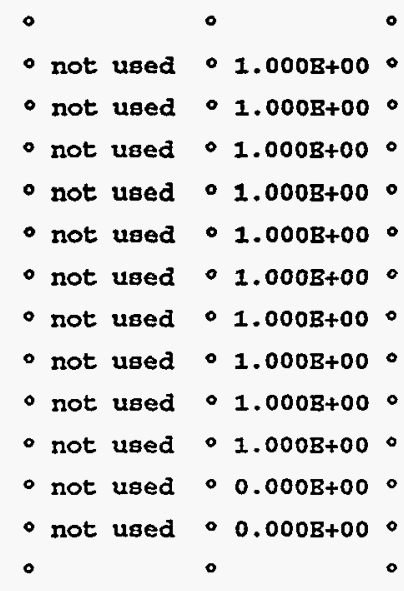

- $0.000 \mathrm{~B}+00 \circ 1.400 \mathrm{~B}+01 \circ$

- not used $\circ 9.200 B+01$.

- $9.200 \mathrm{~B}+01 \circ 6.300 \mathrm{~B}+01$ 。

-5.400B+00 5.400B+00。

- $0.000 \mathrm{~B}+00 \circ 9.000 \mathrm{~B}-01 \circ$

$\circ 3.650 \mathrm{~B}+01 \circ 3.650 \mathrm{~B}+01 \circ$

- $0.000 \mathrm{~B}+00 \circ 5.100 \mathrm{~B}+02 \circ$

- $0.000 \mathrm{~B}+00 \circ 1.000 \mathrm{~B}+00 \circ$

- $1.000 \mathrm{~B}+00 \circ 1.000 \mathrm{~B}+00$ 。

- $1.000 \mathrm{~B}+00 \circ 1.000 \mathrm{~B}+00 \circ$

- $1.000 \mathrm{~B}+00 \circ 1.000 \mathrm{~B}+00 \circ$

- 1.000B-01 5.000B-01。

$0-1 \quad 0-1$ 。

$0-1 \quad 0-1$ 0

- not used $0-1$ ०

- 0 。

-4.000B+01⒍800B+01。

- not used $5.500 \mathrm{~B}+01$.

- 5.500B+01 5.000B+01。

- not used $\circ 1.600 \mathrm{~B}+02$.

- 5.000B-01 5.000B-01

- 1.000B-03॰1.000B-04。

- 1.500B-01・1.500B-01。

- 9.000B-01 9.000B-01。

- $0.000 \mathrm{~B}+00 \circ 1.000 \mathrm{~B}+00 \circ$

- $0.000 \mathrm{~B}+00 \circ 1.000 \mathrm{~B}+00 \circ$

- $1.000 \mathrm{~B}+00 \circ 1.000 \mathrm{~B}+00$ 。

- $0.000 \mathrm{~B}+00 \circ 1.000 \mathrm{~B}+00 \circ$

$\circ$

- not used $2.000 \mathrm{~B}-05 \circ$

$\therefore$ not used $\circ 3.000 \mathrm{~B}-02 \circ$

- not used $\circ 2.000 \mathrm{~B}-02 \circ$

- not used $\circ 9.800 \mathrm{~B}-01$.

- not used $\circ 3.000 \mathrm{~B}-01$.

- not used $\circ 7.000 \mathrm{~B}-07^{\circ}$

- not ueed $\circ 1.000 \mathrm{~B}-10^{\circ}$
-

- $\operatorname{praca}(1)$

- pracal 2)

- eracal 3)

- bracal 4)

- $\operatorname{mraca}(5)$

- pracal 6)

- bracal 7)

- pracal 8)

- $\operatorname{praca}(9)$

- eraca(10)

- eraca(11)

- $\operatorname{PRACA}(12)$

-

- DIBT(1)

- DIET(2)

- DIBT(3)

- DIBT(4)

- DIET (5)

- DIBT(6)

- sorr

- DWI

- FDW

- FHнH

- PIW

- FIRW

- ER9

- FPLANT

- fMBar

- FMIJK

-

- IPI5

- IPI6

- IWI5

- IWI6

- ISI

- MIFD

- DM

- DROOT

- EGHDH

- FGNHH

- FGWLW

- pGWIR

$\circ$

- C12WTR

- C12C2

- csorr

- carr

- DNC

- BVSN

- RBVSN 


\begin{tabular}{|c|c|c|c|c|c|c|}
\hline Menu & Parameter & $\begin{array}{ll}- & \text { User } \\
- & \text { Input }\end{array}$ & - Default & $\begin{array}{l}\text { - } r e d ~ \\
\circ \text { (If different }\end{array}$ & $\begin{array}{l}\text { by RBSRAD } \\
\text { from user input) }\end{array}$ & $\begin{array}{l}\text { - } \quad \text { Parameter } \\
\text { - } \quad \text { Name }\end{array}$ \\
\hline Gááát & 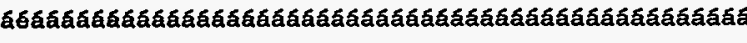 & 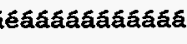 & 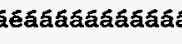 & 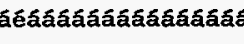 & 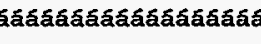 & 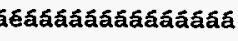 \\
\hline C14 & - Eraction of grain in beef cattle feed & - not used & $.8 .000 \mathrm{~B}-01$ & $\bullet$ & -- & - AVFG4 \\
\hline C14 & - Fraction of grain in milk cow feed & - not used & $\begin{array}{l}.000 B-01 \\
.\end{array}$ & $\begin{array}{l}\circ \\
\circ\end{array}$ & -- & - AVFG5 \\
\hline R021 & - Thickness of building foundation ( $m$ ) & $01.500 \mathrm{~B}-01$ & - $1.500 \mathrm{~B}-01$ & $\bullet$ & -- & - FLOOR \\
\hline R021 & - Bulk density of building foundation $(\mathrm{g} / \mathrm{cm} * * 3)$ & - $2.400 \mathrm{~B}+00$ & $02.400 \mathrm{~B}+00$ & ० & -.- & - DBNSEL \\
\hline R021 & - Total porosity of the cover material & - not used & $04.000 \mathrm{~B}-01$ & $\bullet$ & -- & - TPCV \\
\hline R021 & - Total porosity of the building foundation & $\circ 1.000 \mathrm{~B}-01$ & $\cdot 1.0008-01$ & $\bullet$ & -- & - TPFL \\
\hline R021 & - Volumetric water content of the cover material & - not used & . $5.000 \mathrm{~B}-02$ & $\bullet$ & -- & - PH2OCV \\
\hline R021 & - Volumetric water content of the foundation & $.3 .0008-02$ & $\circ 3.0008-02$ & $\bullet$ & -- & - PH2ORL \\
\hline R021 & - Diffusion coefficient for radon gas (m/sec): & $\bullet$ & $\bullet$ & $\circ$ & & $\circ$ \\
\hline R021 & - in cover material & - not used & $.2 .0008-06$ & $\circ$ & -- & - DIFCV \\
\hline R021 & - in foundation material & $\cdot 3.000 \mathrm{~B}-07$ & $03.000 \mathrm{~B}-07$ & 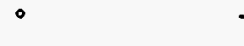 & $\cdots$ & - DIFEL \\
\hline R021 & - in contaminated zone soil & $.2 .0008-06$ & $.2 .0008-06$ & - & -- & - DIFCZ \\
\hline R021 & - Radon vertical dimension of mixing (m) & $.2 .000 \mathrm{~B}+00$ & $.2 .000 \mathrm{~B}+00$ & $\circ$ & $\cdots$ & - HMIX \\
\hline R021 & - Average annual wind speed (m/sec) & $.2 .000 \mathrm{~B}+00$ & $.2 .000 \mathrm{~B}+00$ & - & --- & - WIND \\
\hline R021 & - Average building air exchange rate $(1 / h x)$ & $5.000 \mathrm{~B}-01$ & $.5 .000 \mathrm{~B}-01$ & $\circ$ & $\cdots$ & - REXG \\
\hline R021 & - Height of the building (room) (m) & $\cdot 2.5008+00$ & $.2 .500 B+00$ & $\circ$ & -- & - HRM \\
\hline R021 & - Building interior area factor & $0.000 \mathrm{~B}+00$ & $0.000 B+00$ & - code computed & (time dependent) & - BAI \\
\hline R021 & - Building depth below ground surface (m) & $-1.000 \mathrm{~B}+00$ & $.1 .000 \mathrm{~B}+00$ & $\cdot$ & -- & - DMFL \\
\hline R02I & - Bmanating power of Rn-222 gas & $.2 .500 \mathrm{~B}-01$ & $02.5008-01$ & $\circ$ & -- & - BUANA (1) \\
\hline R021 & - Bmanating power of Rn-220 gas & - not used & $01.500 \mathrm{~B}-01$ & - & -- & - $\operatorname{BMANA}(2)$ \\
\hline
\end{tabular}

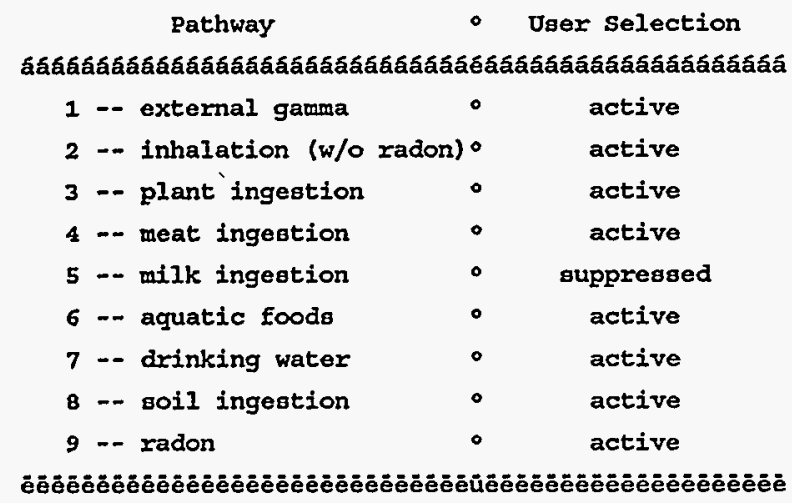


Input data for hunting scenario, $35 \mathrm{pCi} / \mathrm{g}$ soil concentration. 


\begin{tabular}{|c|c|c|c|c|c|}
\hline Menu & Parameter & $\begin{array}{ll}- & \text { User } \\
- & \text { Input }\end{array}$ & - Default & $\begin{array}{l}\text { - Used by RBSRAD } \\
\text { - (If different from user input) }\end{array}$ & $\begin{array}{l}\text { - } \quad \text { Parameter } \\
\text { - Name }\end{array}$ \\
\hline Gáák & 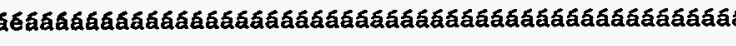 & 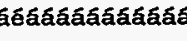 & 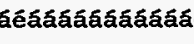 & 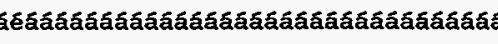 & 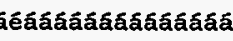 \\
\hline R015 & - Number of unsaturated zone strata & - 1 & $\circ 1$ & -- & - NS \\
\hline R015 & - Uneat. zone 1, thicknese (m) & - $1.000 \mathrm{~B}+00$ & $\circ 4.0008+00$ & --- & - $H(1)$ \\
\hline R015 & - Unsat. zone 1 , soil density $(\mathrm{g} / \mathrm{cm} * * 3)$ & - $1.500 \mathrm{~B}+00$ & $\circ 1.500 \mathrm{~B}+00$ & --- & - DBNSUZ (1) \\
\hline $\mathbf{R 0 1 5}$ & - Unsat. zone 1, total porosity & - 4.000B-01 & - 4.0008-01 & --- & - TPUZ (1) \\
\hline R015 & - Unoat. zone 1, effective porosity & - 2.000B-01 & $\cdot 2.000 B-01$ &.- & - EPUZ(1) \\
\hline R015 & - Ungat. zone 1, soil-specific b parameter & - $5.300 \mathrm{~B}+00$ & - $5.300 \mathrm{~B}+00$ & --- & - $\mathrm{BUZ}(1)$ \\
\hline R015 & $\begin{array}{l}\text { - Ongat. zone } 1 \text {, hydraulic conductivity }(\mathrm{m} / \mathrm{y} x) \\
\text { - }\end{array}$ & 5.000B+01 & - $1.000 \mathrm{~B}+01$ & 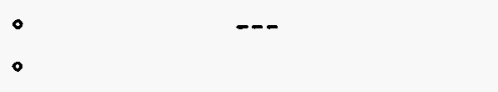 & - $\operatorname{Hcuz}(1)$ \\
\hline R016 & - Distribution coefficients for $0-234$ & $\bullet$ & $\bullet$ & $\bullet$ & - \\
\hline R016 & - Contaminated zone $(\mathrm{cm} * * 3 / \mathrm{g})$ & $\circ 5.000 \mathrm{~B}+01$ & $05.0008+01$ & $m$ & - DCNUCC ( 6$)$ \\
\hline R016 & - Ungaturated zone $1(\mathrm{~cm} \star \star 3 / \mathrm{g})$ & $\circ 5.0008+01$ & $.5 .000 \mathrm{~B}+01$ & --- & - DCNucu $(6,1)$ \\
\hline R016 & - Saturated zone $(\mathrm{cm} * 3 / \mathrm{g})$ & $\circ 5.000 \mathrm{~B}+01$ & - $5.000 \mathrm{~B}+01$ & 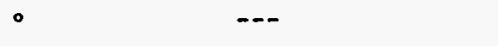 & - DCNUCS( 6 ) \\
\hline R016 & - Leach rate $(/ y x)$ & $0.000 \mathrm{~B}+00$ & $0.000 \mathrm{~B}+00$ & 2.125B-02 & - ALBACH ( 6) \\
\hline R016 & - Solubility constant & $0.000 \mathrm{~B}+00$ & $0.000 \mathrm{~B}+00$ & - & $\begin{array}{l}-\operatorname{SOLUBK}(6) \\
-\end{array}$ \\
\hline R016 & - Digtribution coefficients for 0-235 & $\bullet$ & $\circ$ & $\circ$ & $\bullet$ \\
\hline R016 & - Contaminated zone $(\mathrm{cm} \star * 3 / \mathrm{g})$ & $\circ 5.000 B+01$ & $.5 .000 \mathrm{~B}+01$ & -- & - DCNuCC ( 7) \\
\hline R016 & - Unvaturated zone $1(\mathrm{~cm} * * 3 / \mathrm{g})$ & $\circ 5.0008+01$ & $05.000 \mathrm{~B}+01$ & --- & - DCANJCU $(7,1)$ \\
\hline 8016 & - Saturated zone $(\mathrm{cm} * \star 3 / \mathrm{g})$ & - $5.0008+01$ & - $5.000 \mathrm{~B}+01$ & -- & - DCNUCS ( 7) \\
\hline R016 & - Leach rate (/yx) & $0.000 \mathrm{~B}+00$ & $0.000 \mathrm{~B}+00$ & $2.1258-02$ & - ALBACH ( 7) \\
\hline 8016 & Solubility constant & - $0.000 \mathrm{~B}+00$ & $\begin{array}{l}0.000 \mathrm{~B}+00 \\
-\end{array}$ & $\begin{array}{l}\circ \\
\circ\end{array}$ & - SOLUBK( 7) \\
\hline R016 & - Distribution coefficients for $0-238$ & $\bullet$ & - & $\bullet$ & $\bullet$ \\
\hline R016 & - Contaminated zone $(\mathrm{cm} * \star 3 / \mathrm{g})$ & - $5.000 \mathrm{~B}+01$ & $5.000 \mathrm{~B}+01$ & -.- & - DCNOCC ( 8) \\
\hline R016 & - Unsaturated zone $1(\mathrm{~cm} * * 3 / \mathrm{g})$ & - $5.000 \mathrm{~B}+01$ & $0.000 \mathrm{~B}+01$ & -- & - $\operatorname{DCNUCU}(8,1)$ \\
\hline R016 & Saturated zone $(\mathrm{cm} * * 3 / \mathrm{g})$ & $05.000 \mathrm{~B}+01$ & $0.000 \mathrm{~B}+01$ & --- & - DCNuCs ( 8) \\
\hline R016 & - Leach rate $(/ Y r)$ & $0.000 \mathrm{~B}+00$ & $0.000 \mathrm{~B}+00$ & $2.125 \mathrm{~B}-02$ & - ALBACH ( 8) \\
\hline R016 & - Solubility constant & - $0.000 \mathrm{E}+00$ & $0.000 \mathrm{~B}+00$ & $\begin{array}{l}\circ \\
\circ\end{array}$ & $\begin{array}{l}\text { - SOLUBK( 8) } \\
\text { - }\end{array}$ \\
\hline R016 & - Diatribution coefficients for daughter Ac-227 & $\cdot$ & $\bullet$ & • & $\bullet$ \\
\hline R016 & - Contaminated zone $(\mathrm{cm} * * 3 / g)$ & $.2 .000 \mathrm{~B}+01$ & - $2.000 B+01$ & --- & - DCNUCC $(1)$ \\
\hline R016 & - Unsaturated zone $1(\mathrm{~cm} * * 3 / \mathrm{g})$ & $02.0008+01$ & $.2 .000 \mathrm{~B}+01$ & --- & - $\operatorname{DCNUCU}(1,1)$ \\
\hline R016 & - $\quad$ saturated zone $\left(\mathrm{cm}^{* * 3 / g}\right)$ & $.2 .0008+01$ & $.2 .000 \mathrm{~B}+01$ & --- & - DCANucs (1) \\
\hline R016 & - Leach rate $(/ y x)$ & $0.000 \mathrm{~B}+00$ & $0.000 \mathrm{~B}+00$ & $5.280 \mathrm{~B}-02$ & - ALBACH (1) \\
\hline R016 & - solubility constant & $\begin{array}{l}.0 .000 \mathrm{~B}+00 \\
.\end{array}$ & $0.000 \mathrm{~B}+00$ & $\begin{array}{l}\circ \\
\circ\end{array}$ & - $\operatorname{sOLUBK}(1)$ \\
\hline R016 & - Diatribution coefficients for daughter $\mathrm{Pa-231}$ & $\circ$ & $\bullet$ & $\circ$ & • \\
\hline R016 & - Contaminated zone $(\mathrm{cm} \star * 3 / \mathrm{g})$ & $0.000 \mathrm{~B}+01$ & $.5 .0008+01$ & $\cdots$ & - DCNUCC ( 2) \\
\hline R016 & - Unsaturated zone $1(\mathrm{~cm} \star \star 3 / \mathrm{g})$ & - $5.0008+01$ & $.5 .000 B+01$ & --- & - $\operatorname{DCNUCU}(2,1)$ \\
\hline R016 & - Saturated zone $(\mathrm{cm} * * 3 / g)$ & $.5 .000 \mathrm{~B}+01$ & $5.000 \mathrm{~B}+01$ &.-- & - DCNuCs ( 2) \\
\hline R016 & - Leach rate $(/ y x)$ & $0.000 \mathrm{~B}+00$ & $0.000 \mathrm{~B}+00$ & $2.125 \mathrm{~B}-02$ & - AEBACH ( 2) \\
\hline R016 & $\begin{array}{l}\text { - Solubility constant } \\
\text { - }\end{array}$ & $\begin{array}{l}-0.000 \mathrm{~B}+00 \\
.\end{array}$ & $0.000 \mathrm{~B}+00$ & ० & $\begin{array}{l}\text { - SOLUBK( 2) } \\
\text { - }\end{array}$ \\
\hline R016 & - Diatribution coefficients for daughter $\mathrm{pb}-210$ & $\circ$ & $\circ$ & $\circ$ & $\circ$ \\
\hline R016 & - Contaminated zone $(\mathrm{cm} * * 3 / \mathrm{g})$ & $01.0008+02$ & - $1.000 \mathrm{~B}+02$ & --- & - $\operatorname{DCNUCC}(3)$ \\
\hline R016 & - Unsaturated zone $1(\mathrm{~cm} * \star 3 / \mathrm{g})$ & $\therefore 1.000 \mathrm{~B}+02$ & $1.000 \mathrm{~B}+02$ & $-\ldots$ & - $\operatorname{DCNUCU}(3,1)$ \\
\hline R016 & - Saturated zone $(\mathrm{cm} \star \star 3 / \mathrm{g})$ & $\circ 1.000 B+02$ & $\cdot 1.000 \mathrm{~B}+02$ & --- & - DCNUCS( 3 ) \\
\hline R016 & - Leach rate $(/ y x)$ & $0.000 B+00$ & $0.000 \mathrm{~B}+00$ & $1.065 \mathrm{~B}-02$ & - ALBACH ( 3) \\
\hline R016 & solubility constant & $0.000 \mathrm{~B}+00$ & $0.000 \mathrm{~B}+00$ & -- & - SOLUBK ( 3) \\
\hline
\end{tabular}




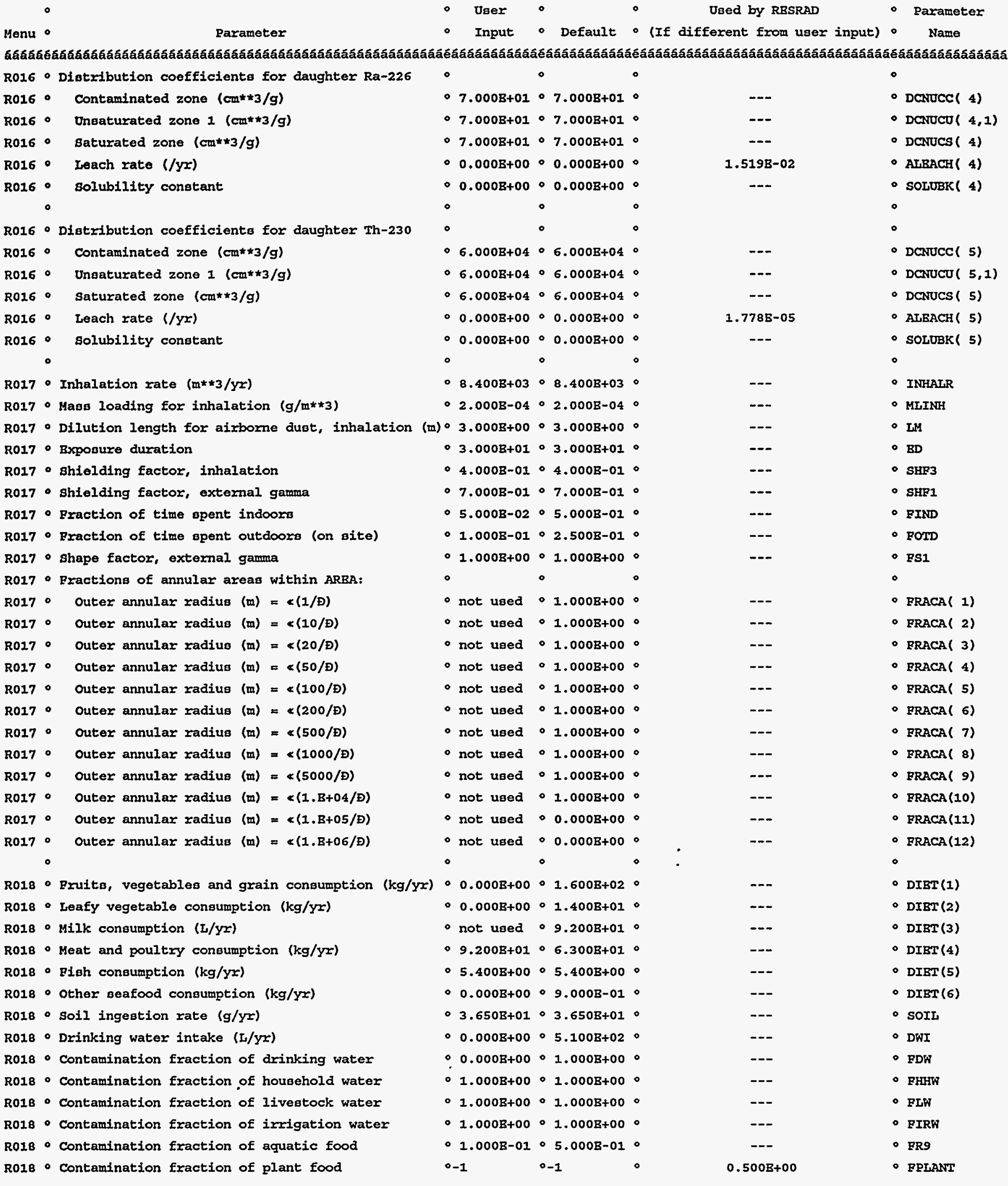


Reaidual Radioactivity Rrogram, Yersion 5.00 sumary : JPG Hunting Bcenario, $35 \mathrm{pCi} / \mathrm{g}$
04/04/94 10:14 Page 9

File: HUNT35.DAT

Site-specific Parameter summary (continued)

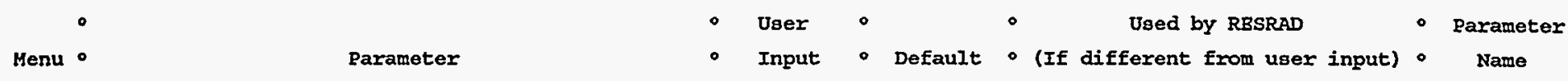

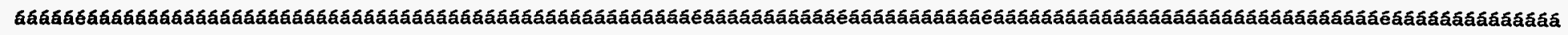

R018 - Contamination fraction of meat

R018 - Contamination fraction of milk

$0-1 \quad 0-1 \quad 0$

- not used 0-1

- 0 。

- 4.000B+01 $6.800 B+01 \circ$

- not used $05.500 \mathrm{~B}+01$ -

- 5.500B+01 $5.000 \mathrm{~B}+01$ 。

- not used $\circ 1.600 \mathrm{~B}+02$.

- 5.000B-01 5.000B-01 。

- $1.000 \mathrm{~B}-03 \circ 1.0008-04 \circ$

-1.500B-01 $01.500 \mathrm{~B}-01 \circ$

- 9.000B-01 9.000B-01。

- $0.000 \mathrm{~B}+00 \circ 1.000 \mathrm{~B}+00$ 。

- $0.000 \mathrm{~B}+00 \circ 1.000 \mathrm{E}+00$ 。

- $1.000 \mathrm{~B}+00 \circ 1.000 \mathrm{~B}+00 \circ$

- $0.000 \mathrm{~B}+00 \circ 1.000 \mathrm{~B}+00 \circ$

$\circ$

- not used $\circ 2.000 \mathrm{~B}-05^{\circ}$

- not uged $\bullet 3.000 \mathrm{~B}-02 \circ$

- not used $\circ 2.000 \mathrm{~B}-02 \circ$

- not used $\circ 9.800 \mathrm{~B}-01 \circ$

- not used $\circ 3.000 \mathrm{~B}-01 \circ$

- not used $07.000 \mathrm{~B}-07 \circ$

- not uged $01.000 \mathrm{~B}-10 \circ$

- not used $08.000 \mathrm{~B}-01$.

- not used $2.000 \mathrm{~B}-01 \circ$

- 0 。

- 1.500B-01॰1.500B-01。

- 2.400B+00॰2.400B+00。

- not used 4.000B-01

- 1.000B-01 $01.000 \mathrm{~B}-01 \circ$

- not used 0 5.000B-02

- 3.000B-02 $3.000 \mathrm{~B}-02$.

$\circ$

- not used $2.000 \mathrm{E}-06^{\circ}$

-3.000B-07 $\circ 3.000 \mathrm{~B}-07 \circ$

- 2.000B-06 2.000B-06

- $2.000 \mathrm{~B}+00 \circ 2.000 \mathrm{~B}+000$

- 2.000B+00 $2.000 \mathrm{~B}+00 \circ$

- 5.000B-01 5.000B-01

- $2.500 \mathrm{~B}+00 \circ 2.500 \mathrm{~B}+00 \circ$

- $0.000 \mathrm{~B}+00 \circ 0.000 \mathrm{~B}+00 \circ$ code computed (time dependent) $\odot \mathrm{FAI}$

- $1.000 \mathrm{~B}+00 \circ 1.000 \mathrm{~B}+00 \circ$--- DMFL

- 2.500B-01 $2.500 \mathrm{~B}-01 \circ$

- not used $\circ 1.500 \mathrm{~B}-01 \circ$

- bmana (1)

$0.1008+01$

-

--

-.. $\quad$ O LFI6

--- $\quad$ L LWI6

---

--- 0 MLFD

-.- $\quad$ DM

--- 0 DROOT

-.-

--

-.. $\quad$ BGWLW

--- $\quad$ PGHIR

(2)

- CI2hTR

- c12Cz

- csorr

- catr

- DMC

- BVSN

- RBVSN

- AVFG4

- AVFg5

$\circ$

- pLoOR

- DBNsfl

- TPCV

- TPES

- PH2OCV

- PH2OFI

$\circ$

- DIFCV

- DIFPL

- DIFCZ

- HMIX

- WIND

- REXG

- HRM

- BMANa (2) 
Input data for farming scenario \#1 (off-site drinking water), average soil concentration. 
summary : paxming scenario \#1 (no drinking water), Average Concentration

Pile : PARM1.DAT

Site-Specific Parameter Summary (continued)

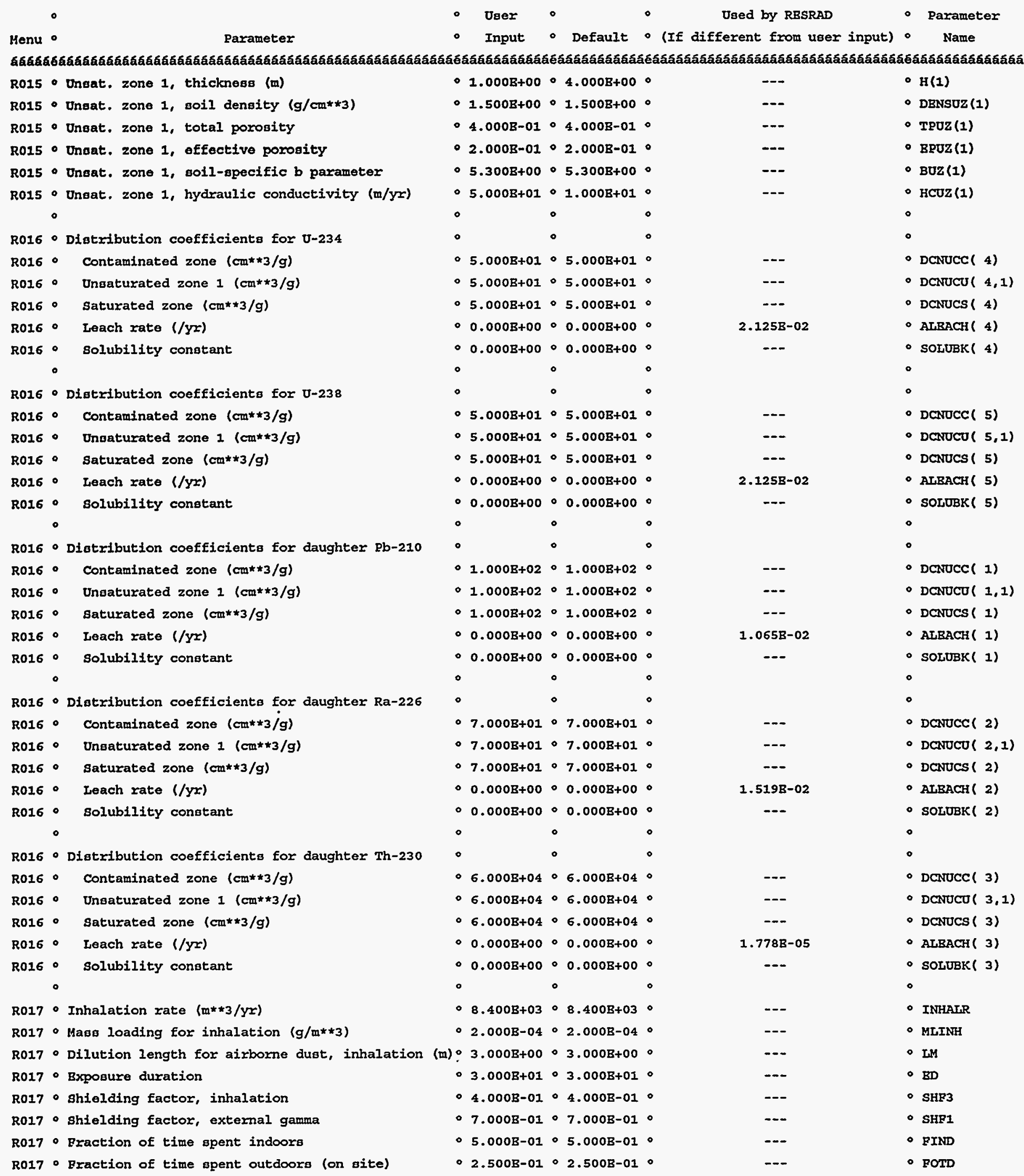




\begin{tabular}{|c|c|c|}
\hline วพם & - & $-\cdots$ \\
\hline גres & - & --- \\
\hline TIOSO & - & --- \\
\hline ZDzT & 。 & -- \\
\hline 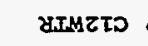 & - & $-\cdots$ \\
\hline & - & \\
\hline ХIMDA & - & --- \\
\hline MTMSA & . & --- \\
\hline HHMDA & 。 & --- \\
\hline MaMפa & - & -- \\
\hline IOOYa & 。 & --- \\
\hline พธ & - & $---^{*}$ \\
\hline बコगא & - & -- \\
\hline IST & 。 & --- \\
\hline 9IMT & - & --- \\
\hline SIMI & - & --- \\
\hline 9IaT & - & --- \\
\hline SIAT & - & --- \\
\hline & ○ & \\
\hline MTIKE & - & $\tau 0+800 \tau \cdot 0$ \\
\hline LษZKA & 。 & $\tau 0+800 \tau \cdot 0$ \\
\hline INETd A & 。 & $00+800 S^{-0}$ \\
\hline 68ส & - & --- \\
\hline MUIA & - & --- \\
\hline MTa & 。 & --- \\
\hline MHна & - & -- \\
\hline MUa & - & --- \\
\hline IMd & 。 & --- \\
\hline IIOS & - & -- \\
\hline (9) IraId & - & --- \\
\hline (s) IgIa & - & -- \\
\hline (7) Isara & - & --- \\
\hline (E) ISIa & - & -- \\
\hline (乙) IrIX & - & --- \\
\hline ( $\tau$ ) ISIa & - & --- \\
\hline & 。 & \\
\hline 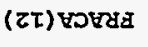 & - & $\cdots$ \\
\hline 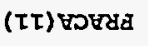 & - & --- \\
\hline 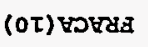 & 。 & --- \\
\hline (6) ) ४Dषd & - & -- \\
\hline (8) ) स्Dष्वa & - & --- \\
\hline 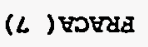 & - & --- \\
\hline (9) ) שాष्वa & - & $\therefore-$ \\
\hline (S ) सDEQA & - & --- \\
\hline (7) ) שDEda & - & -- \\
\hline (ع )षDษ્ם & - & --- \\
\hline (Z) ) ҰDYRA & ○ & --- \\
\hline (I ) YDYAd & - & -- \\
\hline & $\circ$ & \\
\hline ISA & 0 & $-\infty$ \\
\hline
\end{tabular}

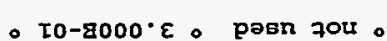

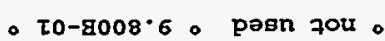

- z0-8000.z pasn zou 。

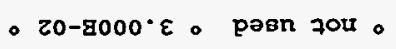

- so-g000.r o posn zou 。

- $\quad$ o

- $00+8000 \cdot \tau$ 。 $00+8000 \cdot \tau$ 。

- $00+8000^{\circ} \tau$ 。 $00+8000^{\circ} \tau$ 。

- $00+8000 . \tau$. $00+8000 . \tau$ 。

- $00+8000^{\circ} \tau$ 。 $00+8000^{\circ} 0$ 。

- T0-8000.6 \% โ0-8000.6。

- To-goos. $\tau$ 。 Lo-goos. $\tau$ 。

- $50-8000^{\circ} \tau$ 。 $\varepsilon 0-8000^{\circ} \tau$ 。

- $\tau 0-8000^{\circ} s$ o $\left[0-8000^{\circ} \mathrm{s}\right.$.

- $20+8009^{\circ} \tau$ 。 $20+8009^{\circ} \tau$ 。

- I0+8000.s o tot800s.s 。

- Lo+zoos's 。 totzoos's 。

- I0+8008.9 o T0+8008.9 。

- 0 .

- I-0 I-0

- I-0 I-0

- I-0 I-0

- T0-8000.5 。 $20-8000.5$ 。

- $00+8000^{\circ} \tau$ 。 $00+8000 . \tau$ 。

- $00+8000 . \tau$ 。 $00+8000 . \tau$ 。

- $00+8000 \cdot \tau$ 。 $00+8000 \cdot \tau$ 。

- $00+8000 \cdot \tau$ 。 $00+8000.0$ 。

- z0+800I.s o $00+8000 \cdot 0$ 。

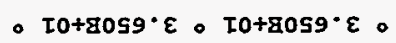

- $20-8000.6$ 。 $20-8000.6$ 。

- $00+8008 \cdot 5$ o $00+8005 \cdot 5$ 。

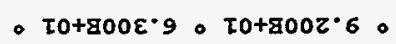

- I0+800z-6 o I0+800Z· 6 。

- $\tau 0+800 z \cdot \tau$ ค $\tau 0+800 z \cdot \tau$ 。

- $z 0+8009^{\circ} I \circ z 0+8009^{\circ} I$ 。

- $00+8000.0$. pasn zous.

- 00+8000.0. pasn zou.

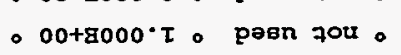

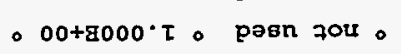

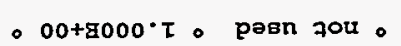

- $00+8000 \cdot \tau$ 。 pasn zou 。

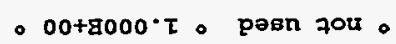

- 00+8000. $\tau$ 。 pesn zou 。

- $00+8000^{\circ} \tau$ 。 pasn zou.

- $00+8000$. I pesn zou 。

- $00+8000^{\circ}$. pesn zou 。

- $00+8000^{\circ} \mathrm{r}$. paen zou 。

- o o

- $00+8000 \cdot \tau$ 。 $00+8000 \cdot \tau$ 。

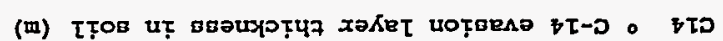

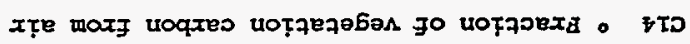

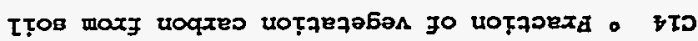

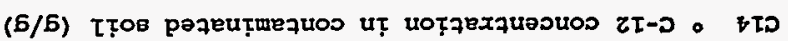

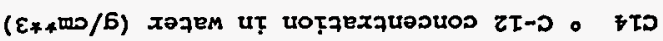

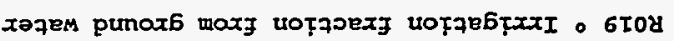

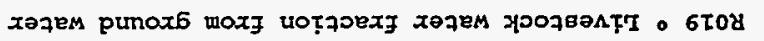

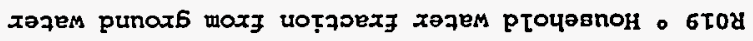

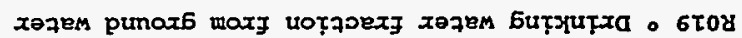

(घ) $8700 x$ 70 y7ded ० 6โ0y

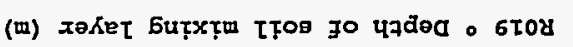

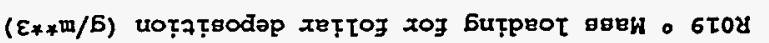

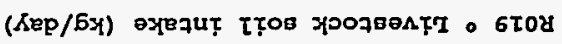

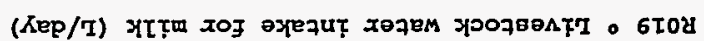

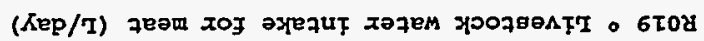

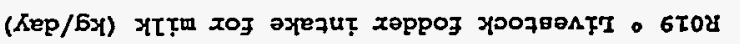

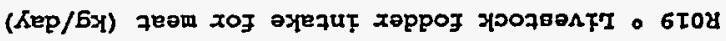

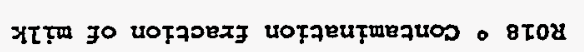

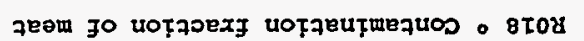

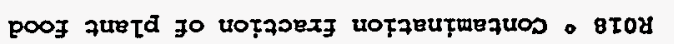

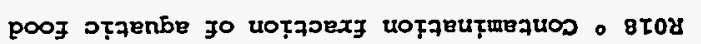

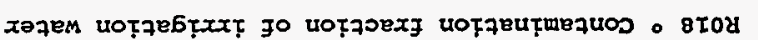

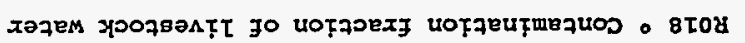

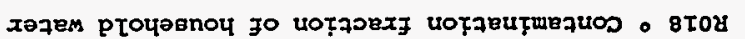

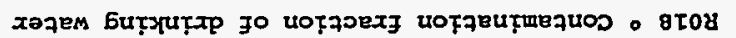

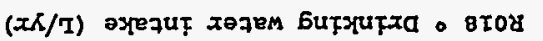

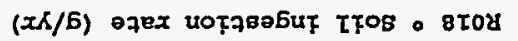

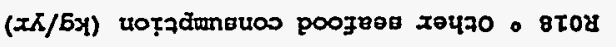

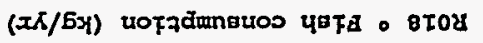

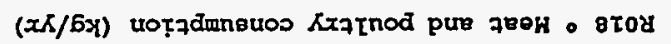

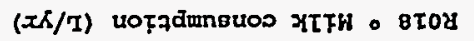

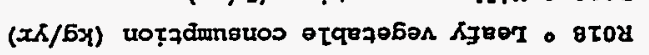

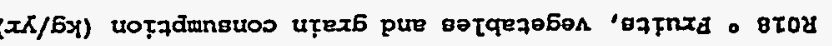
$(G / 90+g \cdot \tau)>=(w)$ snţpex xe[nuue xәzno $(G /$ so+g $\cdot \tau)>=$ (m) sntpex xeqnurue xөano $(G / \nsucceq 0+g \cdot \tau)>=$ (m) snțpex xe[nutue xөzno

$(G / 000 s)>=$ (m) snțpex xe tnutue xəąno $(G / 000 \tau)>=$ (w) snțpex xe tnuure xəano $(G / 00 s)>=$ (m) snțpex xeโnutue xozno $(G / 00 z)>=$ (m) snțpex xe[nưre xezno $(G / 00 \tau)>=$ (m) snțpex xeโnưre xəzno $(G / 0 s)>=$ (m) snțpex xetnuure xąno $(G / 0 z)>=$ (m) snţpex xe tnutue xeano $(G / 0 \tau)>=$ (m) snçpex xeโnưs xөano

$(G / \tau)>=(m)$ entpex $x 8$ Lnure xezno - LTO8 - LTOU - LTo8 - LTor - LTor - Ltor - LTor - LTor - LIO\& - LTO\& - LTor - LTod

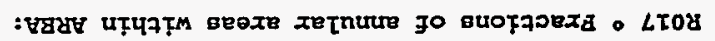

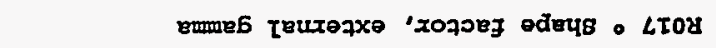

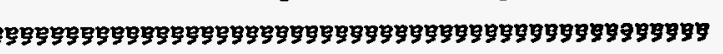

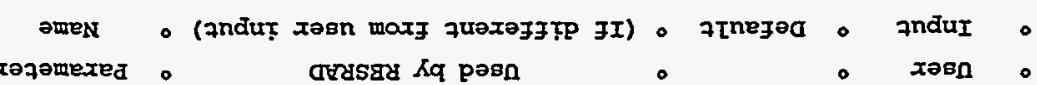

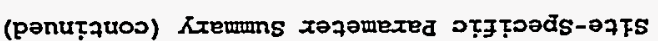

хәдәмехеส

- nuow

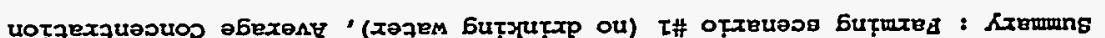

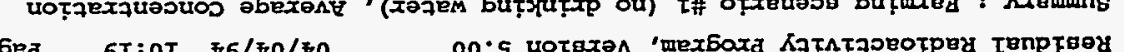


Bummary : Baxming scenario \#1 (no drinking water), Average Concentration

PLIe : RARH1.DAT

Site-Specific Parameter Summary (continued)

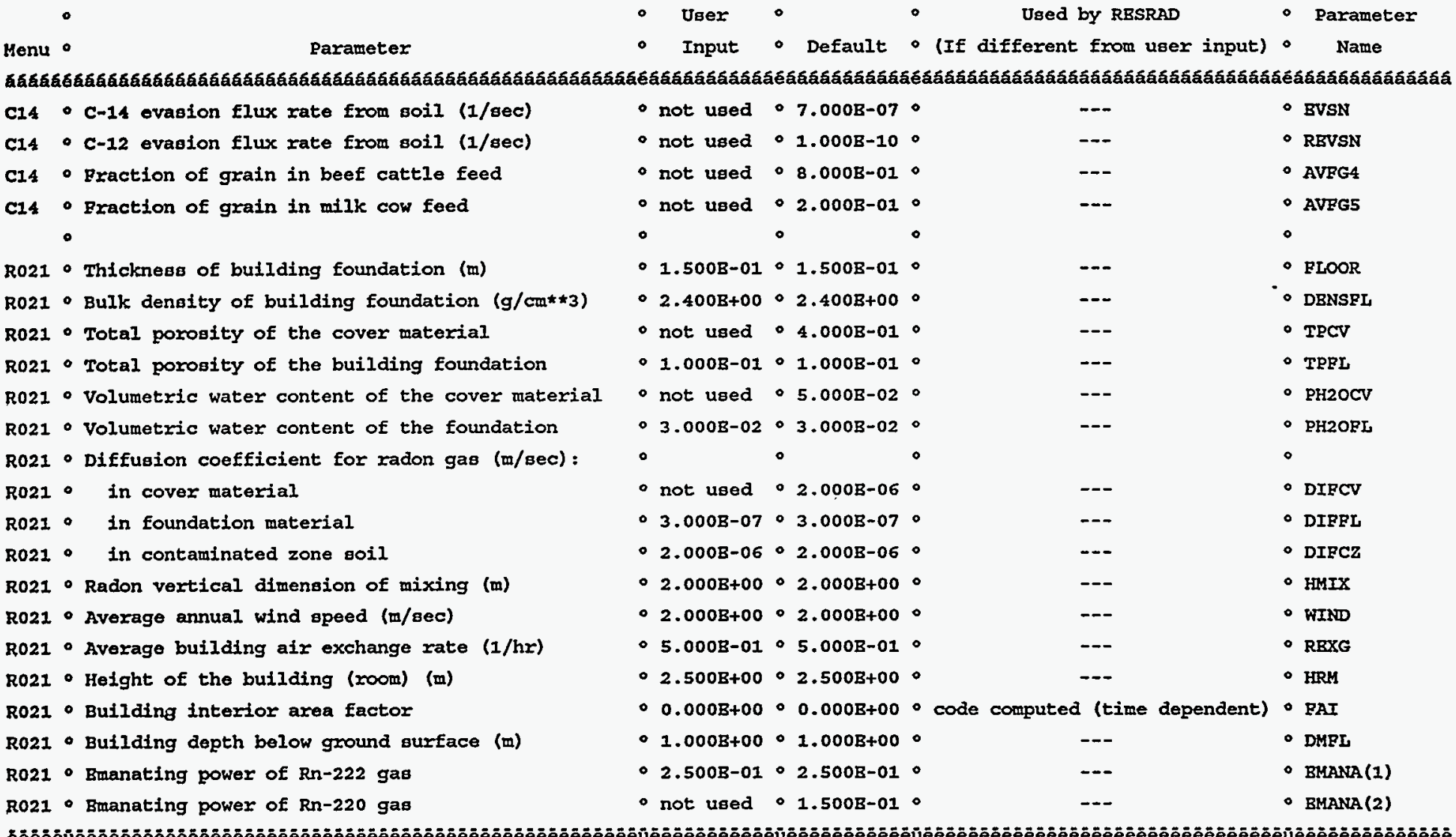

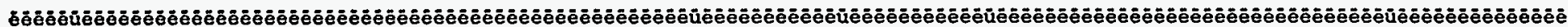

Sumary of pathway selections

\begin{tabular}{|c|c|c|c|}
\hline & Pathway & $\circ$ & $x$ selection \\
\hline át & 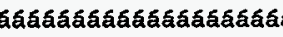 & . & 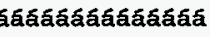 \\
\hline 1 & - external gamma & - & active \\
\hline 2 & -- inhalation (w/o & 10 & active \\
\hline 3 & - plant ingestion & $\bullet$ & active \\
\hline 4 & - meat ingestion & - & active \\
\hline 5 & -- milk ingestion & - & active \\
\hline 6 & - aquatic foods & - & active \\
\hline 7 & -- drinking water & - & active \\
\hline 8 & -- soil ingestion & $\circ$ & active \\
\hline 9 & -- radon & $\circ$ & active \\
\hline
\end{tabular}

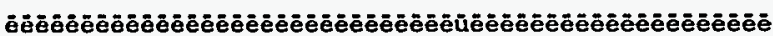


Input data for farming scenario \#1 (off-site drinking water), $35 \mathrm{pCi} / \mathrm{g}$ soil concentration. 


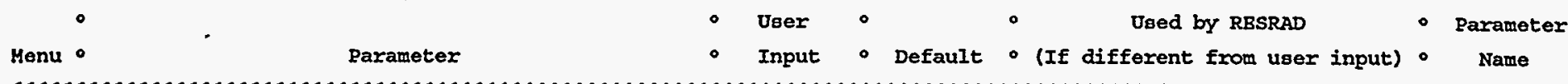

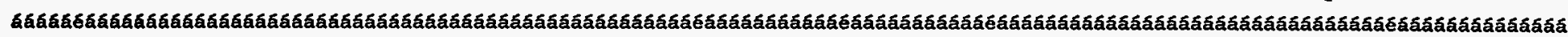

R011 - Area of contaminated zone $(m \neq * 2)$

R011 - Thickness of contaminated zone (m)

R011 - Length paxallel to aquifer flow (m)

R011 - Basic radiation dose limit (mrem/yr)

R011 - Time eince placement of material (yr)

R011 - Times for calculations (yx)

R011 - Times for calculations (yx)

R011 - Times for calculations (yr)

R011 - Times for calculations (yr)

R011 - Times for calculations (yr)

R011 - Times for calculations (yr)

R011 - Times for calculations (yr)

R011 - Times for calculations (yx)

R011 - Times for calculations (yr)

R012 - Initial principal radionuclide (pCi/g):

R012 - Initial principal radionuclide (pci/g):

R012 - Initial principal radionuclide (pCi/g):

R012 - Concentration in groundwater

R012 - Concentration in groundwater

R012 - Concentration in groundwater

(pCi/L): U-234

(pCi/L): $0-235$

(pCi/L): $0-238$

R013 - Cover depth (m)

R013 - Density of cover material ( $g / \mathrm{cm}^{*} * 3$ )

R013 - Cover depth exosion rate $(\mathrm{m} / \mathrm{Yr})$

R013 - Density of contaminated zone $(\mathrm{g} / \mathrm{cm} * * 3)$

R013 - contaminated zone erosion rate $(\mathrm{m} / \mathrm{yr}$ )

R013 - Contaminated zone total porosity

R013 - Contaminated zone effective porosity

R013 - Contaminated zone hydraulic conductivity (m/yx)

R013 - Contaminated zone b parameter

R013 - Humidity in aix ( $g / m * * 3)$

R013 - Bvapotransplration coefficient

R013 - Precipitation $(\mathrm{m} / \mathrm{yx})$

R013 - Irrigation (m/yr)

R013 - Irrigation mode

R013 - Runoff coefficient

R013 - Watershed axea for nearby stream or pond ( $m * * 2)$

R013 - Accuracy for water/soil computations

R014 - Density of saturated zone (g/cm**3)

R014 - Saturated zone total porosity

R014 - saturated zone effective porosity

R014 - saturated zone hydraulic conductivity (m/yx)

R014 - Saturated zone hydraulic gradient

R014 - Saturated zone b parameter

R014 - Hater table drop rate $(\mathrm{m} / \mathrm{y} x)$

R014 - Well pump intake depth ( $m$ below water table)

R014 - Model: Nondispersion (ND) or Mass-Balance (MB)

R014 - Individual's use of groundwatex ( $m * \star 3 / y x)$
- 1.000B+06॰1.000B+04.

- 1.500E-01 $01.000 \mathrm{~B}+00 \circ$

- $1.500 \mathrm{~B}+03 \circ 1.000 \mathrm{~B}+02 \circ$

- $1.000 \mathrm{~B}+02 \circ 3.000 \mathrm{~B}+010$

- $1.500 \mathrm{~B}+01 \bullet 0.000 \mathrm{~B}+00 \circ$

- $1.000 \mathrm{~B}+00 \circ 1.000 \mathrm{~B}+00 \circ$

- 3.000B+00 $03.000 \mathrm{~B}+00 \circ$

- 1.000B+01⒈000B+01。

- 3.000B+01 3.000B+01

- 5.000B+01⒈000B+02。

- $1.000 \mathrm{~B}+02 \cdot 3.000 \mathrm{~B}+02 \circ$

- 3.000B+02 $1.000 \mathrm{~B}+03 \circ$

- 5.000B+02 $03.000 \mathrm{~B}+03 \circ$

- $1.000 \mathrm{~B}+03 \circ 1.000 \mathrm{~B}+04 \circ$

$\circ$

- 1.600B-03 0.000B+00

-7.000B-02 0.000B+00。

- 3.489B+01 0.000B+00。

- not used $0.000 \mathrm{~B}+00$ 。

- not used $0.000 \mathrm{~B}+00 \circ$

- not used $0.000 \mathrm{~B}+00^{\circ}$

-

- $0.000 \mathrm{~B}+00 \circ 0.000 \mathrm{~B}+00 \circ$

- not used $1.500 \mathrm{~B}+00$ 。

- not used $\circ 1.0008-03 \circ$

- $1.500 \mathrm{~B}+00 \circ 1.500 \mathrm{~B}+00 \circ$

- 1.000B-03 $01.000 \mathrm{~B}-03$.

-4.000B-01 4.000B-01。

- 3.000B-01 2.000B-01。

- 1.000B+01⒈000B+01。

- 5.300B+00 $5.3008+00 \circ$

- not used $\circ 8.000 B+00$.

- 6.000B-01 5.000B-01。

- 1.000B+00 $01.000 \mathrm{~B}+00$ 。

- $0.000 \mathrm{~B}+00 \circ 2.000 \mathrm{~B}-01 \circ$

- overhead o overhead 0

- 4.000B-01 2.000B-01。

- $1.000 \mathrm{~B}+06 \circ 1.000 \mathrm{~B}+06$ 。

-1.0008-03 1.0008-03。

$\circ$

- $1.500 \mathrm{~B}+00 \circ 1.500 \mathrm{~B}+\mathrm{CO} \circ$

- 4.000B-01 4.000B-01。

- 3.0008-01 2.000B-01

- $1.000 \mathrm{~B}+02 \circ 1.000 \mathrm{~B}+02 \circ$

- 2.000B-02 $\circ 2.000 \mathrm{~B}-02 \circ$

- 5.300B+00 5.300B+00。

- 1.000B-03 $01.000 \mathrm{~B}-03$ 。

- 1.000B+01०1.000B+01.

- ND $\circ$ ND

- not used $\circ 2.500 \mathrm{~B}+022^{\circ}$

$\circ$

---
---
---
---
---
---

- arka

- THICKO

- LCzPal

- BRTD

- TI

- T( 2)

- $T(3)$

- $T(4)$

- $T(5)$

- $T(6)$

- $T(7)$

- T( 8)

- T( 9)

- $T(10)$

-

- $51(6)$

- $\operatorname{si(7)}$

- $s 1$ ( 8)

- w1 (6)

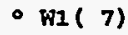

- $\mathrm{H} 1(8)$

$\circ$

- COVBRo

- DBNSCV

- VCV

- DRNSCZ

- VCz

- TPCZ

- BPCZ

- HCCZ

- BCZ

- HUMID

- EVAPTR

- PRBCIP

- RI

- IDITCH

- RUNORE

- WAREA

- BPS

$\circ$

- DBNSAQ

- TPSZ

- BPsz

- HCSz

- HGWT

- BSZ

- VAT

- DWIBFT

- MODBL

- UW 


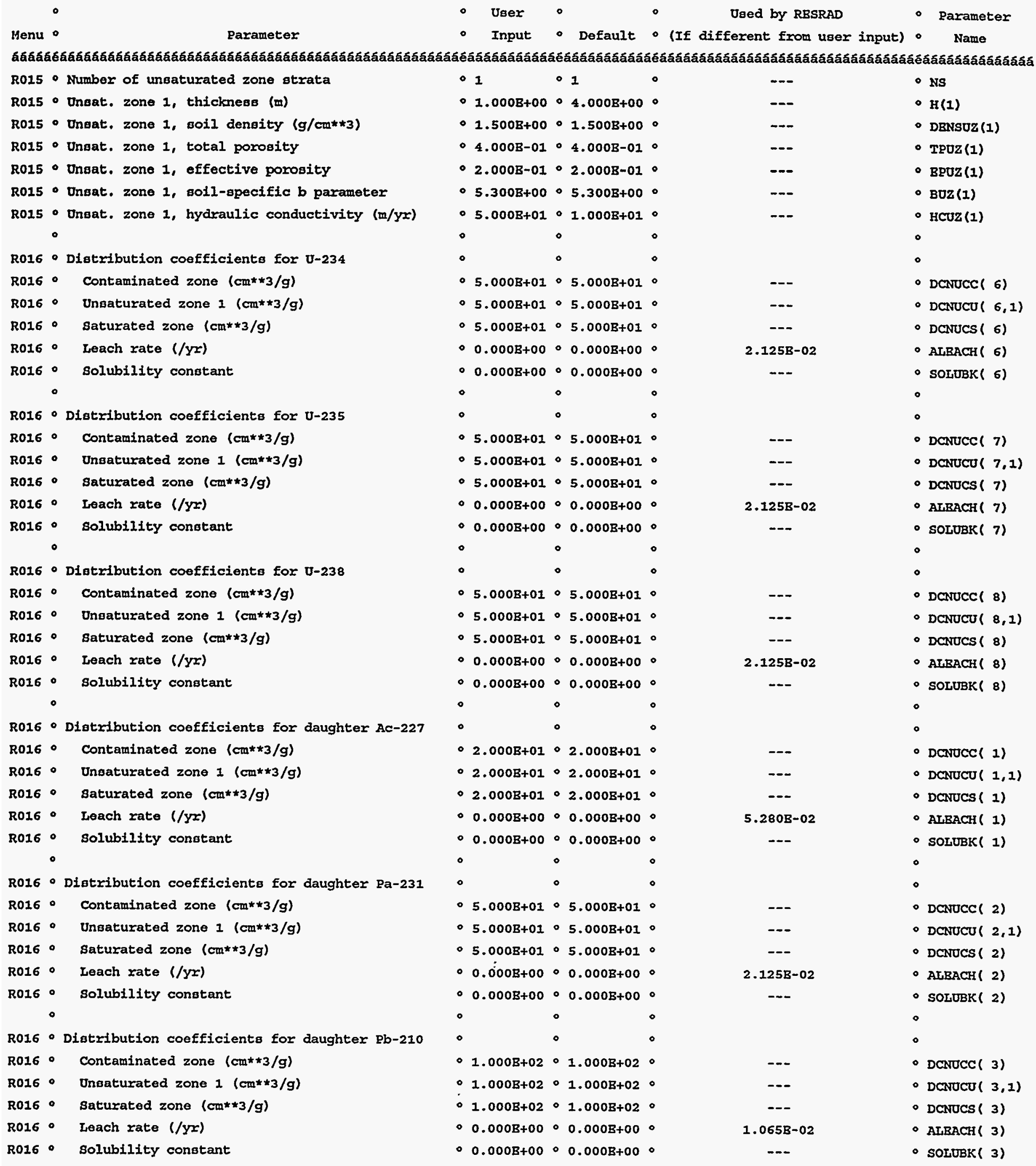




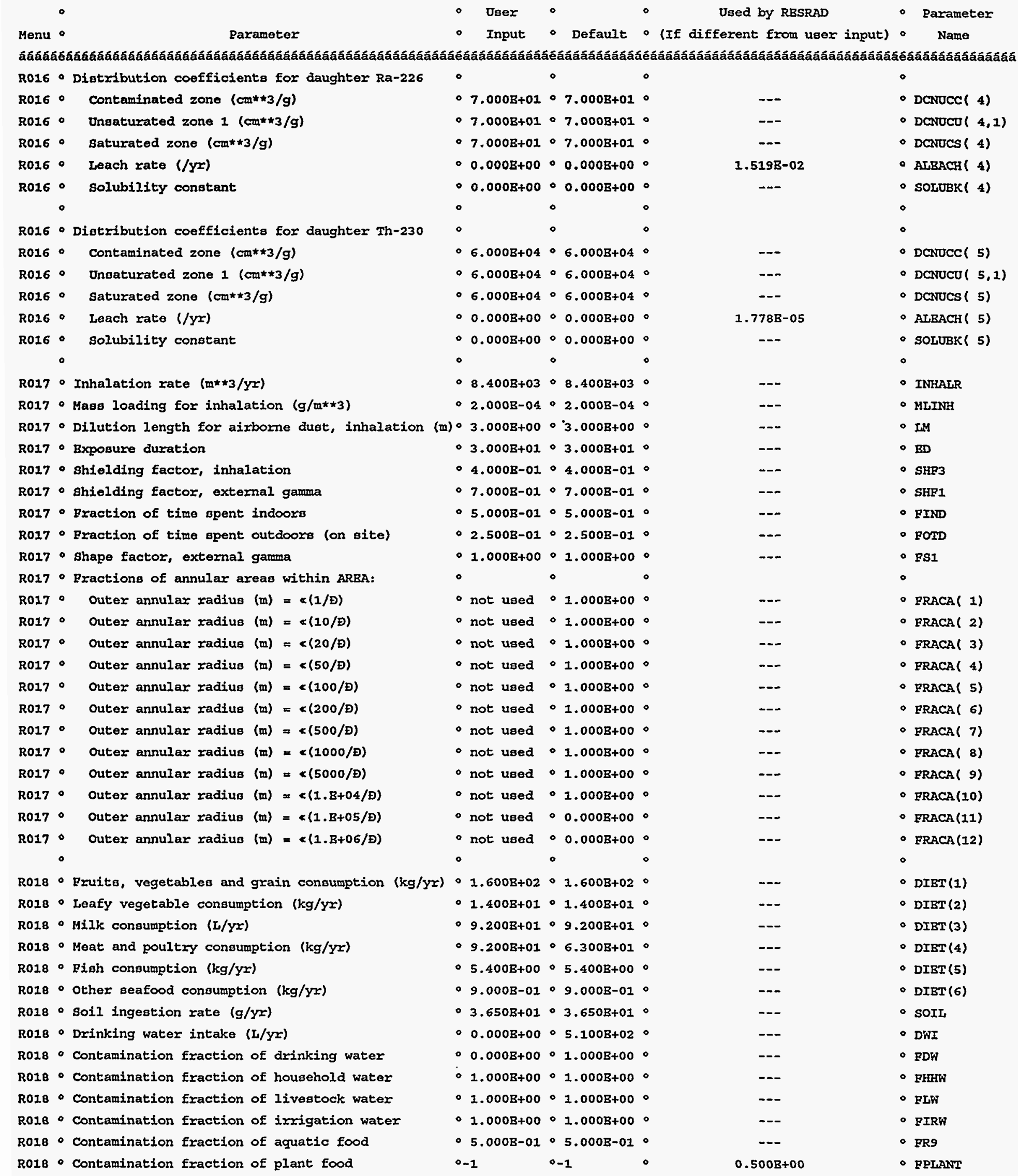


Input data for farming scenario \#2 (on-site drinking water), average soil concentration and 1 pCi/l water concentration. 
Reaidual Radioactivity Program, Veraion 5.00

04/24/94 17:15 Page 4

sumary ,: Farming scenario \#2 (on-site Drinking water), Average Concentration

Pile : EARM2,DAT

Site-Specific Parameter Summary

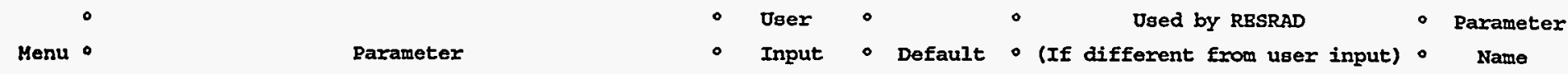

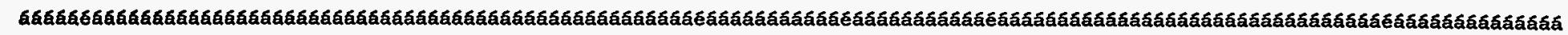

R011 - Area of contaminated zone (m**2)

R011 - Thickness of contaminated zone (m)

R011 - Length parallel to aquifer flow (m)

Ro11 - Basic radiation dose limit (mrem/yr)

R011 Time Bince placement of matexial (yx)

Ro11 Times for calculations (yx)

R011 Times for calculations $(y x)$

R011 - Times for calculations (yx)

R011 - Times for calculations ( $y x)$

R011 - Times for calculations $(y x)$

R011 - Times for calculations ( $y x$ )

R011 - Times for calculations ( $y x)$

R011 - Times for calculations (yx)

R011 - Times for calculations $(y x)$

R012 - Initial pxircipal radionuclide (pci/g): 0-234

R012 - Initial principal radionuclide (pCi/g): 0-238

R012 - Concentration in groundwater (pCi/L): U-234

R012 - concentration in groundwater (pci/L): U-238

\section{$\circ$}

R013 - Cover depth (m)

R013 - Density of cover material ( $/ \mathrm{cm} \star \star 3)$

R013 - Cover depth erosion rate (m/yr)

R013 - Density of contaminated zone $(\mathrm{g} / \mathrm{cm} * * 3)$

R013 - Contaminated zone erosion rate (m/yr)

R013 - Contaminated zone total porosity

R013 - Contaminated zone effective porosity

R013 - Contaminated zone hydraulic conductivity (m/yr)

R013 - Contaminated zone b parametex

R013 - Humidity in air $(\mathrm{g} / \mathrm{m} * * 3)$

R013 - Bvapotranspiration coefficient

R013 - Rrecipitation (m/yx)

R013 - Irxtgation ( $\mathrm{m} / \mathrm{yr}$ )

R013 - Irrigation mode

R013 - Runoff coefficient

R013 - Watershed area for nearby stream ox pond ( $m * \star 2$ )

R013 - Accuracy for water/soil computations

$\circ$

R014 Density of saturated zone $(\mathrm{g} / \mathrm{cm} \star * 3)$

R014 - saturated zone total porosity

R014 - Saturated zone effective porosity

R014 - Saturated zone hydraulic conductivity (m/yx)

R014 - Saturated zone hydraulic gradient

R014 - Saturated zone b parametex

R014 - Water table drop rate (m/yr)

R014 - Well pump intake depth ( $m$ below water table)

R014 Model: Nondiepersion (ND) or MasB-Balance (MB)

R014 Individual's use of groundwater (m**3/yr)

$\circ$

R015 - Number of unsaturated zone strata
- $1.000 \mathrm{~B}+06 \circ 1.000 \mathrm{~B}+04$.

- 1.500B-01 2.000B+00。

- $1.500 \mathrm{~B}+03 \circ 1.000 \mathrm{~B}+02 \circ$

- $1.000 \mathrm{~B}+02 \circ 3.000 \mathrm{~B}+01 \circ$

- $1.500 \mathrm{~B}+01 \circ 0.000 \mathrm{~B}+00$.

- $1.000 \mathrm{~B}+00 \circ 1.000 \mathrm{~B}+00$ 。

- 3.000B+00 $\circ 3.000 \mathrm{~B}+000$

- $1.000 \mathrm{~B}+01 \circ 1.000 \mathrm{~B}+01 \circ$

- 3.000B+01 3.000B+01。

- 5.000B+01 $01.000 \mathrm{~B}+02 \circ$

- $1.000 \mathrm{~B}+02 \cdot 3.000 \mathrm{~B}+02$.

- 3.000B+02 $01.000 \mathrm{~B}+03$ 。

- 5.000B+02 $03.000 \mathrm{~B}+03$ 。

- $1.000 B+03 \circ 1.000 \mathrm{~B}+04 \circ$

$\circ$

-1.610B+00 0.000B+00。

- 6.990B+00 0.000B+00。

- not used $0.000 \mathrm{~B}+00$.

- $1.000 B+00 \cdot 0.000 B+00$ 。

- 0 。

- $0.000 \mathrm{~B}+00 \circ 0.000 \mathrm{~B}+00$.

- not used $1.500 B+00$.

- not used $1.0008-03$.

- $1.500 \mathrm{~B}+00 \circ 1.500 \mathrm{~B}+00$ ○

- 1.000B-03 $1.000 \mathrm{~B}-03 \circ$

-4.000B-01 4.000B-01

- 3.000B-01 2.000B-01 $\circ$

- 1.000B+01 $1.000 \mathrm{~B}+010$

- 5.300B+00 5.300B+00。

- not used $-8.000 \mathrm{~B}+00$ -

- 6.000B-01 5.000B-01

- $1.000 \mathrm{~B}+00$ - $1.000 \mathrm{~B}+00$ 。

- $0.000 \mathrm{~B}+00 \circ 2.000 \mathrm{~B}-01$.

- overhead o overhead $\circ$

- 4.000B-01 2.000B-01。

- $1.000 \mathrm{~B}+06 \circ 1.000 \mathrm{~B}+06^{\circ}$

- $1.000 \mathrm{~B}-03 \circ 1.000 \mathrm{~B}-03 \circ$

0 。

- $1.500 \mathrm{~B}+00 \circ 1.500 \mathrm{~B}+00 \circ$

- 4.000B-01 4.000B-01。

- 3.000B-01 2.000B-01。

- $1.0008+02 \circ 1.000 \mathrm{~B}+02 \circ$

- 2.000B-02 2.000B-02。

- 5.300B+00 $5.300 \mathrm{~B}+00$ 。

- 1.000B-03・1.000B-03。

- $1.000 \mathrm{~B}+01 \circ 1.000 \mathrm{~B}+01$.

- ND ND 0

- not used $\circ 2.500 \mathrm{~B}+02 \circ$

$\circ$

- 1

- 1
--- $\quad$ ARBA

- thicko

- ICZPAQ

- BRID

- TI

- T(2)

- $T(3)$

- T( 4)

- T( 5)

- T( 6)

- T( 7)

- $T(8)$

- T( 9)

- $T(10)$

$\circ$

- S1 (4)

- s1 (5)

- W1 (4)

- $M 1$ ( 5)

$\circ$

- COVBRo

- DENSCV

- VCV

- DBNSCZ

- VCZ

- TPCZ

- BPCZ

- HCCZ

- BCZ

- HUMID

- BVAPTR

- PRBCIP

- RI

- IDITCH

- RUNOFF

- Narba

- BPS

$\circ$

- DENSAQ

- TPSZ

- EPSZ

- HCSZ

- HGWT

- BSZ

- VWT

- DWIBWT

- MODBL

- UW

-

- NS 
sumary : Barming scenario \#2 (on-site Drinking Water), Average Concentration

File : PARM2.DAT

Site-Specific Parameter Summary (continued)

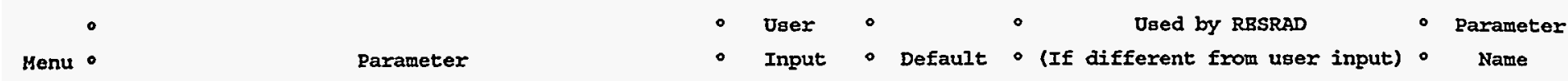

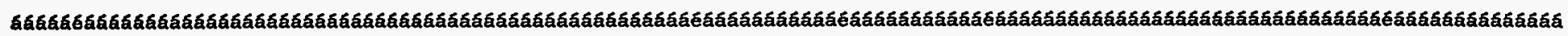

R015 - Unsat, zone 1, thickness (m)

R015 - Unsat, zone 1, soil density (g/cm**3)

R015 - Unsat, zone 1, total porosity

R015 - Onsat. zone 1, effective porosity

R015 - Unsat. zone 1, soil-specific b parameter

R015 - Unoat. zone 1 , hydraulic conductivity ( $\mathrm{m} / \mathrm{yr}$ )

$\circ$

R016 Distribution coefficients for U-234

R016 - Contaminated zone $(\mathrm{cm} \star * 3 / \mathrm{g})$

R016 Unsaturated zone $1(\mathrm{~cm} * \star 3 / \mathrm{g})$

R016 - Saturated zone $(\mathrm{cm} \star 3 / \mathrm{g})$

R016 - Leach rate $(/ \mathrm{y} x)$

R016 - Solubility constant

R016 Distribution coefficients for $0-238$

R016 - Contaminated zone $(\mathrm{cm} * * 3 / \mathrm{g})$

R016 - Unsaturated zone $1(\mathrm{~cm} * * 3 / \mathrm{g})$

R016 - Saturated zone $(\mathrm{cm} * * 3 / \mathrm{g})$

R016 Leach rate $(/ \mathrm{yr})$

R016 - Solubility constant

R016 Diotribution coefficients for daughter $\mathrm{pb}-210$

R016 - Contaminated zone $(\mathrm{cm} * * 3 / \mathrm{g})$

R016 Ongaturated zone $1(\mathrm{~cm} * * 3 / \mathrm{g})$

R016 - Saturated zone $(\mathrm{cm} \star \star 3 / \mathrm{g})$

R016 - Leach rate (/yr)

R016 Solubility constant

R016 Distribution coefficients for daughter Ra-226

R016 - Contaminated zone $(\mathrm{cm} * * 3 / \mathrm{g})$

R016 - Unsaturated zone $1(\mathrm{~cm} * * 3 / g)$

R016 - Saturated zone $(\mathrm{cm} * \star 3 / \mathrm{g})$

R016 - Leach rate (/Yr)

R016 - solubility constant

R016 - Distribution coefficients for daughter Th-230

R016 - Contaminated zone $(\mathrm{cm} * * 3 / \mathrm{g})$

R016 - Unsaturated zone $1(\mathrm{~cm} \star \star 3 / \mathrm{g})$

R016 - saturated zone $(\mathrm{cm} * * 3 / \mathrm{g})$

R016 - Leach rate $(/ y x)$

R016 - Solubility constant

R017 - Inhalation rate $(m * * 3 / y x)$

R017 - Mass loading for inhalation $(\mathrm{g} / \mathrm{m} * * 3)$

R017 - Dilution length for airborne dust, inhalation

R017 - Bxposure duration

R017 - shielding factor, inhalation

R017 - shielding factor, external gamma

R017 - Fxaction of time spent indoors

R017 - Eraction of time spent outdoors (on site)

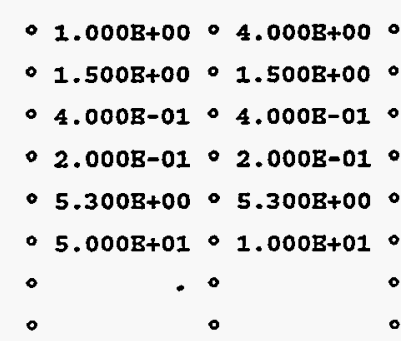

- 5.000B+01 $0.000 \mathrm{~B}+01$ 。

- 5.000B+01 0 5.000B+01。

- 5.000B+01⒌000B+01。

- $0.000 B+00 \circ 0.000 \mathrm{~B}+00$ 。

- $0.000 \mathrm{~B}+00 \circ 0.000 \mathrm{~B}+00^{\circ}$

$\begin{array}{lll}\circ & \circ & 0 \\ 0 & 0 & 0\end{array}$

- 5.000B+01 5.000B+01

- 5.000B+01 5.000B+01

- 5.000B+01 5.000B+01。

- $0.000 \mathrm{~B}+00 \circ 0.000 \mathrm{~B}+00 \circ$

- $0.000 \mathrm{~B}+00 \circ 0.000 \mathrm{~B}+00$ 。

$\circ$

-

- $1.000 \mathrm{~B}+02 \circ 1.000 \mathrm{~B}+02$.

- $1.000 \mathrm{~B}+02 \circ 1.000 \mathrm{~B}+02$.

- $1.000 \mathrm{~B}+02 \circ 1.000 \mathrm{~B}+02$.

- $0.000 B+00 \circ 0.000 B+00 \circ$

- $0.000 B+00 \cdot 0.000 B+00 \circ$

$\circ$

$\circ$

- 7.000B+01 $07.000 \mathrm{~B}+01$ 。

-7.000B+01 7.000B+01.

-7.000B+01⒎000B+01。

- $0.000 B+00 \circ 0.000 B+00 \circ$

$\circ 0.000 B+00 \circ 0.000 B+00 \circ$

- 0 。

- 6.000B+04⒍000B+04.

- 6.000B+04 $0.000 \mathrm{~B}+04$.

- 6.000B+04 $6.000 \mathrm{~B}+04 \circ$

- $0.000 \mathrm{~B}+00 \circ 0.000 \mathrm{~B}+00$.

- $0.000 B+00 \cdot 0.000 B+00$.

$\circ$

- $8.400 \mathrm{~B}+03 \circ 8.400 \mathrm{~B}+03 \circ$

- 2.000B-04 2.000B-04。

m) $03.000 \mathrm{~B}+00 \circ 3.000 \mathrm{~B}+00 \circ$

- 3.000B+01 3.000B+01

-4.000B-01 4.000B-01。

-7.000B-01 7.000B-01

- 5.000B-01 5.000B-01

-2.500B-01 $2.500 \mathrm{~B}-01$.

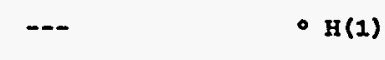

$-$

- DBNSUZ (1)

- Tpuz (1)

- BPUZ(1)

- Buz(1)

- HCUZ(1)

-

-

- $\operatorname{DCNuCC}(4)$

- $\operatorname{DanuCU}(4,1)$

- DCNUCS (4)

- AuBAch (4)

- sorubke (4)

2.125B-02

$-\cdots$

$4.618 \mathrm{~B}+00$

$4.618 \mathrm{~B}+00$

$4.618 \mathrm{~B}+00$

2.213B-01

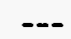

$-\cdots$

$\cdots$

1. 065B-02
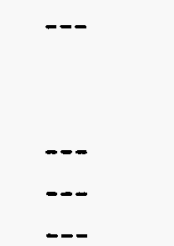

1.519B-02

-

$--$

$--$

$--$

1.778B-05

--

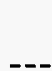

$--$

$\ldots$

$-$

$---$

$---$

$--$
- DCNucc( 5)

- DCanucu (5,1)

- Denucs ( 5)

- arrach (5)

- sorubK( 5)

-

$\circ$

- DCNuCC( 1$)$

- $\operatorname{DCNucu}(1,1)$

- Danucs (1)

- ALBACH ( 1)

- SOLUBK( 1)

-

- DCNUCC( 2 )

- $\operatorname{DCNuCU}(2,1)$

- DCNuCs ( 2)

- ArBach ( 2)

- $\operatorname{somubK}(2)$

$\circ$

-

- $\operatorname{DCNuCC}(3)$

- $\operatorname{DCNuCU}(3,1)$

- DanuCs (3)

- ALBACH ( 3 )

- $\operatorname{soldBK}(3)$

-

- inharR

- MLINH

- LM

- BD

- SHF3

- SHF1

- EIND

- FOTD 


\begin{tabular}{|c|c|c|c|c|c|}
\hline Menu & Parameter & $\begin{array}{ll}- & \text { Usex } \\
- & \text { Input }\end{array}$ & Default & $\begin{array}{l}\text { - } \quad \text { Osed by RBSRAD } \\
\text { - (If different from user input) }\end{array}$ & $\begin{array}{l}\text { - } \quad \text { Parameter } \\
\text { - } \quad \text { Name }\end{array}$ \\
\hline ááá & 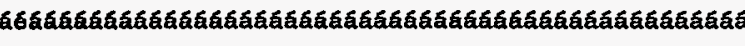 & 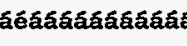 & 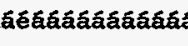 & 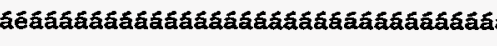 & 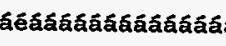 \\
\hline C14 & - C-14 ovanion flux rate from soil (1/Bec) & - not used & $.7 .000 \mathrm{~B}-07$ & -- & - BVSN \\
\hline C14 & - C-12 evasion flux rate from soil (1/sec) & - not used & - $1.000 \mathrm{~B}-10$ & --- & - RBVSN \\
\hline C14 & - Fraction of grain in beef cattle feed & - not used & $.8 .000 \mathrm{~B}-01$ & -- & - AVRG4 \\
\hline C14 & $\begin{array}{l}\text { - Eraction of grain in milk cow feed } \\
\text { - }\end{array}$ & - not used & . 2.000B-01 & 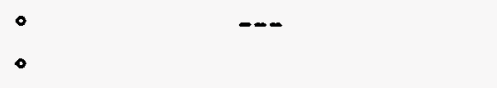 & - AVFG5 \\
\hline R021 & - Thickness of building foundation (m) & - $1.500 \mathrm{~B}-01$ & - $1.500 \mathrm{~B}-01$ & -- & - FLOOR \\
\hline R021 & - Bulk density of building foundation $(\mathrm{g} / \mathrm{cm} * * 3)$ & - $2.400 \mathrm{~B}+00$ & $2.4008+00$ & -- & - DENSEL \\
\hline R021 & - Total porosity of the cover material & - not used & $.4 .0008-01$ & --- & - TPCV \\
\hline R021 & - Total porosity of the building foundation & $.1 .000 \mathrm{~B}-01$ & $01.0008-01$ & --- & $\circ$ TPFL \\
\hline R021 & - volumetric water content of the cover material & not used & - $5.000 \mathrm{~B}-02$ & --- & - $\mathrm{PH} 2 \mathrm{OCV}$ \\
\hline R021 & - Volumetric water content of the foundation & $03.000 \mathrm{~B}-02$ & $.3 .000 \mathrm{~B}-02$ & --- & - PH2OFL \\
\hline R021 & - Diffusion coefficient for radon gas $(\mathrm{m} / \mathrm{Bec})$ : & $\bullet$ & $\circ$ & $\circ$ & $\circ$ \\
\hline R021 & - In cover material & - not used & $.2 .000 \mathrm{~B}-06$ & --- & - DIFCV \\
\hline R021 & - in foundation material & $.3 .0008-07$ & $03.000 \mathrm{~B}-07$ & --- & - DIFRL \\
\hline R021 & - in contaminated zone soil & - $2.000 \mathrm{~B}-06$ & $\circ 2.000 \mathrm{~B}-06$ & --- & - DIFCZ \\
\hline R021 & - Radon vertical dimension of mixing (m) & - $2.000 \mathrm{~B}+00$ & $02.000 \mathrm{~B}+00$ & --- & - HMIX \\
\hline R021 & - Average annual wind speed (m/sec) & $02.000 \mathrm{~B}+00$ & $02.000 \mathrm{~B}+00$ & --- & - MIND \\
\hline R021 & - Average building aix exchange rate $(1 / h x)$ & $05.000 \mathrm{~B}-01$ & - 5.0008-01 & -- & - RBXG \\
\hline Ro21 & - Height of the building (room) (m) & - $2.500 \mathrm{~B}+00$ & - $2.500 \mathrm{~B}+00$ & --- & - HRM \\
\hline R021 & - Building interior area factor & $0.000 \mathrm{~B}+00$ & $0.000 \mathrm{~B}+00$ & - code computed (time dependent) & - $\operatorname{gaI}$ \\
\hline R021 & - Building depth below ground surface (m) & - $1.000 \mathrm{~B}+00$ & $\circ 1.000 \mathrm{~B}+00$ & --- & - DMRE \\
\hline R021 & - Bmanating power of Rn-222 gas & - $2.500 \mathrm{~B}-01$ & $02.500 \mathrm{~B}-01$ & --- & - $\operatorname{BMana}(1)$ \\
\hline R021 & - Bmanating power of Rn-220 gas & - not used & - $1.500 \mathrm{~B}-01$ & --- & - BMANA(2) \\
\hline
\end{tabular}

Summary of Pathway selections

Pathway O User selection

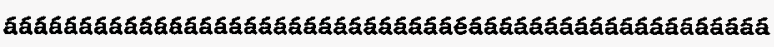

1 -- external gama o active

2 -- inhalation (w/o radon)० active

3 -- plant ingestion $\circ$ active

4 -- meat ingeation active

5 -- milk ingestion $\circ$ active

6 -- aquatic foods 0 active

7 -- drinking water $\circ$ active

8 -- soil ingeation a active

9 -- radon 0 active

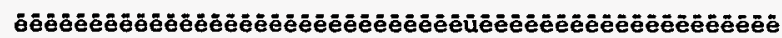


Input data for farming scenario \#2 (on-site drinking water), $35 \mathrm{pCi} / \mathrm{g}$ soil concentration and 1 $\mathrm{pCi} / \mathrm{l}$ water concentration. 
Residual Radioactivity Program, Version 5.00

04/24/94 17:37 Page 6

sumary : Parming acenario \#2 (On-Site Drinking Water), $35 \mathrm{pci} / \mathrm{g}$

pile : gARM235.DAT

Site-specific Parameter summary

\begin{tabular}{|c|c|c|c|c|c|c|}
\hline Menu & Parameter & $\begin{array}{ll}- & \text { User } \\
- & \text { Input }\end{array}$ & Default & $\begin{array}{l}\text { Used } 1 \\
\text { - (If different }\end{array}$ & $\begin{array}{l}\text { by RBSRAD } \\
\text { from user input) }\end{array}$ & $\begin{array}{l}\text { - } \quad \text { Parameter } \\
\text { - } \quad \text { Name }\end{array}$ \\
\hline a.下G & 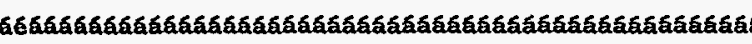 & 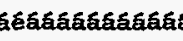 & 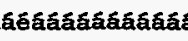 & 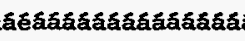 & 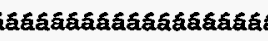 & 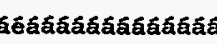 \\
\hline R011 & - Area of contaminated zone $(m * * 2)$ & $01.000 \mathrm{~B}+06$ & - $1.0008+04$ & $\bullet$ & -- & - ARBA \\
\hline Ro11' & - Thickness of contaminated zone (m) & $.1 .5008-01$ & $02.000 \mathrm{~B}+00$ & $\circ$ & --- & - THICko \\
\hline 8011 & - Length parallel to aquifer flow (m) & - $1.500 \mathrm{~B}+03$ & - $1.000 \mathrm{~B}+02$ & $\bullet$ & --- & - LCZPAR \\
\hline R011 & - Basic radiation dose limit (mrem/yx) & $01.000 B+02$ & $03.000 B+01$ & $\circ$ & --- & - BRID \\
\hline Ro11 & - Time since placement of material (yx) & - $1.500 \mathrm{~B}+01$ & $0.000 \mathrm{~B}+00$ & $\bullet$ & -- & - TI \\
\hline 8011 & - Times for calculations $(y x)$ & - $1.000 \mathrm{~B}+00$ & - $1.000 \mathrm{~B}+00$ & $\bullet$ & $-\cdots$ & $\circ T(2)$ \\
\hline R011 & - Times for calculations $(y r)$ & $\circ 3.000 \mathrm{~B}+00$ & $0.000 \mathrm{~B}+00$ & 。 & -- & - $T(3)$ \\
\hline R011 & - Times for calculations $(y r)$ & - $1.0008+01$ & $01.000 \mathrm{~B}+01$ & $\circ$ & -- & - $T(4)$ \\
\hline 8012 & - Times for calculations $(y x)$ & $.3 .0008+01$ & $03.0008+01$ & $\circ$ &.- & - $T(5)$ \\
\hline R011 & - Timas for calculations $(y r)$ & $\circ 5.000 \mathrm{~B}+01$ & $.1 .000 \mathrm{~B}+02$ & $\circ$ & -- & - $T(6)$ \\
\hline R011 & - Times for calculations (yx) & $\circ 1.0008+02$ & $\circ 3.000 \mathrm{~B}+02$ & $\circ$ & --- & $\circ T(7)$ \\
\hline R011 & - Times for calculations $(y x)$ & $.3 .0008+02$ & - $1.0008+03$ & $\bullet$ & $-\cdots$ & - $T(8)$ \\
\hline R011 & - Times for calculations (yx) & $0.000 \mathrm{~B}+02$ & $03.000 \mathrm{~B}+03$ & $\circ$ & --- & $\circ T(9)$ \\
\hline R011 & $\begin{array}{l}\text { - Times for calculations }(y x) \\
\text { - }\end{array}$ & - $1.0008+03$ & $\begin{array}{l}-1.000 \mathrm{~B}+04 \\
-\end{array}$ & $\stackrel{\circ}{\circ}$ & -- & - $T(10)$ \\
\hline R012 & - Initial principal radionuclide (pci/g): $0-234$ & $\circ 1.600 \mathrm{~B}-03$ & $0.000 \mathrm{~B}+00$ & $\circ$ & --- & - $s 1(6)$ \\
\hline R.012 & - Initial principal radionuclide (pCi/g): 0-235 & $.7 .0008-02$ & $0.0008+00$ & $\bullet$ & -- & - $s 1(7)$ \\
\hline R012 & - Initial principal radionuclide (pCi/g): 0-238 & $03.4898+01$ & $0.000 \mathrm{~B}+00$ & $\bullet$ & --- & - $s 1(8)$ \\
\hline R012 & - concentration in groundwater (pci/L): 0-234 & - not used & $0.000 \mathrm{~B}+00$ & $\circ$ & --- & - พ1 ( 6) \\
\hline R012 & - concentration in groundwater (pCi/L): $0-235$ & - not used & $0.0008+00$ & $\circ$ & --- & - พ1( 7) \\
\hline R012 & $\begin{array}{l}\text { - Concentration in groundwater } \\
\text { - }\end{array}$ & $\begin{array}{l}-1.000 B+00 \\
-\end{array}$ & $\begin{array}{l}-0.0008+00 \\
-\end{array}$ & $\stackrel{\circ}{\circ}$ & --- & $\begin{array}{l}-11(8) \\
0\end{array}$ \\
\hline $\mathbf{R 0 1 3}$ & - Cover depth (m) & $\circ 0.000 \mathrm{~B}+00$ & $0.000 \mathrm{~B}+00$ & $\bullet$ & --- & - COVBRO \\
\hline R013 & - Density of cover material $(\mathrm{g} / \mathrm{cm} * \star 3)$ & - not used & $\circ 1.500 \mathrm{~B}+00$ & $\circ$ & --- & - DBNSCV \\
\hline R013 & - Cover depth exosion rate $(m / y r)$ & - not uged & $.1 .000 \mathrm{~B}-03$ & $\bullet$ & -- & - ver \\
\hline R013 & - Denaity of contaminated zone $(\mathrm{g} / \mathrm{cm} \star \star 3)$ & $\circ 1.500 \mathrm{~B}+00$ & - $1.500 \mathrm{~B}+00$ & $\circ$ & --- & - DZNSCZ \\
\hline R013 & - Contaminated zone erosion rate $(m / y x)$ & $01.0008-03$ & $0.0008-03$ & $\circ$ & --- & - vcz \\
\hline R013 & - Contaminated zone total porosity & $\circ 4.000 \mathrm{~B}-01$ & $04.0008-01$ & $\bullet$ & -- & - TPCZ \\
\hline R013 & - Contaminated zone effective porosity & $.3 .000 \mathrm{~B}-01$ & $.2 .000 \mathrm{~B}-01$ & $\circ$ & -- & - BPCZ \\
\hline R013 & - Contaminated zone hydraulic conductivity (m/yr) & $01.000 \mathrm{~B}+01$ & - $1.0008+01$ & $\bullet$ & --- & - HCC2 \\
\hline $\mathbf{R 0 1 3}$ & - contaminated zone b parameter & - $5.300 \mathrm{~B}+00$ & - $5.3008+00$ & $\bullet$ & -- & - $\mathrm{BCZ}$ \\
\hline R013 & - Humidity in air $(g / m * * 3)$ & - not used & $.8 .000 \mathrm{~B}+00$ & $\circ$ & $\cdots$ & - HOMID \\
\hline R013 & - Bvapotranspiration coefficient & - $6.0008-01$ & - 5.000B-01 & $\bullet$ & --- & - BVAPTR \\
\hline R013 & - Precipitation ( $\mathrm{m} / \mathrm{yr})$ & - $1.000 B+00$ & - $1.000 B+00$ & 。 & --- & - PRBCIP \\
\hline R013 & - Irrigation $(m / y x)$ & $\circ 0.000 \mathrm{~B}+00$ & $.2 .0008-01$ & $\bullet$ & $\cdots$ & - RI \\
\hline R013 & - Irrigation mode & - overhead & - overhead & $\circ$ & --- & - IDITCH \\
\hline R013 & - Runoff coofficient & $.4 .000 \mathrm{~B}-01$ & $.2 .000 \mathrm{~B}-01$ & $\circ$ & --- & - RUNORE \\
\hline R013 & - Waterahed area for nearby stream or pond ( $m * * 2$ ) & $.1 .000 B+06$ & $.1 .000 \mathrm{~B}+06$ & $\circ$ & -- & - NARBA \\
\hline R013 & $\begin{array}{l}\text { - Accuracy for water/soil computations } \\
\text { - }\end{array}$ & - $1.000 \mathrm{~B}-03$ & . $1.000 \mathrm{~B}-03$ & ० & --- & $\begin{array}{l}- \text { BPS } \\
\circ\end{array}$ \\
\hline R014 & - Density of saturated zone $(g / c m \star \star 3)$ & - $1.500 \mathrm{~B}+00$ & $\circ 1.500 \mathrm{~B}+00$ & $\bullet$ & -- & - DBNSAQ \\
\hline R014 & - Saturated zone total porosity & $.4 .000 \mathrm{~B}-01$ & . $4.000 \mathrm{~B}-01$ & $\circ$ & --- & - TPSZ \\
\hline R014 & - saturated zone effective porosity & $.3 .0008-01$ & $02.000 \mathrm{~B}-01$ & $\circ$ &.-- & - BPSZ \\
\hline R014 & - Saturated zone hydraulic conductivity $(\mathrm{m} / \mathrm{yx})$ & $.1 .000 \mathrm{~B}+02$ & $.1 .000 \mathrm{~B}+02$ & $\circ$ & $\cdots$ & - HCsz \\
\hline R014 & - saturated zone hydraulic gradient & $.2 .000 \mathrm{~B}-02$ & $\circ 2.000 \mathrm{~B}-02$ & $\circ$ & --- & - HGWT \\
\hline R014 & - saturated zone b parameter & $\circ 5.300 \mathrm{~B}+00$ & $\circ 5.300 \mathrm{~B}+00$ & $\circ$ & --- & - BSz \\
\hline R014 & - Water table arop rate $(m / y x)$ & - $1.000 \mathrm{~B}-03$ & $\circ 1.000 \mathrm{E}-03$ & $\bullet$ & --- & - VWr \\
\hline R014 & - Well pump intake depth (m below watex table) & $\circ 1.0008+01$ & $\circ 1.0008+01$ & $\circ$ & $-\cdots$ & - DพIBWT \\
\hline R014 & - Model: Nondispersion (ND) or Mass-Balance (MB) & - ND & $\circ \mathrm{ND}$ & $\circ$ & --- & - MODBL \\
\hline R014 & - Individual's use of groundwater $(m * * 3 / y r)$ & - not used & $.2 .500 \mathrm{~B}+02$ & & - & - UW \\
\hline
\end{tabular}




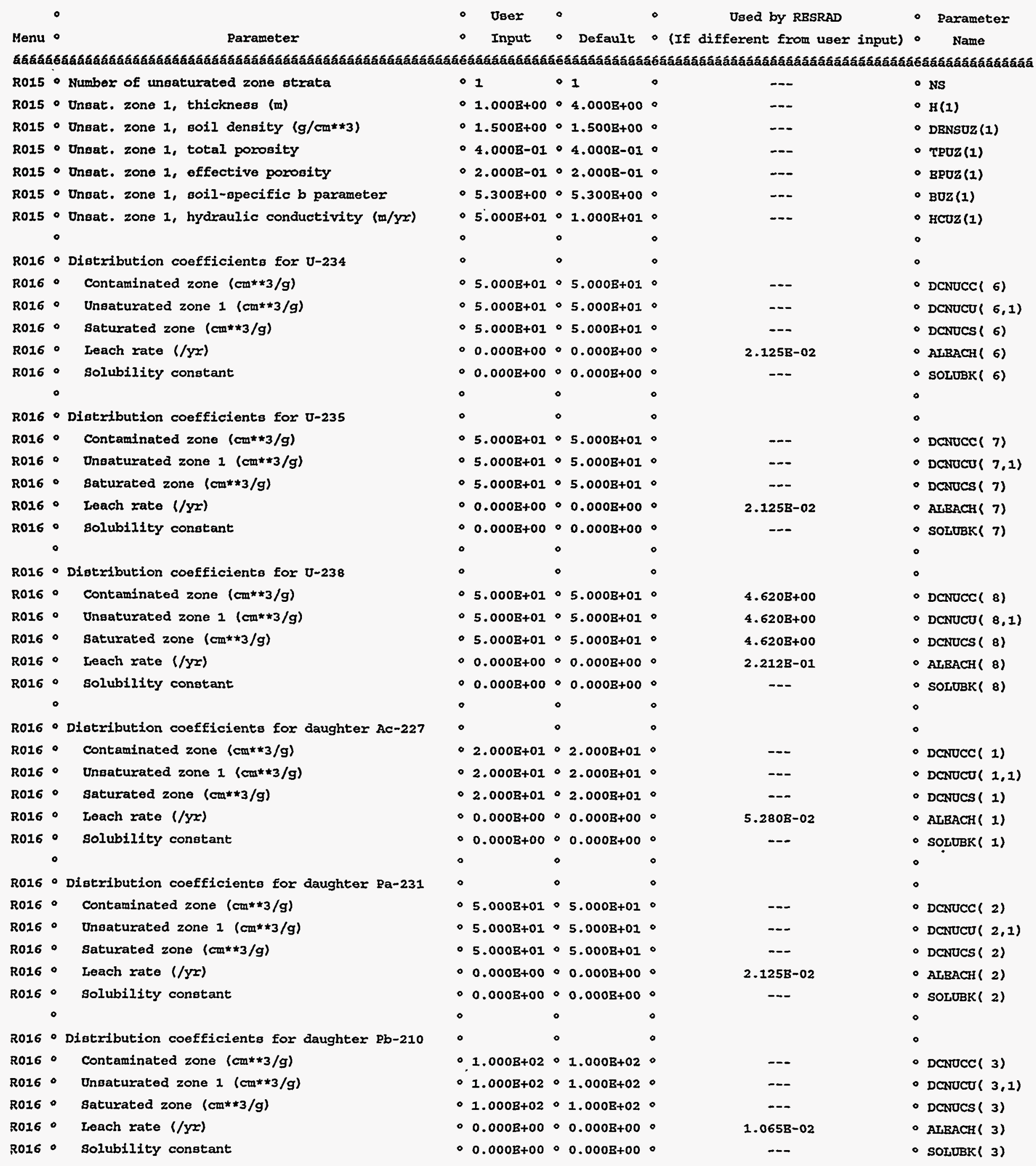


summary : Farming scenaxio \#2 (on-site Drinking Water), $35 \mathrm{pCi} / \mathrm{g}$

File : PARM235.DAT

Site-Specific Parameter Summary (continued)

\begin{tabular}{|c|c|c|c|c|c|c|}
\hline Menu & Parameter & $\begin{array}{ll}- & \text { Oser } \\
- & \text { Input }\end{array}$ & - Default & - & $\begin{array}{l}\text { Used by RBSRAD } \\
\text { (If different from user input) }\end{array}$ & $\begin{array}{l}\text { - Parameter } \\
\text { - Name }\end{array}$ \\
\hline Gak6 & 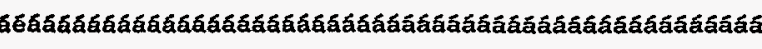 & 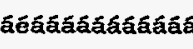 & 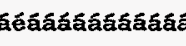 & & 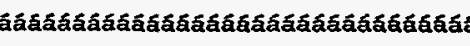 & 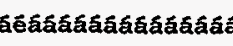 \\
\hline R026 & - Dibtribution coefficients for daughter Ra-226 & $\bullet$ & $\bullet$ & • & & $\circ$ \\
\hline R016 & - Contaminated zone $(\mathrm{cm} * \star 3 / g)$ & $-7.0008+01$ & $\circ 7.0008+01$ & . & -- & - DCNUCC (4) \\
\hline R016 & - Unsaturated zone $1(\mathrm{~cm} * * 3 / \mathrm{g})$ & $.7 .000 B+01$ & - $7.000 \mathrm{~B}+01$ & ० & $-\cdots$ & - DCNUCU (4,1) \\
\hline R016 & - Saturated zone $(\mathrm{cm} * * 3 / g)$ & $07.0008+01$ & $07.0008+01$ & 。 & $\cdots$ & - Danucs (4) \\
\hline R016 & Leach rate $\langle/ y x\rangle$ & $0.0008+00$ & $0.000 \mathrm{~B}+00$ & $\bullet$ & $1.519 \mathrm{~B}-02$ & - ALBACH (4) \\
\hline R016 & - Solubility constant & $\begin{array}{l}-0.000 \mathrm{~B}+00 \\
.\end{array}$ & $\begin{array}{l}-0.0008+00 \\
-\end{array}$ & . & -- & - $\operatorname{soLUBK}(4)$ \\
\hline 8016 & - Distribution coefficients for daughter Th-230 & $\circ$ & - & ○ & & $\circ$ \\
\hline R016 & - Contaminated zone $(\mathrm{cm} * * 3 / \mathrm{g})$ & - $6.000 \mathrm{~B}+04$ & - $6.000 \mathrm{~B}+04$ & 。 & -- & - DCNUCC ( 5) \\
\hline R016 & Unsaturated zone $1(\mathrm{~cm} * * 3 / \mathrm{g})$ & $0.0008+04$ & $.6 .000 \mathrm{~B}+04$ & . & $\cdots$ & - DCNuCU $(5,1)$ \\
\hline R026 & - Saturated zone $(\mathrm{cm} * * 3 / \mathrm{g})$ & - $6.000 \mathrm{~B}+04$ & $.6 .000 \mathrm{~B}+04$ & $\circ$ & --- & - DCNuCs ( 5) \\
\hline R016 & - Leach rate $(/ y x)$ & $0.000 \mathrm{E}+00$ & $0.0008+00$ & $\circ$ & $1.778 \mathrm{~B}-05$ & - ALBACH ( 5) \\
\hline 8026 & - Solubility constant & $\begin{array}{l}-0.000 \mathrm{~B}+00 \\
.\end{array}$ & $\begin{array}{l}-0.0008+00 \\
.\end{array}$ & $\circ$ & $\cdots$ & - SOLUBK( 5) \\
\hline R017 & - Inhalation rate $(m * * 3 / y x)$ & - $8.400 \mathrm{~B}+03$ & - $8.4008+03$ & $\circ$ & $\cdots$ & - inhalar \\
\hline R017 & - Mass loading for inhalation $(g / m \star * 3)$ & $.2 .0008-04$ & $.2 .000 B-04$ & ० & --- & - MLINH \\
\hline R017 & - Dilution length for airborne dust, inhalation (m & $1.000 \mathrm{~B}+00$ & $.3 .0008+00$ & $\circ$ & --- & - LM \\
\hline R017 & - Bxposure duration & - $3.000 \mathrm{~B}+01$ & $.3 .000 \mathrm{~B}+01$ & $\bullet$ & -- & - $\mathrm{BD}$ \\
\hline R017 & - shlelding factor, inhalation & $04.000 \mathrm{~B}-01$ & $.4 .0008-01$ & $\circ$ & -- & - SHF3 \\
\hline R017 & - Shielding factor, external gamma & $.7 .000 \mathrm{~B}-01$ & $.7 .0008-01$ & $\circ$ & --- & - SHF1 \\
\hline R017 & - Braction of time spent indoors & - $5.0008-01$ & $.5 .0008-01$ & 。 & -- & - BIND \\
\hline R017 & - Fraction of time spent outdoors (on site) & $02.500 \mathrm{~B}-01$ & - $2.500 \mathrm{~B}-01$ & - & -. & - EOTD \\
\hline R017 & - Shape factor, external gama & $.1 .000 \mathrm{~B}+00$ & $.1 .000 \mathrm{~B}+00$ & $\bullet$ & --- & - PS1 \\
\hline R017 & - Exactions of annular areas within AREA; & - & $\cdot$ & - & & $\circ$ \\
\hline R017 & - outex annulax radius $(m)=\propto(1 / \theta)$ & - not used & $.1 .000 \mathrm{~B}+00$ & . & -- & - pracar 1) \\
\hline R017 & - Outex annular radius $(m)=\alpha(10 / \theta)$ & - not used & $01.000 B+00$ & $\circ$ & $\cdots$ & - bracal 2) \\
\hline R017 & - Outer annular radius $(\mathrm{m})=\times(20 / \theta)$ & - not used & $.1 .000 \mathrm{~B}+00$ & - & -- & - pracal 3) \\
\hline R017 & - Outer annular radius $(\mathrm{m})=\alpha(50 / \theta)$ & - not used & $.1 .000 \mathrm{~B}+00$ & $\cdot$ & --- & - fRACA (4) \\
\hline 8017 & - Outer annular radius $(m)=\alpha(100 / \theta)$ & - not used & $.1 .000 \mathrm{~B}+00$ & 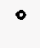 & --- & - ERACAS 5) \\
\hline R017 & outer annular radius $(m)=<(200 / \theta)$ & - not used & $01.000 \mathrm{~B}+00$ & $\circ$ & --- & - pracal 6) \\
\hline R017 & - Outer annulax radius $(\mathrm{m})=\propto(500 / \theta)$ & - not used & $.1 .000 B+00$ & $\bullet$ & -- & - FRACAR 7) \\
\hline R017 & - Outer annular radius $(m)=\alpha(1000 / \boxminus)$ & - not used & - $1.000 \mathrm{~B}+00$ & $\circ$ & -- & - ERACA ( B) \\
\hline R017 & Outer annular radius $(m)=\propto(5000 / D)$ & - not used & - $1.000 \mathrm{~B}+00$ & - & --- & - FRACA (9) \\
\hline 8017 & - Outer annular radius $(m)=<(1.8+04 / D)$ & - not used & $.1 .0008+00$ & $\circ$ & -- & - $\operatorname{RRACA}(10)$ \\
\hline R017 & outex annular radius $(m)=\alpha(1 . B+05 / \boxminus)$ & - not used & $0.0008+00$ & - & -- & - $\operatorname{PRACA}(11)$ \\
\hline R017 & - Outer annular radius $(m)=\alpha(1 . B+06 / B)$ & - not used & $0.000 \mathrm{~B}+00$ & $\stackrel{\circ}{\circ}$ & $\cdots$ & $\begin{array}{l}\text { - PRACA (12) } \\
\text { - }\end{array}$ \\
\hline R018 & - Exuits, vegetables and grain consumption $(\mathrm{kg} / \mathrm{yr})$ & $01.600 \mathrm{~B}+02$ & $.1 .600 \mathrm{~B}+02$ & - & --- & - $\operatorname{DIET}(1)$ \\
\hline २018 & - Leafy vegetable consumption $\langle\mathrm{kg} / \mathrm{yr}\rangle$ & - $1.400 \mathrm{~B}+01$ & $\circ 1.400 B+01$ & $\cdot$ & --- & - DIET (2) \\
\hline 2018 & - Milk consumption (L/Yr) & $0.200 \mathrm{~B}+01$ & $09.200 \mathrm{~B}+01$ & $\bullet$ & -- & - DIBT(3) \\
\hline 3018 & - Meat and poultry consumption $(\mathrm{kg} / \mathrm{yr})$ & $.9 .200 \mathrm{~B}+01$ & - $6.300 \mathrm{~B}+01$ & $\bullet$ & 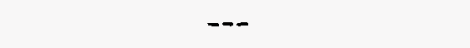 & - $\operatorname{DIBT}(4)$ \\
\hline 3018 & - EiEh consumption (kg/yr) & $\circ 5.4008+00$ & $.5 .400 \mathrm{~B}+00$ & $\bullet$ & $-\cdots$ & - DIBT (5) \\
\hline 018 & - other seafood consumption (kg/yr) & $.9 .000 \mathrm{~B}-01$ & $.9 .000 \mathrm{~B}-01$ & 。 & -- & - DIEI $(6)$ \\
\hline 028 & - Soil ingestion rate $(\mathrm{g} / \mathrm{yr})$ & $03.650 \mathrm{~B}+01$ & $03.650 \mathrm{~B}+01$ & - & -- & - soIL \\
\hline 018 & - Drinking water intake (L/yr) & $.5 .1008+02$ & - $5.100 \mathrm{~B}+02$ & $\circ$ & --- & - DWI \\
\hline 018 & - Contamination fraction of drinking water & $01.0008+00$ & $01.000 \mathrm{~B}+00$ & $\circ$ & $\cdots$ & - $\mathrm{FDW}$ \\
\hline 018 & - Contamination fxaction of household water & $01.0008+00$ & $01.000 \mathrm{~B}+00$ & $\circ$ & -- & - ЕHНW \\
\hline 018 & - Contamination fraction of livestock water & $1.0008+00$ & $1.000 \mathrm{~B}+00$ & $\cdot$ & -- & - BLW \\
\hline 018 & - contamination fraction of imigation watex & $\circ 1.000 \mathrm{~B}+00$ & - $1.000 \mathrm{~B}+00$ & ० & -- & - BIRW \\
\hline 218 & - Contamination fraction of aquatic food & - 5.0008-01 & - $5.000 \mathrm{~B}-01$ & - & --- & - FR9 \\
\hline
\end{tabular}


sumary : Barming scenario \#2 (on-Site Drinking Water), 35 pci/g

Bile : EARM235.DAT

Site-Specific Parameter Sumary (continued)

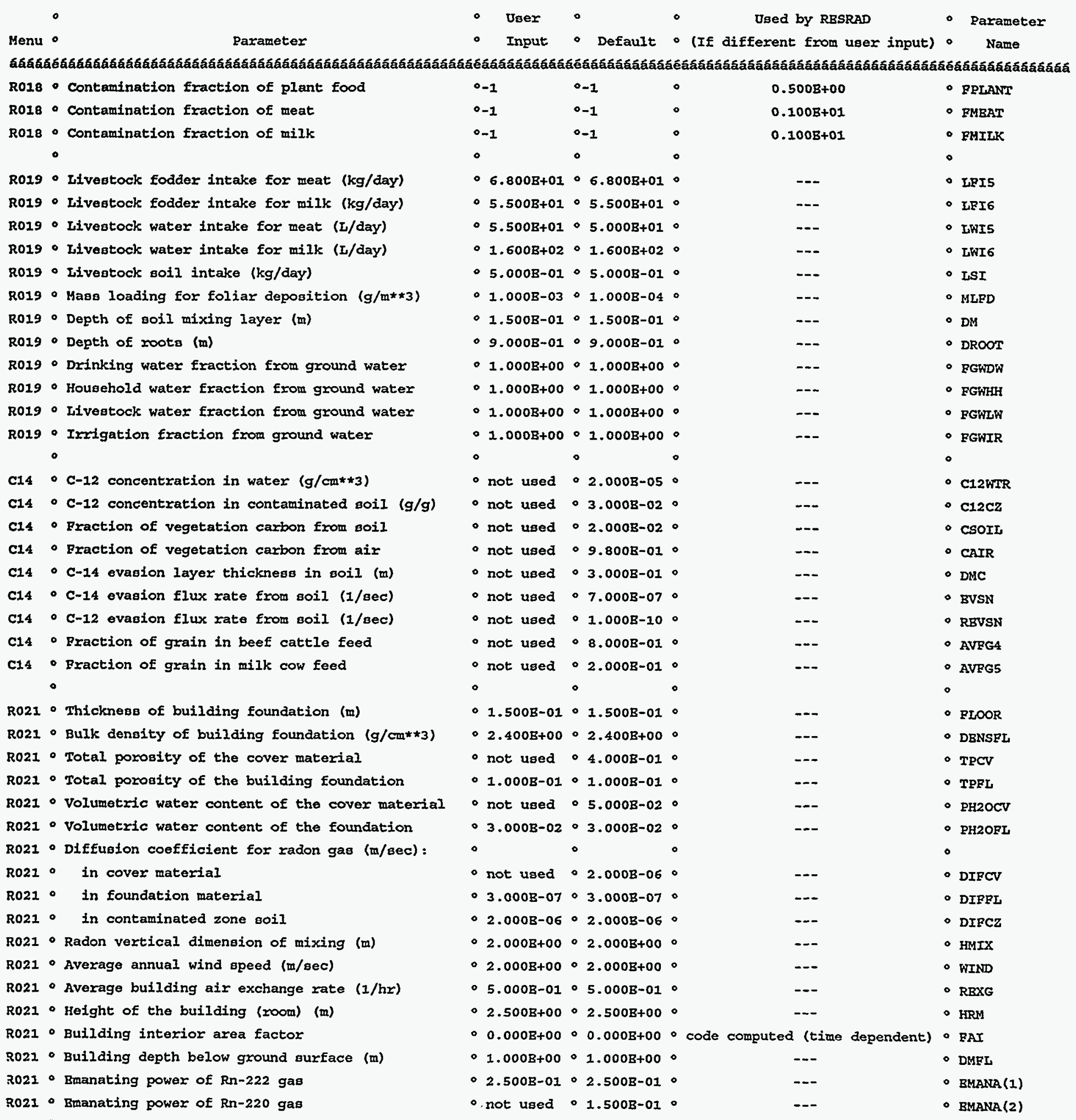

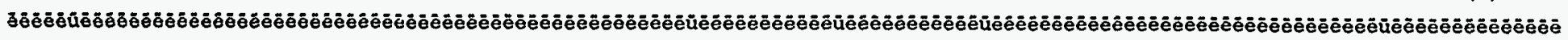

